\title{
Revision and Extension of a Generally Applicable Group-Additivity Method for the Calculation of the Standard Heat of Combustion and Formation of Organic Molecules
}

\author{
Rudolf Naef ${ }^{1, *(D)}$ and William E. Acree, Jr. ${ }^{2}$ (D) \\ 1 Department of Chemistry, University of Basel, 4003 Basel, Switzerland \\ 2 Department of Chemistry, University of North Texas, Denton, TX 76203, USA; acree@unt.edu \\ * Correspondence: rudolf.naef@unibas.ch; Tel.: +41-619-119-273
}

Citation: Naef, R.; Acree, W.E., Jr. Revision and Extension of a Generally Applicable Group-Additivity Method for the Calculation of the Standard Heat of Combustion and Formation of Organic Molecules. Molecules 2021, 26, 6101. https://doi.org/10.3390/ molecules26206101

Academic Editor: Stefano Falcinelli

Received: 15 September 2021

Accepted: 6 October 2021

Published: 10 October 2021

Publisher's Note: MDPI stays neutral with regard to jurisdictional claims in published maps and institutional affiliations.

Copyright: (c) 2021 by the authors. Licensee MDPI, Basel, Switzerland. This article is an open access article distributed under the terms and conditions of the Creative Commons Attribution (CC BY) license (https:/ / creativecommons.org/licenses/by/ $4.0 /)$.

\begin{abstract}
The calculation of the heats of combustion $\Delta \mathrm{H}^{\circ}{ }_{\mathrm{c}}$ and formation $\Delta \mathrm{H}_{\mathrm{f}}^{\circ}$ of organic molecules at standard conditions is presented using a commonly applicable computer algorithm based on the group-additivity method. This work is a continuation and extension of an earlier publication. The method rests on the complete breakdown of the molecules into their constituting atoms, these being further characterized by their immediate neighbor atoms. The group contributions are calculated by means of a fast Gauss-Seidel fitting calculus using the experimental data of 5030 molecules from literature. The applicability of this method has been tested by a subsequent ten-fold crossvalidation procedure, which confirmed the extraordinary accuracy of the prediction of $\Delta \mathrm{H}^{\circ}{ }_{\mathrm{c}}$ with a correlation coefficient $R^{2}$ and a cross-validated correlation coefficient $Q^{2}$ of 1 , a standard deviation $\sigma$ of $18.12 \mathrm{~kJ} / \mathrm{mol}$, a cross-validated standard deviation $\mathrm{S}$ of $19.16 \mathrm{~kJ} / \mathrm{mol}$, and a mean absolute deviation of $0.4 \%$. The heat of formation $\Delta \mathrm{H}^{\circ}{ }_{\mathrm{f}}$ has been calculated from $\Delta \mathrm{H}^{\circ}{ }_{\mathrm{c}}$ using the standard enthalpies of combustion for the elements, yielding a correlation coefficient $\mathrm{R}^{2}$ for $\Delta \mathrm{H}_{\mathrm{f}}^{\circ}$ of 0.9979 and a corresponding standard deviation $\sigma$ of $18.14 \mathrm{~kJ} / \mathrm{mol}$.
\end{abstract}

Keywords: group-additivity method; Gauss-Seidel diagonalization; heat of combustion; heat of formation

\section{Introduction}

The present compilation of data on the heat of combustion and formation of more than 5000 organic molecules and their comparison with theoretical calculations based on a generally applicable atom-groups additivity method is a continuation of theoretical studies on the prediction of various molecular descriptors published in an earlier paper [1]. While this publication primarily focused on the extraordinary versatility of the applied version of the atom-group additivity method for a large number of descriptor predictions, which has been proven by its extension to several further molecular descriptors in subsequent papers [2-6], the present interest rests on the further increase in the trustworthiness of their calculated heats of combustion and formation and their extension to compound classes not yet covered by the earlier paper, particularly the ionic liquids. Previous versions of heat-of-combustion calculations have been based on the additivity of bond energies [7-9], on empirical relations within a series of molecules and their heat of combustion $[10,11]$, on the "heat of atomization" [12], on the combustion value of the electrons in a molecule, corrected for its structural and functional features $[13,14]$, or on the "molecular oxygen balance" [15], all of them outlined in more detail in [1]. An indirect approach to the prediction of the heat of combustion-due to their direct interdependence-is via the calculation of the heat of formation of a molecule, which is either accessible through elaborate quantumtheoretical methods (e.g., [16]) or through a group-additivity method [17,18] similar to the present one. Most of these various approaches have been optimized for a certain class of compounds and are therefore not generally applicable. In contrast, the present 
calculation method is easily extendable and in principle enables the calculation of the heat of combustion and formation of literally any organic molecule under the sun.

\section{Method}

The calculations rest upon a database of at present 34,380 molecules, recorded in their geometry-optimized 3D conformation, encompassing pharmaceuticals, plant protectors, dyes, ionic liquids, liquid crystals, metal-organics, intermediates, and many more, whereinamong many further experimentally determined and calculated molecular descriptors-for 5560 of them, the published experimental combustion and/or formation enthalpies have been stored. In order to avoid structural ambiguity, all six-membered aromatic rings have been defined by six aromatic bonds, in contrast to the more commonly used single-doublebond alternating style. Furthermore, for the same reason, the positive charge in amidinium, pyrazolium, and guanidinium fragments is positioned on the carbon atom between the nitrogen atoms, incidentally in better conformance with the true situation, as shown in, e.g., Figure 1 in [3]. (For the carboxylate or the nitro group, the analogous consideration of charge equilibration is not required within the present atom-group concept, as they are unambiguously defined.) Finally, compounds containing both acidic and basic groups, in particular primary alkylamines (e.g., amino acids) or guanidines (e.g., in creatine or arginine), are treated as zwitter-ionic molecules.

\subsection{Definition of the Atom Groups}

The principle of the breakdown of a molecule into its atom groups in a computerreadable form has been outlined in detail in [1]. Consequently, their naming and meaning are retained in the present work as explained in Table 1 of [1]. However, since then, a number of further atom groups had to be added to the group-contribution parameters set in order to cover the considerable amount of additional, structurally variable molecules. In particular, the inclusion of ordinary salts and ionic liquids required the charged atom groups listed and explained in Table 1, which are interpreted analogously by the computer algorithm as the remaining ones. (Some of these atom groups have already been introduced for the calculation of the liquid viscosity of molecules in [3].)

Table 1. Charged Atom Groups and their Meaning.

\begin{tabular}{|c|c|c|c|c|}
\hline No & Atom Type & Neighbors & Meaning & Example \\
\hline 1 & $\mathrm{~B}(-)$ & $\mathrm{F} 4$ & $\mathrm{BF}_{4}^{-}$ & tetrafluoroborate \\
\hline 2 & $\mathrm{C}(-) \mathrm{sp} 3$ & $\mathrm{C} 3$ & $\mathrm{C}-\mathrm{C}^{-}(\mathrm{C})-\mathrm{C}$ & tricyanomethanide \\
\hline 3 & C sp2 & $\mathrm{NS}=\mathrm{S}(-)$ & $\mathrm{N}-\mathrm{C}(=\mathrm{S})-\mathrm{S}^{-}$ & dithiocarbamate \\
\hline 4 & $\mathrm{C}$ aromatic & $\mathrm{H}: \mathrm{C}: \mathrm{N}(+)$ & $\mathrm{C}: \mathrm{CH}: \mathrm{N}^{+}$ & $\mathrm{C} 2$ in pyridinium \\
\hline 5 & $\mathrm{C}(+)$ aromatic & $\mathrm{H}: \mathrm{N} 2$ & $\mathrm{~N}: \mathrm{C}^{+}(\mathrm{H}): \mathrm{N}$ & C2 in imidazolium \\
\hline 6 & C sp & $\mathrm{C} \# \mathrm{~N}(-)$ & $\mathrm{N \# C- \textrm {C } ^ { - }}$ & tricyanomethanide \\
\hline 7 & C sp & $\mathrm{N \# N(-)}$ & $\mathrm{N \# C-N^{- }}$ & dicyanoamide \\
\hline 8 & C sp & $=\mathrm{N}=\mathrm{S}(-)$ & $\mathrm{N}=\mathrm{C}=\mathrm{S}^{-}$ & Thiocyanate \\
\hline 9 & $\mathrm{~N}(+) \mathrm{sp} 3$ & $\mathrm{C} 4$ & $\mathrm{NC}_{4}^{+}$ & tetraalkylammonium \\
\hline 10 & $\mathrm{~N}(+) \mathrm{sp} 2$ & $\mathrm{O} 2=\mathrm{O}(-)$ & $\mathrm{NO}_{3}^{-}$ & nitrate \\
\hline 11 & $\mathrm{~N}$ aromatic & $\mathrm{C} 2: \mathrm{C}(+)$ & $(\mathrm{C})(\mathrm{C}): \mathrm{C}^{+}$ & N1 in 1-alkylimidazolium \\
\hline 12 & $\mathrm{~N}(+)$ aromatic & $\mathrm{C}: \mathrm{C}(\mathrm{C}): \mathrm{N}^{+}(\mathrm{C}): \mathrm{C}$ & \multicolumn{2}{|c|}{$\mathrm{N}$ in 1-alkylpyridinium } \\
\hline 13 & $\mathrm{~N}(-)$ & $\mathrm{C} 2$ & $\mathrm{C}-\mathrm{N}^{-}-\mathrm{C}$ & dicyanoamide \\
\hline 14 & $\mathrm{~S} 4$ & $\mathrm{O} 2=\mathrm{O} 2(-)$ & $\mathrm{SO}_{4}^{-}$ & hydrosulfate \\
\hline 15 & $\mathrm{~S} 4$ & $\mathrm{CO}=\mathrm{O} 2(-)$ & $\mathrm{C}-\mathrm{SO}^{-}$ & methylsulfonate \\
\hline
\end{tabular}


The atom groups do not take into account the characteristics of the molecules' threedimensional structures, such as intramolecular hydrogen-bridge bonds, intramolecular $\mathrm{H}-\mathrm{H}$ interactions, or ring-strain forces. These effects have summarily been considered by means of the special groups listed and explained in Table 2, wherein the column titles are not to be interpreted literally. With regard to the ring-strain contributions (Angle60, Angle90, and Angle102), caused by forced angle constriction at each ring atom in small rings, it should be stressed that the calculated values inherently also encompass the effect of the compensatory angle widening between the ring atoms and any further atoms attached to them (e.g., the H-C-H and $\mathrm{H}-\mathrm{C}-\mathrm{C}$ angles on cyclopropane). These special groups are treated just like the ordinary atom groups in the calculation of their contribution as well as the subsequent molecular descriptor value.

Table 2. Special Groups and their Meaning.

\begin{tabular}{ccc}
\hline Atom Type & Neighbors & Meaning \\
\hline $\mathrm{H}$ & H Acceptor & Intramolecular H bridge between acidic $\mathrm{H}($ on $\mathrm{O}, \mathrm{N}$ or $\mathrm{S})$ and basic acceptor $(\mathrm{O}, \mathrm{N}$ or $\mathrm{F})$ \\
$\mathrm{H}$ &. $\mathrm{H}$ & at distance $<1.75$ Angstroms \\
$\mathrm{H}$ &.. $\mathrm{H}$ & Intramolecular H-H distance $<2$ Angstroms \\
Angle60 & & Intramolecular H-H distance $2-2.3$ Angstroms \\
Angle90 & & Bond angle $<74$ deg \\
Angle102 & & Bond angle 74-98 deg \\
\hline
\end{tabular}

\subsection{Calculation of the Group Contributions}

The parameter values of the atom and special groups are calculated in four steps, outlined in detail in [1]: the first step creates a temporary compounds list and adds those compounds from the database into it for which the experimental heat of combustion is known. Secondly, for each of the "backbone" atoms (i.e., atoms bound to at least two other direct neighbor atoms) in the molecules, its atom group is defined according to the rules defined in [1], corresponding to the atom type and neighbors' terms listed in Table 4 , and then its occurrence in the molecule is counted. Next, an $\mathrm{M} \times(\mathrm{N}+1)$ matrix is generated, where $M$ is the number of molecules, where $N+1$ is the number of atoms and special groups of Table 4 plus the molecules' experimental heats of combustion, and where each matrix element $(i, j)$ receives the number of occurrences of the $j$ th atomic or special group in the ith molecule. Finally, normalization of this matrix into an Ax = B matrix and its subsequent balancing using a fast Gauss-Seidel calculus [19] yields the group contributions $\mathrm{x}$, which are shown in Table 4 .

\subsection{Calculation of the Standard Heats of Combustion and Formation}

The subsequent calculation of the heat of combustion $\Delta \mathrm{H}^{\circ}$ (c) is a simple summing up of the contributions of the atom groups in a molecule using the values shown in Table 4 , applying Equation (1), wherein $a_{i}$ and $b_{j}$ are the contribution values, $A_{i}$ is the number of occurrences of the $i$ th atom group and $B_{j}$ is the number of occurrences of the special groups.

$$
\Delta \mathrm{H}_{\mathrm{c}}^{\circ}=\Sigma_{\mathrm{i}} \mathrm{a}_{\mathrm{i}^{*}} \mathrm{~A}_{\mathrm{i}}+\Sigma_{\mathrm{j}} \mathrm{b}_{\mathrm{j} *} \mathrm{~B}_{\mathrm{j}}
$$

It is immediately evident that these calculations are limited to compounds for which each atom group contained in it (excluding the special groups) has its corresponding one shown in Table 4. Beyond this, in order to receive reliable results, only "valid" group contributions are to be used, i.e., contributions that have been supported in the groupparameters calculation by at least three independent molecules, i.e., by the number in the rightmost column of Table 4 exceeding 2 . As a consequence, the statistics data at the bottom of Table 4 show that the number of compounds for which finally the heat of combustion is calculated (lines B, C, and D) is smaller than that on which the computation of the complete set of group contributions is based (line A). 
The heat of formation of the molecules is immediately calculated from their heat of combustion by the subtraction of the standard enthalpies of combustion of the elements as given in $[20,21]$.

In Table 3, a simple example may explain the use of Table 4: the experimental heat of combustion of 4-methylene-2-oxetanone (diketene) is - $1913.4 \mathrm{~kJ} / \mathrm{mol}$ [21]. The atom groups and the special group defining this compound are collected in Table 3 and yield a calculated value of $-1903.2 \mathrm{~kJ} / \mathrm{mol}$.

Table 3. Example Calculation of the Standard Heat of Combustion (in kJ/mol) of 4-Methylene-2-oxetanone.

\begin{tabular}{cccccccc}
\hline $\begin{array}{c}\text { Atom Type } \\
\text { Neighbors }\end{array}$ & C sp3 H2C2 & C sp2 H2=C & C sp2 C=CO & C sp2 CO=O & O C2(2pi) & Angle90 & Sum \\
\hline Contribution & -653.47 & -703.3 & -470.12 & -256.51 & 278.25 & -24.51 \\
\hline $\mathrm{n}$ Groups & 1 & 1 & 1 & 1 & 1 & 4 & -1903.19 \\
\hline $\mathrm{N} \times$ Contrib. & -653.47 & -703.3 & -470.12 & -256.51 & 278.25 & -98.04 & -19 \\
\hline
\end{tabular}

\subsection{Cross-Validation Calculations}

The results of the heat-of-combustion data are immediately tested for plausibility using a 10-fold cross-validation algorithm, requiring 10 recalculations that guarantee that each of the complete set of compounds has been used once as a test sample. The corresponding training and test data are added to each of the molecule files, and the respective statistics data are collected at the bottom of Table 4 . Again, due to the $10 \%$ smaller number of training molecules used in the 10 cross-validation calculations, the number of compounds for which the heat of combustion is evaluated as the test value is even smaller (lines E, F, G, and H) than that of the training set (lines B, C, and D). The statistics data of Table 4 also show a significantly lower number of "valid" groups in line A than the total number of atoms and special groups. The residual "invalid" groups, although at present not applicable for heat-of-combustion calculations, have been left in Table 4 for future use in this continuing project. Interested scientists may want to help to increase the number of "valid" groups in this database by molecules carrying the under-represented atom groups. At present, the list of elements for heat-of-combustion calculations is limited to $\mathrm{H}, \mathrm{B}, \mathrm{C}, \mathrm{N}, \mathrm{O}, \mathrm{P}, \mathrm{S}, \mathrm{Si}$, and/or halogen.

Table 4. Atom Groups and their Contributions to $\Delta \mathrm{H}^{\circ}$ (c) Calculations (in $\mathrm{kJ} / \mathrm{mol}$ ).

\begin{tabular}{|c|c|c|c|c|c|}
\hline Entry & Atom Type & Neighbors & Contribution & Occurrences & Molecules \\
\hline 1 & $\mathrm{~B}$ & $\mathrm{C} 3$ & -5771.41 & 10 & 10 \\
\hline 2 & B & $\mathrm{C} 2 \mathrm{O}$ & -5234.3 & 2 & 2 \\
\hline 3 & $\mathrm{~B}(-)$ & $\mathrm{F} 4$ & -128.41 & 1 & 1 \\
\hline 4 & C sp3 & H3В & 927.34 & 3 & 1 \\
\hline 5 & C sp3 & $\mathrm{H} 3 \mathrm{C}$ & -774.53 & 5659 & 2598 \\
\hline 6 & C sp3 & $\mathrm{H} 3 \mathrm{~N}$ & -1273.86 & 288 & 183 \\
\hline 7 & C sp3 & $\mathrm{H} 3 \mathrm{~N}(+)$ & -1258.26 & 22 & 10 \\
\hline 8 & C sp3 & $\mathrm{H} 3 \mathrm{O}$ & -1273.9 & 493 & 333 \\
\hline 9 & C sp3 & H3S & -1435.83 & 36 & 30 \\
\hline 10 & C sp3 & H3P & -1106.35 & 3 & 1 \\
\hline 11 & C sp3 & $\mathrm{H} 3 \mathrm{Si}$ & -1323.2 & 116 & 49 \\
\hline 12 & C sp3 & $\mathrm{H} 2 \mathrm{BC}$ & 1052.3 & 22 & 8 \\
\hline 13 & C sp3 & $\mathrm{H} 2 \mathrm{C} 2$ & -653.47 & 9139 & 2066 \\
\hline 14 & C sp3 & $\mathrm{H} 2 \mathrm{CN}$ & -1150.33 & 632 & 346 \\
\hline
\end{tabular}


Table 4. Cont.

\begin{tabular}{|c|c|c|c|c|c|}
\hline Entry & Atom Type & Neighbors & Contribution & Occurrences & Molecules \\
\hline 15 & C sp3 & $\mathrm{H} 2 \mathrm{CN}(+)$ & -1136.52 & 76 & 51 \\
\hline 16 & C sp3 & $\mathrm{H} 2 \mathrm{CO}$ & -1140.92 & 1209 & 753 \\
\hline 17 & C sp3 & $\mathrm{H} 2 \mathrm{CS}$ & -1313.58 & 180 & 118 \\
\hline 18 & C sp3 & $\mathrm{H} 2 \mathrm{CP}$ & -825.63 & 6 & 3 \\
\hline 19 & C sp3 & $\mathrm{H} 2 \mathrm{CF}$ & -626.92 & 15 & 14 \\
\hline 20 & C sp3 & $\mathrm{H} 2 \mathrm{CCl}$ & -616.8 & 81 & 70 \\
\hline 21 & C sp3 & $\mathrm{H} 2 \mathrm{CBr}$ & -620.8 & 23 & 20 \\
\hline 22 & C sp3 & $\mathrm{H} 2 \mathrm{CJ}$ & -685.85 & 12 & 9 \\
\hline 23 & C sp3 & $\mathrm{H} 2 \mathrm{CSi}$ & -1211.79 & 130 & 51 \\
\hline 24 & C sp3 & $\mathrm{H} 2 \mathrm{~N} 2$ & -1644.62 & 33 & 12 \\
\hline 25 & Csp3 & H2N2(+) & -1666.85 & 6 & 6 \\
\hline 26 & C sp3 & $\mathrm{H} 2 \mathrm{NO}$ & -1630.65 & 8 & 6 \\
\hline 27 & C sp3 & H2NS & -1776.97 & 2 & 1 \\
\hline 28 & C sp3 & H2NS(+) & -1817.73 & 1 & 1 \\
\hline 29 & C sp3 & $\mathrm{H} 2 \mathrm{NP}(+)$ & -565.68 & 1 & 1 \\
\hline 30 & C sp3 & $\mathrm{H} 2 \mathrm{O} 2$ & -1605.49 & 31 & 26 \\
\hline 31 & C sp3 & $\mathrm{H} 2 \mathrm{OSi}$ & -1715.41 & 1 & 1 \\
\hline 32 & C sp3 & $\mathrm{H} 2 \mathrm{OCl}$ & -1115.09 & 4 & 3 \\
\hline 33 & C sp3 & $\mathrm{H} 2 \mathrm{~S} 2$ & -1997.67 & 9 & 7 \\
\hline 34 & C sp3 & HBC2 & 1197 & 6 & 2 \\
\hline 35 & C sp3 & $\mathrm{HC} 3$ & -529.09 & 1386 & 765 \\
\hline 36 & C sp3 & HC2N & -1026.35 & 106 & 84 \\
\hline 37 & C sp3 & $\mathrm{HC} 2 \mathrm{~N}(+)$ & -1004.99 & 43 & 40 \\
\hline 38 & C sp3 & $\mathrm{HC} 2 \mathrm{O}$ & -1010.37 & 545 & 330 \\
\hline 39 & C sp3 & $\mathrm{HC} 2 \mathrm{~S}$ & -1179.91 & 34 & 25 \\
\hline 40 & C sp3 & HC2Si & -1076.92 & 4 & 2 \\
\hline 41 & C sp3 & $\mathrm{HC} 2 \mathrm{~F}$ & -486.29 & 5 & 5 \\
\hline 42 & C sp3 & $\mathrm{HC} 2 \mathrm{Cl}$ & -491.9 & 48 & 32 \\
\hline 43 & C sp3 & $\mathrm{HC} 2 \mathrm{Br}$ & -499.17 & 9 & 7 \\
\hline 44 & C sp3 & HC2J & -574.72 & 4 & 3 \\
\hline 45 & C sp3 & HCN2 & -1514.29 & 5 & 4 \\
\hline 46 & C sp3 & $\mathrm{HCN} 2(+)$ & -1537.23 & 5 & 5 \\
\hline 47 & C sp3 & $\mathrm{HCNO}$ & -1525.32 & 5 & 5 \\
\hline 48 & C sp3 & $\mathrm{HCNO}(+)$ & -1522.69 & 4 & 2 \\
\hline 49 & C sp3 & HCNS & -1683.66 & 4 & 2 \\
\hline 50 & C sp3 & $\mathrm{HCO} 2$ & -1473.47 & 63 & 54 \\
\hline 51 & C sp3 & HCS2 & -1791.66 & 1 & 1 \\
\hline 52 & C sp3 & HCF2 & -447.7 & 14 & 13 \\
\hline 53 & C sp3 & $\mathrm{HCFCl}$ & -470.21 & 4 & 4 \\
\hline 54 & C sp3 & $\mathrm{HCCl} 2$ & -494.97 & 18 & 17 \\
\hline 55 & C sp3 & $\mathrm{HCClBr}$ & -510.39 & 1 & 1 \\
\hline
\end{tabular}


Table 4. Cont.

\begin{tabular}{|c|c|c|c|c|c|}
\hline Entry & Atom Type & Neighbors & Contribution & Occurrences & Molecules \\
\hline 56 & C sp3 & HCBr2 & -475.67 & 1 & 1 \\
\hline 57 & C sp3 & HN3(+) & -2166.08 & 1 & 1 \\
\hline 58 & C sp3 & HNO2 & -1989.17 & 1 & 1 \\
\hline 59 & C sp3 & $\mathrm{HO} 3$ & -1920.79 & 6 & 6 \\
\hline 60 & C sp3 & HOF2 & -891.81 & 2 & 2 \\
\hline 61 & C sp3 & $\mathrm{BC} 3$ & 1320.43 & 3 & 1 \\
\hline 62 & Csp3 & $\mathrm{C} 4$ & -403.7 & 392 & 287 \\
\hline 63 & C sp3 & $\mathrm{C} 3 \mathrm{~N}$ & -886.44 & 46 & 34 \\
\hline 64 & C sp3 & $\mathrm{C} 3 \mathrm{~N}(+)$ & -875.68 & 28 & 26 \\
\hline 65 & C sp3 & $\mathrm{C} 3 \mathrm{O}$ & -876.38 & 181 & 135 \\
\hline 66 & Csp3 & $\mathrm{C} 3 \mathrm{~S}$ & -1050.27 & 23 & 19 \\
\hline 67 & C sp3 & $\mathrm{C} 3 \mathrm{~F}$ & -451.56 & 11 & 6 \\
\hline 68 & C sp3 & $\mathrm{C} 3 \mathrm{Cl}$ & -355.26 & 9 & 9 \\
\hline 69 & C sp3 & $\mathrm{C} 3 \mathrm{Br}$ & -362.07 & 2 & 2 \\
\hline 70 & C sp3 & C3J & -430.2 & 1 & 1 \\
\hline 71 & C sp3 & C2N2(+) & -1417.05 & 9 & 9 \\
\hline 72 & C sp3 & $\mathrm{C} 2 \mathrm{O} 2$ & -1331.4 & 42 & 38 \\
\hline 73 & C sp3 & $\mathrm{C} 2 \mathrm{~S} 2$ & -1708.54 & 4 & 1 \\
\hline 74 & C sp3 & $\mathrm{C} 2 \mathrm{~F} 2$ & -318.74 & 104 & 28 \\
\hline 75 & C sp3 & $\mathrm{C} 2 \mathrm{FCl}$ & -331.09 & 3 & 2 \\
\hline 76 & C sp3 & $\mathrm{C} 2 \mathrm{Cl} 2$ & -357.37 & 7 & 7 \\
\hline 77 & C sp3 & $\mathrm{CN} 3(+)$ & -2020.09 & 19 & 11 \\
\hline 78 & C sp3 & CN2F(+) & -1420.86 & 24 & 16 \\
\hline 79 & C sp3 & $\mathrm{CN} 2 \mathrm{Cl}(+)$ & -1451.19 & 2 & 2 \\
\hline 80 & C sp3 & CNF2 & -848.67 & 6 & 2 \\
\hline 81 & C sp3 & CNF2(+) & -853.81 & 3 & 2 \\
\hline 82 & C sp3 & $\mathrm{CO} 3$ & -1771.57 & 8 & 7 \\
\hline 83 & C sp3 & COF2 & -802.95 & 3 & 3 \\
\hline 84 & C sp3 & $\mathrm{COCl} 2$ & -893.67 & 1 & 1 \\
\hline 85 & C sp3 & CF3 & -251.65 & 83 & 64 \\
\hline 86 & C sp3 & $\mathrm{CF} 2 \mathrm{Cl}$ & -306.09 & 10 & 8 \\
\hline 87 & C sp3 & CF2Br & -319.62 & 5 & 4 \\
\hline 88 & Csp3 & $\mathrm{CFCl} 2$ & -317.2 & 7 & 7 \\
\hline 89 & C sp3 & $\mathrm{CFClBr}$ & -276.51 & 1 & 1 \\
\hline 90 & C sp3 & $\mathrm{CCl} 3$ & -371.89 & 25 & 24 \\
\hline 91 & C sp3 & $\mathrm{CBr} 3$ & -345.19 & 1 & 1 \\
\hline 92 & C sp3 & $\mathrm{N} 2 \mathrm{OF}(+)$ & -1875.95 & 1 & 1 \\
\hline 93 & C sp3 & $\mathrm{N} 4(+)$ & -2635.7 & 3 & 3 \\
\hline 94 & C sp3 & N3F(+) & -4981.42 & 2 & 2 \\
\hline 95 & C sp3 & $\mathrm{O} 4$ & -2239.99 & 3 & 3 \\
\hline 96 & C sp3 & $\mathrm{O} 2 \mathrm{~F} 2$ & -1255.75 & 1 & 1 \\
\hline
\end{tabular}


Table 4. Cont.

\begin{tabular}{|c|c|c|c|c|c|}
\hline Entry & Atom Type & Neighbors & Contribution & Occurrences & Molecules \\
\hline 97 & C sp3 & OF3 & -692.57 & 2 & 2 \\
\hline 98 & C sp3 & $\mathrm{OF} 2 \mathrm{Cl}$ & -768.91 & 1 & 1 \\
\hline 99 & $\mathrm{C}(-) \mathrm{sp} 3$ & $\mathrm{C} 3$ & -3078.32 & 2 & 2 \\
\hline 100 & C sp2 & $\mathrm{H} 2=\mathrm{C}$ & -703.3 & 255 & 227 \\
\hline 101 & C sp2 & $\mathrm{H} 2=\mathrm{N}$ & -1694.79 & 2 & 2 \\
\hline 102 & C sp2 & $\mathrm{HC}=\mathrm{C}$ & -563.48 & 1268 & 695 \\
\hline 103 & C sp2 & $\mathrm{HC}=\mathrm{N}$ & -1522.25 & 64 & 58 \\
\hline 104 & C sp2 & $\mathrm{HC}=\mathrm{O}$ & -390.29 & 115 & 111 \\
\hline 105 & C sp2 & $\mathrm{H}=\mathrm{CN}$ & -1024.99 & 141 & 103 \\
\hline 106 & C sp2 & $\mathrm{HC}=\mathrm{N}(+)$ & -5278.26 & 7 & 7 \\
\hline 107 & Csp2 & $\mathrm{H}=\mathrm{CN}(+)$ & -1032.17 & 4 & 4 \\
\hline 108 & C sp2 & $\mathrm{H}=\mathrm{CO}$ & -619.08 & 54 & 48 \\
\hline 109 & C sp2 & $\mathrm{H}=\mathrm{CS}$ & -1228.75 & 80 & 61 \\
\hline 110 & C sp2 & $\mathrm{H}=\mathrm{CF}$ & -547.73 & 2 & 2 \\
\hline 111 & C sp2 & $\mathrm{H}=\mathrm{CCl}$ & -550.31 & 8 & 6 \\
\hline 112 & C sp2 & $\mathrm{H}=\mathrm{CBr}$ & -574.22 & 2 & 2 \\
\hline 113 & C sp2 & $\mathrm{H}=\mathrm{CSi}$ & -1051.13 & 16 & 9 \\
\hline 114 & C sp2 & $\mathrm{HN}=\mathrm{N}$ & -1998.61 & 45 & 42 \\
\hline 115 & C sp2 & $\mathrm{HN}=\mathrm{O}$ & -830.28 & 12 & 11 \\
\hline 116 & C sp2 & $\mathrm{H}=\mathrm{NO}$ & -1583.32 & 2 & 2 \\
\hline 117 & C sp2 & $\mathrm{HO}=\mathrm{O}$ & -410.95 & 19 & 19 \\
\hline 118 & C sp2 & $\mathrm{H}=\mathrm{NS}$ & -2218.79 & 3 & 3 \\
\hline 119 & C sp2 & $C 2=C$ & -430.98 & 318 & 255 \\
\hline 120 & C sp2 & $\mathrm{C} 2=\mathrm{N}$ & -1378.53 & 82 & 67 \\
\hline 121 & C sp2 & $\mathrm{C} 2=\mathrm{N}(+)$ & 326.77 & 6 & 6 \\
\hline 122 & C sp2 & $\mathrm{C}=\mathrm{CN}$ & -893.41 & 86 & 66 \\
\hline 123 & C sp2 & $\mathrm{C}=\mathrm{CN}(+)$ & -928.07 & 10 & 10 \\
\hline 124 & C sp2 & $\mathrm{C} 2=\mathrm{O}$ & -241.97 & 400 & 337 \\
\hline 125 & C sp2 & $\mathrm{C}=\mathrm{CO}$ & -470.12 & 86 & 69 \\
\hline 126 & C sp2 & $\mathrm{C}=\mathrm{CS}$ & -1085.43 & 56 & 45 \\
\hline 127 & C sp2 & $\mathrm{C}=\mathrm{CF}$ & -452.88 & 7 & 6 \\
\hline 128 & C sp2 & $\mathrm{C}=\mathrm{CCl}$ & -418.16 & 22 & 13 \\
\hline 129 & C sp2 & $\mathrm{C}=\mathrm{CBr}$ & -412.66 & 1 & 1 \\
\hline 130 & C sp2 & $=\mathrm{CN} 2$ & -1367.07 & 11 & 11 \\
\hline 131 & C sp2 & $=\mathrm{CN} 2(+)$ & -1387.08 & 10 & 10 \\
\hline 132 & C sp2 & $\mathrm{CN}=\mathrm{N}$ & -1858.11 & 48 & 40 \\
\hline 133 & C sp2 & $\mathrm{CN}=\mathrm{N}(+)$ & -1939.3 & 6 & 6 \\
\hline 134 & C sp2 & $\mathrm{CN}=\mathrm{O}$ & -687.04 & 310 & 243 \\
\hline 135 & C sp2 & $\mathrm{C}=\mathrm{NO}$ & -1412.25 & 18 & 16 \\
\hline 136 & C sp2 & $=\mathrm{CNO}$ & -980.26 & 1 & 1 \\
\hline 137 & C sp2 & $=\mathrm{CNO}(+)$ & -1004.7 & 6 & 6 \\
\hline
\end{tabular}


Table 4. Cont.

\begin{tabular}{|c|c|c|c|c|c|}
\hline Entry & Atom Type & Neighbors & Contribution & Occurrences & Molecules \\
\hline 138 & C sp2 & $\mathrm{CN}=\mathrm{S}$ & -1516.78 & 7 & 6 \\
\hline 139 & C sp2 & $\mathrm{C}=\mathrm{NS}$ & -2037.97 & 6 & 6 \\
\hline 140 & C sp2 & $=\mathrm{CNS}(+)$ & -1601.01 & 2 & 2 \\
\hline 141 & C sp2 & $=\mathrm{CNCl}$ & -854.46 & 1 & 1 \\
\hline 142 & C sp2 & $\mathrm{CO}=\mathrm{O}$ & -256.51 & 1142 & 872 \\
\hline 143 & C sp2 & $\mathrm{CO}=\mathrm{O}(-)$ & 98.04 & 51 & 50 \\
\hline 144 & C sp2 & $\mathrm{C}=\mathrm{OS}$ & -913.81 & 7 & 7 \\
\hline 145 & C sp2 & $\mathrm{C}=\mathrm{OF}$ & -193.64 & 3 & 3 \\
\hline 146 & C sp2 & $\mathrm{C}=\mathrm{OCl}$ & -202.04 & 14 & 11 \\
\hline 147 & C sp2 & $\mathrm{C}=\mathrm{OBr}$ & -203.56 & 2 & 2 \\
\hline 148 & C sp2 & $\mathrm{C}=\mathrm{OJ}$ & -281.05 & 2 & 2 \\
\hline 149 & C sp2 & $=\mathrm{COF}$ & -297.83 & 2 & 2 \\
\hline 150 & C sp2 & $\mathrm{CS}=\mathrm{S}$ & -1716.14 & 3 & 3 \\
\hline 151 & C sp2 & $=\mathrm{CS} 2$ & -1853.93 & 2 & 1 \\
\hline 152 & C sp2 & $=\mathrm{CF} 2$ & -413.7 & 9 & 8 \\
\hline 153 & C sp2 & $=\mathrm{CFCl}$ & -362.02 & 1 & 1 \\
\hline 154 & C sp2 & $=\mathrm{CCl} 2$ & -420.11 & 7 & 5 \\
\hline 155 & C sp2 & $=\mathrm{CJ} 2$ & -544.25 & 2 & 1 \\
\hline 156 & C sp2 & $\mathrm{N} 2=\mathrm{N}$ & -2333.01 & 67 & 55 \\
\hline 157 & C sp2 & $\mathrm{N} 2=\mathrm{N}(+)$ & 583.11 & 2 & 2 \\
\hline 158 & C sp2 & $\mathrm{N} 2=\mathrm{O}$ & -1148.85 & 124 & 107 \\
\hline 159 & C sp2 & $\mathrm{N}=\mathrm{NO}$ & -1909.16 & 3 & 3 \\
\hline 160 & C sp2 & $\mathrm{N} 2=\mathrm{S}$ & -1999.02 & 27 & 25 \\
\hline 161 & C sp2 & $\mathrm{N}=\mathrm{NS}$ & -2485.54 & 10 & 9 \\
\hline 162 & C sp2 & $\mathrm{NO}=\mathrm{O}$ & -712.7 & 22 & 21 \\
\hline 163 & C sp2 & $\mathrm{N}=\mathrm{OS}$ & -1624.45 & 1 & 1 \\
\hline 164 & C sp2 & $\mathrm{NO}=\mathrm{S}$ & -1586.99 & 5 & 5 \\
\hline 165 & C sp2 & $=\mathrm{NOS}$ & -2019.32 & 1 & 1 \\
\hline 166 & C sp2 & $=\mathrm{NOCl}$ & -1416.86 & 1 & 1 \\
\hline 167 & C sp2 & $\mathrm{NS}=\mathrm{S}$ & -2180.9 & 6 & 6 \\
\hline 168 & C sp2 & $\mathrm{NS}=\mathrm{S}(-)$ & -2015.49 & 4 & 4 \\
\hline 169 & C sp2 & $=\mathrm{NSCl}$ & -2036.68 & 1 & 1 \\
\hline 170 & C sp2 & $\mathrm{O} 2=\mathrm{O}$ & -288.27 & 14 & 14 \\
\hline 171 & C sp2 & $\mathrm{O}=\mathrm{OCl}$ & -207.85 & 4 & 4 \\
\hline 172 & C sp2 & $=\mathrm{OS} 2$ & -1589.52 & 2 & 2 \\
\hline 173 & C sp2 & $\mathrm{S} 2=\mathrm{S}$ & -2384.68 & 3 & 3 \\
\hline 174 & $\mathrm{C}$ aromatic & $\mathrm{H}: \mathrm{C} 2$ & -544 & 10,741 & 1946 \\
\hline 175 & $\mathrm{C}$ aromatic & $\mathrm{H}: \mathrm{C}: \mathrm{N}$ & -677.57 & 176 & 121 \\
\hline 176 & C aromatic & $\mathrm{H}: \mathrm{C}: \mathrm{N}(+)$ & -664.15 & 46 & 25 \\
\hline 177 & C aromatic & H:N2 & -805.13 & 12 & 10 \\
\hline 178 & $\mathrm{C}$ aromatic & :C3 & -404.91 & 496 & 193 \\
\hline
\end{tabular}


Table 4. Cont.

\begin{tabular}{|c|c|c|c|c|c|}
\hline Entry & Atom Type & Neighbors & Contribution & Occurrences & Molecules \\
\hline 179 & $\mathrm{C}$ aromatic & $\mathrm{C}: \mathrm{C} 2$ & -412.39 & 2572 & 1349 \\
\hline 180 & $\mathrm{C}$ aromatic & $\mathrm{C}: \mathrm{C}: \mathrm{N}$ & -537.55 & 106 & 62 \\
\hline 181 & C aromatic & $\mathrm{C}: \mathrm{C}: \mathrm{N}(+)$ & -537.4 & 37 & 21 \\
\hline 182 & C aromatic & $: \mathrm{C} 2 \mathrm{~N}$ & -904.12 & 521 & 380 \\
\hline 183 & $\mathrm{C}$ aromatic & :C2N(+) & -924.19 & 323 & 214 \\
\hline 184 & $\mathrm{C}$ aromatic & $: \mathrm{C} 2: \mathrm{N}$ & -541.18 & 73 & 54 \\
\hline 185 & C aromatic & :C2:N(+) & -537.03 & 33 & 18 \\
\hline 186 & $\mathrm{C}$ aromatic & $\mathrm{C} 2 \mathrm{O}$ & -485.35 & 724 & 496 \\
\hline 187 & $\mathrm{C}$ aromatic & $: \mathrm{C} 2 \mathrm{P}$ & -739.79 & 9 & 3 \\
\hline 188 & C aromatic & :C2S & -1093.91 & 94 & 75 \\
\hline 189 & C aromatic & :C2Si & -977.52 & 30 & 11 \\
\hline 190 & $\mathrm{C}$ aromatic & $: \mathrm{C} 2 \mathrm{~F}$ & -400.21 & 136 & 67 \\
\hline 191 & $\mathrm{C}$ aromatic & $: \mathrm{C} 2 \mathrm{Cl}$ & -391.36 & 235 & 137 \\
\hline 192 & C aromatic & $: \mathrm{C} 2 \mathrm{Br}$ & -393.11 & 72 & 50 \\
\hline 193 & C aromatic & :C2J & -466.27 & 39 & 34 \\
\hline 194 & $\mathrm{C}$ aromatic & $\mathrm{C}: \mathrm{N} 2$ & -653.04 & 5 & 3 \\
\hline 195 & C aromatic & :CN:N & -1014.82 & 17 & 13 \\
\hline 196 & $\mathrm{C}$ aromatic & $: \mathrm{CN}: \mathrm{N}(+)$ & -1105.83 & 3 & 2 \\
\hline 197 & $\mathrm{C}$ aromatic & :C:NO & -567.84 & 11 & 11 \\
\hline 198 & C aromatic & :C:NCl & -521.23 & 30 & 21 \\
\hline 199 & C aromatic & $: \mathrm{C}: \mathrm{NBr}$ & -517.98 & 4 & 3 \\
\hline 200 & C aromatic & $\mathrm{N}: \mathrm{N} 2$ & -1126.33 & 22 & 14 \\
\hline 201 & $\mathrm{C}$ aromatic & :N2O & -708.43 & 17 & 6 \\
\hline 202 & $\mathrm{C}$ aromatic & :N2S & -1372.64 & 1 & 1 \\
\hline 203 & $\mathrm{C}$ aromatic & :N2Cl & -639.79 & 11 & 10 \\
\hline 204 & $\mathrm{C}(+)$ aromatic & $\mathrm{H}: \mathrm{N} 2$ & 915.78 & 17 & 17 \\
\hline 205 & $\mathrm{C}(+)$ aromatic & :N3 & 1847.84 & 3 & 3 \\
\hline 206 & C sp & $\mathrm{H \# C}$ & -654.9 & 50 & 42 \\
\hline 207 & C sp & $\mathrm{C \# C}$ & -502.89 & 198 & 108 \\
\hline 208 & C sp & $=\mathrm{C} 2$ & -532.17 & 12 & 11 \\
\hline 209 & C sp & $\mathrm{C \# N}$ & -495.27 & 165 & 139 \\
\hline 210 & C sp & $\mathrm{C \# N}(+)$ & -521.62 & 4 & 3 \\
\hline 211 & C sp & C\#N(-) & 378.06 & 6 & 2 \\
\hline 212 & C sp & $\# \mathrm{CN}$ & -1069.64 & 2 & 2 \\
\hline 213 & C sp & $=\mathrm{C}=\mathrm{N}$ & -1519.98 & 2 & 2 \\
\hline 214 & $\mathrm{Csp}$ & $=\mathrm{C}=\mathrm{O}$ & -281.24 & 4 & 3 \\
\hline 215 & C sp & \#CS & -1214.94 & 2 & 2 \\
\hline 216 & C sp & $\# \mathrm{CCl}$ & -514.93 & 3 & 2 \\
\hline 217 & C sp & \#CSi & -1091.51 & 3 & 3 \\
\hline 218 & C sp & $\mathrm{N \# N}$ & -982.36 & 4 & 4 \\
\hline 219 & C sp & $\mathrm{N \# N(-)}$ & -144.09 & 10 & 5 \\
\hline
\end{tabular}


Table 4. Cont.

\begin{tabular}{|c|c|c|c|c|c|}
\hline Entry & Atom Type & Neighbors & Contribution & Occurrences & Molecules \\
\hline 220 & C sp & $=\mathrm{N} 2$ & -2404.6 & 2 & 2 \\
\hline 221 & C sp & \#NO & -648.9 & 2 & 2 \\
\hline 222 & C sp & $=\mathrm{N}=\mathrm{O}$ & -1216.26 & 22 & 16 \\
\hline 223 & C sp & \#NS & -1277.41 & 1 & 1 \\
\hline 224 & C sp & $=\mathrm{N}=\mathrm{S}$ & -2056.03 & 2 & 2 \\
\hline 225 & C sp & $=\mathrm{N}=\mathrm{S}(-)$ & -1076.3 & 2 & 2 \\
\hline 226 & N sp3 & $\mathrm{H} 2 \mathrm{C}$ & 218.81 & 64 & 56 \\
\hline 227 & N sp3 & $\mathrm{H} 2 \mathrm{C}(\mathrm{pi})$ & 253.54 & 334 & 285 \\
\hline 228 & $\mathrm{~N} \mathrm{sp3}$ & $\mathrm{H} 2 \mathrm{~N}$ & -304.07 & 29 & 23 \\
\hline 229 & N sp3 & $\mathrm{H} 2 \mathrm{~N}(\mathrm{pi})$ & -266.71 & 1 & 1 \\
\hline 230 & N sp3 & $\mathrm{H} 2 \mathrm{~S}$ & 215.36 & 9 & 9 \\
\hline 231 & N sp3 & HC2 & 814.55 & 69 & 63 \\
\hline 232 & $\mathrm{~N}$ sp3 & HC2(pi) & 846.53 & 138 & 105 \\
\hline 233 & N sp3 & HC2(2pi) & 845.11 & 253 & 200 \\
\hline 234 & N sp3 & $\mathrm{HCN}$ & 288.21 & 5 & 3 \\
\hline 235 & N sp3 & $\mathrm{HCN}(\mathrm{pi})$ & 315.32 & 41 & 28 \\
\hline 236 & N sp3 & $\mathrm{HCN}(+)(\mathrm{pi})$ & 734.53 & 5 & 4 \\
\hline 237 & N sp3 & $\mathrm{HCN}(2 \mathrm{pi})$ & 359.34 & 69 & 64 \\
\hline 238 & $\mathrm{~N} \mathrm{sp3}$ & $\mathrm{HCN}(+)(2 \mathrm{pi})$ & 717.66 & 6 & 6 \\
\hline 239 & $\mathrm{~N} \mathrm{sp3}$ & $\mathrm{HCO}(\mathrm{pi})$ & 520.5 & 2 & 2 \\
\hline 240 & N sp3 & HCS(pi) & 1015.17 & 3 & 3 \\
\hline 241 & $\mathrm{~N} \mathrm{sp3}$ & HCSi & 829.19 & 5 & 5 \\
\hline 242 & N sp3 & HN2(2pi) & -176.66 & 1 & 1 \\
\hline 243 & $\mathrm{~N} \mathrm{sp3}$ & HNS & 552.34 & 1 & 1 \\
\hline 244 & N sp3 & HSi2 & 850.75 & 1 & 1 \\
\hline 245 & $\mathrm{~N} \mathrm{sp3}$ & $\mathrm{C} 3$ & 1409.08 & 84 & 73 \\
\hline 246 & N sp3 & C3(pi) & 1429.38 & 98 & 84 \\
\hline 247 & $\mathrm{~N}$ sp3 & C3(2pi) & 1430.98 & 69 & 52 \\
\hline 248 & $\mathrm{~N} \mathrm{sp3}$ & C3(3pi) & 1421.7 & 31 & 23 \\
\hline 249 & N sp3 & $\mathrm{C} 2 \mathrm{~N}$ & 871.27 & 1 & 1 \\
\hline 250 & N sp3 & $\mathrm{C} 2 \mathrm{~N}(\mathrm{pi})$ & 896.78 & 13 & 11 \\
\hline 251 & N sp3 & $\mathrm{C} 2 \mathrm{~N}(+)(\mathrm{pi})$ & 1320.4 & 40 & 25 \\
\hline 252 & N sp3 & C2N(2pi) & 954 & 23 & 22 \\
\hline 253 & $\mathrm{~N}$ sp3 & $\mathrm{C} 2 \mathrm{~N}(+)(2 \mathrm{pi})$ & 1269.38 & 12 & 7 \\
\hline 254 & N sp3 & C2N(3pi) & 948.11 & 9 & 9 \\
\hline 255 & $\mathrm{~N} \mathrm{sp3}$ & $\mathrm{C} 2 \mathrm{~N}(+)(3 \mathrm{pi})$ & 1230.43 & 3 & 3 \\
\hline 256 & $\mathrm{~N} \mathrm{sp3}$ & $\mathrm{C} 2 \mathrm{O}$ & 1037.7 & 3 & 3 \\
\hline 257 & N sp3 & $\mathrm{C} 2 \mathrm{~S}$ & 584.44 & 6 & 3 \\
\hline 258 & N sp3 & $\mathrm{C} 2 \mathrm{Si}$ & 1437.12 & 8 & 6 \\
\hline 259 & N sp3 & $\mathrm{C} 2 \mathrm{~F}(2 \mathrm{pi})$ & -2337.09 & 1 & 1 \\
\hline 260 & $\mathrm{~N} \mathrm{sp3}$ & $\mathrm{C} 2 \mathrm{Cl}(2 \mathrm{pi})$ & 878.7 & 1 & 1 \\
\hline
\end{tabular}


Table 4. Cont.

\begin{tabular}{|c|c|c|c|c|c|}
\hline Entry & Atom Type & Neighbors & Contribution & Occurrences & Molecules \\
\hline 261 & $\mathrm{~N} \mathrm{sp3}$ & $\mathrm{C} 2 \mathrm{Br}(2 \mathrm{pi})$ & 900.67 & 1 & 1 \\
\hline 262 & N sp3 & CN2(2pi) & 491.47 & 9 & 7 \\
\hline 263 & $\mathrm{~N} \mathrm{sp3}$ & $\mathrm{CN} 2(+)(2 \mathrm{pi})$ & 1183.51 & 1 & 1 \\
\hline 264 & $\mathrm{~N} \mathrm{sp3}$ & CN2(3pi) & 550.35 & 3 & 3 \\
\hline 265 & N sp3 & CN2(+)(3pi) & 774.31 & 3 & 3 \\
\hline 266 & N sp3 & CF2 & 197.51 & 12 & 7 \\
\hline 267 & N sp3 & CF2(pi) & 997.31 & 1 & 1 \\
\hline 268 & N sp3 & $\mathrm{Si} 3$ & 1479.07 & 1 & 1 \\
\hline 269 & $\mathrm{~N} \mathrm{sp2}$ & $\mathrm{H}=\mathrm{C}$ & 760 & 10 & 10 \\
\hline 270 & N sp2 & $\mathrm{C}=\mathrm{C}$ & 1411.35 & 154 & 133 \\
\hline 271 & $\mathrm{~N} \mathrm{sp} 2$ & $\mathrm{C}=\mathrm{N}$ & 375.86 & 70 & 38 \\
\hline 272 & $\mathrm{~N} \mathrm{sp2}$ & $\mathrm{C}=\mathrm{N}(+)$ & 714.59 & 35 & 31 \\
\hline 273 & $\mathrm{~N} \mathrm{sp} 2$ & $=\mathrm{CN}$ & 866.59 & 141 & 117 \\
\hline 274 & $\mathrm{~N} \mathrm{sp} 2$ & $=\mathrm{CN}(+)$ & 1299.9 & 5 & 5 \\
\hline 275 & $\mathrm{~N} \mathrm{sp} 2$ & $\mathrm{C}=\mathrm{O}$ & 421.69 & 13 & 12 \\
\hline 276 & $\mathrm{~N} \mathrm{sp} 2$ & $=\mathrm{CO}$ & 935.48 & 78 & 55 \\
\hline 277 & $\mathrm{~N} \mathrm{sp2}$ & $=\mathrm{CS}$ & 705.75 & 2 & 1 \\
\hline 278 & $\mathrm{~N} \mathrm{sp} 2$ & $=\mathrm{CF}$ & 0 & 1 & 1 \\
\hline 279 & $\mathrm{~N} \mathrm{sp} 2$ & $\mathrm{~N}=\mathrm{N}$ & -82.18 & 80 & 41 \\
\hline 280 & $\mathrm{~N} \mathrm{sp} 2$ & $\mathrm{~N}=\mathrm{O}$ & 1.35 & 8 & 6 \\
\hline 281 & $\mathrm{~N} \mathrm{sp} 2$ & $=\mathrm{NO}$ & 762.47 & 2 & 1 \\
\hline 282 & $\mathrm{~N} \mathrm{sp} 2$ & $=\mathrm{NO}(+)$ & 1041.44 & 11 & 6 \\
\hline 283 & $\mathrm{~N} \mathrm{sp} 2$ & $\mathrm{O}=\mathrm{O}$ & 831.52 & 9 & 9 \\
\hline 284 & $\mathrm{~N} \mathrm{sp} 2$ & $\mathrm{P}=\mathrm{P}$ & -482.14 & 7 & 2 \\
\hline 285 & $\mathrm{~N}$ aromatic & $\mathrm{H} 2: \mathrm{C}(+)$ & -1025.73 & 5 & 3 \\
\hline 286 & $\mathrm{~N}$ aromatic & $\mathrm{HC}: \mathrm{C}(+)$ & -363.24 & 2 & 2 \\
\hline 287 & $\mathrm{~N}$ aromatic & $\mathrm{C} 2: \mathrm{C}(+)$ & 216.63 & 36 & 19 \\
\hline 288 & $\mathrm{~N}$ aromatic & :C2 & 214.34 & 273 & 189 \\
\hline 289 & $\mathrm{~N}$ aromatic & :C:N & 41.42 & 6 & 3 \\
\hline 290 & $\mathrm{~N}$ aromatic & $: \mathrm{C}: \mathrm{N}(+)$ & 2190.8 & 1 & 1 \\
\hline 291 & $\mathrm{~N}(+) \mathrm{sp} 3$ & Н3С & 57.66 & 47 & 46 \\
\hline 292 & $\mathrm{~N}(+) \mathrm{sp} 3$ & $\mathrm{H} 2 \mathrm{C} 2$ & 607.96 & 9 & 9 \\
\hline 293 & $\mathrm{~N}(+) \mathrm{sp} 3$ & $\mathrm{HC} 3$ & 1364.55 & 6 & 4 \\
\hline 294 & $\mathrm{~N}(+) \mathrm{sp} 3$ & $\mathrm{C} 4$ & 1885.72 & 8 & 8 \\
\hline 295 & $\mathrm{~N}(+) \mathrm{sp} 2$ & $\mathrm{C}=\mathrm{CO}(-)$ & 5214.75 & 7 & 7 \\
\hline 296 & $\mathrm{~N}(+) \mathrm{sp} 2$ & $\mathrm{C}=\mathrm{NO}$ & 442.92 & 16 & 8 \\
\hline 297 & $\mathrm{~N}(+) \mathrm{sp} 2$ & $\mathrm{C}=\mathrm{NO}(-)$ & 155.64 & 16 & 11 \\
\hline 298 & $\mathrm{~N}(+) \mathrm{sp} 2$ & $\mathrm{CO}=\mathrm{O}(-)$ & 548.28 & 550 & 310 \\
\hline 299 & $\mathrm{~N}(+) \mathrm{sp} 2$ & $=\mathrm{CO} 2(-)$ & -568.22 & 6 & 6 \\
\hline 300 & $\mathrm{~N}(+) \mathrm{sp} 2$ & $\mathrm{NO}=\mathrm{O}(-)$ & -366.72 & 76 & 54 \\
\hline 301 & $\mathrm{~N}(+) \mathrm{sp} 2$ & $\mathrm{O} 2=\mathrm{O}(-)$ & 188.79 & 73 & 37 \\
\hline
\end{tabular}


Table 4. Cont.

\begin{tabular}{|c|c|c|c|c|c|}
\hline Entry & Atom Type & Neighbors & Contribution & Occurrences & Molecules \\
\hline 302 & $\mathrm{~N}(+)$ aromatic & $\mathrm{C}: \mathrm{C} 2$ & 698.75 & 1 & 1 \\
\hline 303 & $\mathrm{~N}(+)$ aromatic & :C2O(-) & 234.67 & 58 & 40 \\
\hline 304 & $\mathrm{~N}(+)$ aromatic & :C:NO(-) & -2193.1 & 1 & 1 \\
\hline 305 & $\mathrm{~N}(+) \mathrm{sp}$ & C\#C(-) & -94.07 & 6 & 6 \\
\hline 306 & $\mathrm{~N}(+) \mathrm{sp}$ & $\# \mathrm{CO}(-)$ & 0 & 4 & 3 \\
\hline 307 & $\mathrm{~N}(+) \mathrm{sp}$ & $=\mathrm{N} 2(-)$ & -542.94 & 30 & 26 \\
\hline 308 & $\mathrm{~N}(-)$ & $\mathrm{C} 2$ & -776.85 & 5 & 5 \\
\hline 309 & $\mathrm{O}$ & $\mathrm{HC}$ & 550.37 & 663 & 373 \\
\hline 310 & $\mathrm{O}$ & $\mathrm{HC}(\mathrm{pi})$ & 149.9 & 795 & 622 \\
\hline 311 & $\mathrm{O}$ & $\mathrm{HN}$ & -183.46 & 3 & 3 \\
\hline 312 & $\mathrm{O}$ & $\mathrm{HN}(\mathrm{pi})$ & -66.29 & 29 & 23 \\
\hline 313 & $\mathrm{O}$ & $\mathrm{HO}$ & -35.98 & 29 & 26 \\
\hline 314 & $\mathrm{O}$ & $\mathrm{HP}$ & -107.27 & 3 & 2 \\
\hline 315 & $\mathrm{O}$ & HS & 346.8 & 8 & 8 \\
\hline 316 & $\mathrm{O}$ & $\mathrm{HSi}$ & 241.58 & 1 & 1 \\
\hline 317 & $\mathrm{O}$ & $\mathrm{BC}$ & 1904.24 & 2 & 2 \\
\hline 318 & $\mathrm{O}$ & $\mathrm{C} 2$ & 1101.66 & 471 & 283 \\
\hline 319 & $\mathrm{O}$ & C2(pi) & 701.99 & 896 & 686 \\
\hline 320 & $\mathrm{O}$ & C2(2pi) & 278.25 & 167 & 156 \\
\hline 321 & $\mathrm{O}$ & $\mathrm{CN}(\mathrm{pi})$ & -291.5 & 24 & 18 \\
\hline 322 & $\mathrm{O}$ & $\mathrm{CN}(+)(\mathrm{pi})$ & 401.59 & 63 & 29 \\
\hline 323 & $\mathrm{O}$ & $\mathrm{CN}(2 \mathrm{pi})$ & 131.93 & 14 & 14 \\
\hline 324 & $\mathrm{O}$ & $\mathrm{CN}(+)(2 \mathrm{pi})$ & 398.5 & 1 & 1 \\
\hline 325 & $\mathrm{O}$ & $\mathrm{CO}$ & 523.43 & 120 & 65 \\
\hline 326 & $\mathrm{O}$ & $\mathrm{CO}(\mathrm{pi})$ & 113.28 & 65 & 29 \\
\hline 327 & $\mathrm{O}$ & $\mathrm{CS}$ & 457.66 & 18 & 9 \\
\hline 328 & $\mathrm{O}$ & $\mathrm{CP}$ & 542.76 & 10 & 4 \\
\hline 329 & $\mathrm{O}$ & $\mathrm{CP}(\mathrm{pi})$ & 91.26 & 3 & 1 \\
\hline 330 & $\mathrm{O}$ & $\mathrm{CSi}$ & 708.96 & 54 & 21 \\
\hline 331 & $\mathrm{O}$ & CSi(pi) & 318.69 & 38 & 15 \\
\hline 332 & $\mathrm{O}$ & N2(2pi) & -65.35 & 15 & 14 \\
\hline 333 & $\mathrm{O}$ & $\mathrm{N} 2(+)(2 \mathrm{pi})$ & -220.1 & 5 & 5 \\
\hline 334 & $\mathrm{O}$ & OSi & 106.92 & 8 & 4 \\
\hline 335 & $\mathrm{O}$ & $\mathrm{Si} 2$ & 400.13 & 11 & 3 \\
\hline 336 & P3 & $\mathrm{C} 3$ & 124.54 & 3 & 3 \\
\hline 337 & $\mathrm{P} 4$ & $\mathrm{C} 3=\mathrm{O}$ & -243.18 & 1 & 1 \\
\hline 338 & $\mathrm{P} 4$ & $\mathrm{C} 3=\mathrm{S}$ & -373.61 & 1 & 1 \\
\hline 339 & $\mathrm{P} 4$ & $\mathrm{C} 2 \mathrm{O}=\mathrm{O}$ & -169.24 & 1 & 1 \\
\hline 340 & $\mathrm{P} 4$ & $\mathrm{CO} 2=\mathrm{O}$ & 197.04 & 1 & 1 \\
\hline 341 & $\mathrm{P} 4$ & $\mathrm{CO} 2=\mathrm{O}(-)$ & -394.07 & 1 & 1 \\
\hline 342 & $\mathrm{P} 4$ & $\mathrm{~N}=\mathrm{NCl} 2$ & 0 & 7 & 2 \\
\hline
\end{tabular}


Table 4. Cont.

\begin{tabular}{|c|c|c|c|c|c|}
\hline Entry & Atom Type & Neighbors & Contribution & Occurrences & Molecules \\
\hline 343 & $\mathrm{P} 4$ & $\mathrm{O} 3=\mathrm{O}$ & 14.1 & 4 & 4 \\
\hline 344 & S2 & $\mathrm{HC}$ & -88.46 & 47 & 42 \\
\hline 345 & S2 & HC(pi) & -58.54 & 10 & 10 \\
\hline 346 & S2 & $\mathrm{C} 2$ & 690.55 & 78 & 66 \\
\hline 347 & S2 & C2(pi) & 714.51 & 26 & 21 \\
\hline 348 & S2 & C2(2pi) & 750.83 & 88 & 82 \\
\hline 349 & S2 & $\mathrm{CN}(\mathrm{pi})$ & -618.03 & 1 & 1 \\
\hline 350 & S2 & CS & 42.29 & 18 & 9 \\
\hline 351 & S2 & CS(pi) & 53.77 & 16 & 8 \\
\hline 352 & S2 & N2 & 25.26 & 1 & 1 \\
\hline 353 & S2 & N2(2pi) & 0 & 1 & 1 \\
\hline 354 & S2 & NS & -291.87 & 2 & 1 \\
\hline 355 & S4 & $\mathrm{C} 2=\mathrm{O}$ & 849.53 & 8 & 8 \\
\hline 356 & S4 & $\mathrm{C} 2=\mathrm{O} 2$ & 1073.53 & 43 & 43 \\
\hline 357 & S4 & $\mathrm{CN}=\mathrm{O} 2$ & -41.35 & 11 & 11 \\
\hline 358 & S4 & $\mathrm{CO}=\mathrm{O} 2$ & 216.14 & 3 & 3 \\
\hline 359 & S4 & $\mathrm{CO}=\mathrm{O} 2(-)$ & 777.27 & 2 & 2 \\
\hline 360 & S4 & $\mathrm{C}=\mathrm{O} 2 \mathrm{~S}$ & 394.52 & 2 & 1 \\
\hline 361 & S4 & $\mathrm{N} 2=\mathrm{O} 2$ & 558.49 & 1 & 1 \\
\hline 362 & S4 & $\mathrm{NO}=\mathrm{O} 2$ & -918.69 & 1 & 1 \\
\hline 363 & S4 & $\mathrm{O} 2=\mathrm{O}$ & -92.99 & 5 & 5 \\
\hline 364 & $\mathrm{~S} 4$ & $\mathrm{O} 2=\mathrm{O} 2$ & 116.23 & 4 & 4 \\
\hline 365 & S4 & $\mathrm{O} 2=\mathrm{O} 2(-)$ & -556.38 & 4 & 4 \\
\hline 366 & S4 & $\mathrm{O}=\mathrm{O} 2 \mathrm{~F}$ & -470.05 & 1 & 1 \\
\hline 367 & S4 & $\mathrm{O}=\mathrm{O} 2 \mathrm{Cl}$ & -463.63 & 1 & 1 \\
\hline 368 & $\mathrm{Si}$ & $\mathrm{H} 3 \mathrm{C}$ & -740.19 & 4 & 4 \\
\hline 369 & $\mathrm{Si}$ & $\mathrm{H} 2 \mathrm{C} 2$ & 12.42 & 2 & 2 \\
\hline 370 & $\mathrm{Si}$ & $\mathrm{HC} 3$ & 602.13 & 29 & 29 \\
\hline 371 & $\mathrm{Si}$ & $\mathrm{HC} 2 \mathrm{Cl}$ & 67.18 & 1 & 1 \\
\hline 372 & $\mathrm{Si}$ & $\mathrm{HCCl} 2$ & -100.05 & 1 & 1 \\
\hline 373 & $\mathrm{Si}$ & HN3 & -2430.7 & 1 & 1 \\
\hline 374 & $\mathrm{Si}$ & $\mathrm{HO} 3$ & -931.42 & 1 & 1 \\
\hline 375 & $\mathrm{Si}$ & $\mathrm{C} 4$ & 1327.16 & 15 & 15 \\
\hline 376 & $\mathrm{Si}$ & $\mathrm{C} 3 \mathrm{~N}$ & 317.05 & 15 & 12 \\
\hline 377 & $\mathrm{Si}$ & $\mathrm{C} 3 \mathrm{O}$ & 813.97 & 12 & 12 \\
\hline 378 & $\mathrm{Si}$ & $\mathrm{C} 3 \mathrm{Cl}$ & 1013.39 & 1 & 1 \\
\hline 379 & $\mathrm{Si}$ & $\mathrm{C} 3 \mathrm{Br}$ & 1000.85 & 1 & 1 \\
\hline 380 & $\mathrm{Si}$ & $\mathrm{C} 2 \mathrm{O} 2$ & 285.19 & 16 & 8 \\
\hline 381 & $\mathrm{Si}$ & $\mathrm{C} 2 \mathrm{Cl} 2$ & 592.69 & 3 & 3 \\
\hline 382 & $\mathrm{Si}$ & $\mathrm{CO} 3$ & -235.18 & 16 & 16 \\
\hline 383 & $\mathrm{Si}$ & $\mathrm{CCl} 3$ & 145.43 & 1 & 1 \\
\hline
\end{tabular}


Table 4. Cont.

\begin{tabular}{|c|c|c|c|c|c|}
\hline Entry & Atom Type & Neighbors & Contribution & Occurrences & Molecules \\
\hline 384 & $\mathrm{Si}$ & O4 & -763.98 & 7 & 7 \\
\hline 385 & $\mathrm{H}$ & H Acceptor & 0.27 & 241 & 188 \\
\hline 386 & $\mathrm{H}$ &. $\mathrm{H}$ & -5.79 & 381 & 142 \\
\hline 387 & $\mathrm{H}$ &.. $\mathrm{H}$ & -1.31 & 4908 & 1297 \\
\hline 388 & Angle60 & & -35.25 & 405 & 118 \\
\hline 389 & Angle90 & & -24.51 & 321 & 66 \\
\hline 390 & Angle102 & & -4.65 & 1663 & 451 \\
\hline A & Based on & Valid groups & 267 & & 5030 \\
\hline B & Goodness of fit & $\mathrm{R}^{2}$ & 1 & & 4886 \\
\hline $\mathrm{C}$ & Deviation & Average & 13.66 & & 4886 \\
\hline $\mathrm{D}$ & Deviation & Standard & 18.12 & & 4886 \\
\hline $\mathrm{E}$ & K-fold cv & $\mathrm{K}$ & 10 & & 4790 \\
\hline $\mathrm{F}$ & Goodness of fit & $\mathrm{Q}^{2}$ & 1 & & 4790 \\
\hline G & Deviation & Average (cv) & 14.44 & & 4790 \\
\hline $\mathrm{H}$ & Deviation & Standard (cv) & 19.16 & & 4790 \\
\hline
\end{tabular}

\section{Sources of Heat-of-Combustion and Formation Data}

The present list of references encompasses the sources for the experimental standard heats of combustion as well as those of formation, because the input of the heat of combustion into a molecule's database immediately also triggers the calculation and addition of its heat of formation and vice versa. Experimental data given in $\mathrm{kcal} / \mathrm{mol}$ are translated into $\mathrm{kJ} / \mathrm{mol}$ by multiplication with 4.1858 .

A large number of experimental data have been provided by several comprehensive papers; in particular, Domalski's collection [21] published an extended variation of compounds containing the elements C, H, N, O, P, and S. The CRC Handbook of Chemistry and Physics [22] included a chapter containing the heats of formation of another large list of compounds. In the last 6 years since the publication of the predecessor version [1] of this paper, a large number of publications have been found, which produced further experimental combustion and formation data. In the following, they have been sorted by their dominant contributory structural features to the present subject. An especially extended amount of research has been done with hydrocarbons including alkanes, alkenes, alkynes, and aromatics [23-60], forming the core of the various carbon groups. In addition, many data have dealt specifically with alcohols and phenol derivatives [61-74], ethers [75-84], carbaldehydes [85-94], ketones [95-112], carboxylic acids [113-135], carboxylic esters, carbonates and lactones [136-154], sugars [155], peroxides [156-161], amines and imines [162-169], amides, imides, amidines and hydrazides [170-186], guanidines [187,188], ureas [189-196], urethanes [197], carbamates [198], azides [199,200], nitriles and nitriloxides [201-208], isocyanates [209], oximes [210], nitramines [211], azo- and azoxy compounds [212-214], $N$-oxides [215-230], nitroso [231] and nitro compounds [232-263], nitrates [264], amino acids [265-277], sulfur-containing [278-289], phosphorus-containing [290], silicon-containing [291-294], and boron-containing compounds [295]. Beyond these, a large number of halogen-substituted compounds, many of them carrying any of the further functional groups just mentioned, have been found [296-357]. A considerable number of experimental combustion and formation data have been published for heterocyclic compounds, including hetarenes, unsubstituted and substituted by functional groups just mentioned. According to the hetero elements in the ring system, they have been subdivided into $N_{x}$-heterocycles (where $x$ is 1 to 4) [358-423], $\mathrm{N}, \mathrm{O}-$ heterocycles [424-433], N,S-heterocycles [434-438], $\mathrm{O}_{\mathrm{x}}$-heterocycles [439-452], and 
Sx-heterocycles [280,282-284,453-461]. A small number of papers contributed data for hetarenes with several element combinations [462-471]. In addition, and as an important extension to the earlier paper [1], a great variety of ionic liquids has been added [472-498]. Finally, a number of publications contributed combustion and/or formation data that could not be assigned to any of the aforementioned classes [499-526].

\section{Results}

\subsection{Heat of Combustion}

The first preliminary calculations of the group contributions were based on the complete set of 5560 compounds for which experimental heats of combustion and/or formation were available. However, contrary to the approach in the earlier paper [1], a further restriction was introduced in that only those compounds were allowed to remain in the consecutive calculations, the experimental values of which did not deviate by more than three times the cross-validated standard error from the cross-validated calculated value. Accordingly, the final group contributions rested on 5030 compounds, as shown on row A in Table 4 . The discarded molecules have been collected in an outliers list, available with Supplementary Materials. As a consequence, the correlation coefficient $\mathrm{Q}^{2}$ is even better than the previously published value of 0.9999 and is now indistinguishable from 1 (row $F$ in Table 4). Analogously, the new cross-validated standard error of $19.16 \mathrm{~kJ} / \mathrm{mol}$ (row H in Table 4) is considerably better than the earlier one of $25.2 \mathrm{~kJ} / \mathrm{mol}$. Not surprisingly, the mean absolute deviation over 4886 compounds is just $0.4 \%$ over a calculated heat-ofcombustion range of from $-72 \mathrm{~kJ} / \mathrm{mol}$ (hydrogen peroxide) to $-35,112.2 \mathrm{~kJ} / \mathrm{mol}$ (glycerol trioleate). These excellent statistical data are well reflected in the straight line of the data points in the correlation diagram of Figure 1 and the perfectly symmmetrically balanced Gaussian bell curve of the histogram in Figure 2. The only downside, however, is the much longer list of 390 atoms and special groups required (compared to the 273 of the earlier paper [1]), of which only 267 are "valid" for predictions. However, the latter still enable the calculation of the heats of combustion and formation of presently 29,067 molecules, i.e., ca. $84.5 \%$ of the complete dataset. The complete set of molecules used for the group-parameters calculations is available in the Supplementary Material.

The extraordinary accuracy of the predictions allows a deeper analysis of the actual structural state of certain classes of molecules for which alternative structures are possible at standard conditions, in particular as to which prototropic forms are prevailing in amino acids and which tautomeric form is prevalent in compounds that may exist in both hydroxyazo and hydrazone or keto and enol forms. Beyond this, an educated estimate as to what the enthalpy difference is between the alternative forms might be possible. 


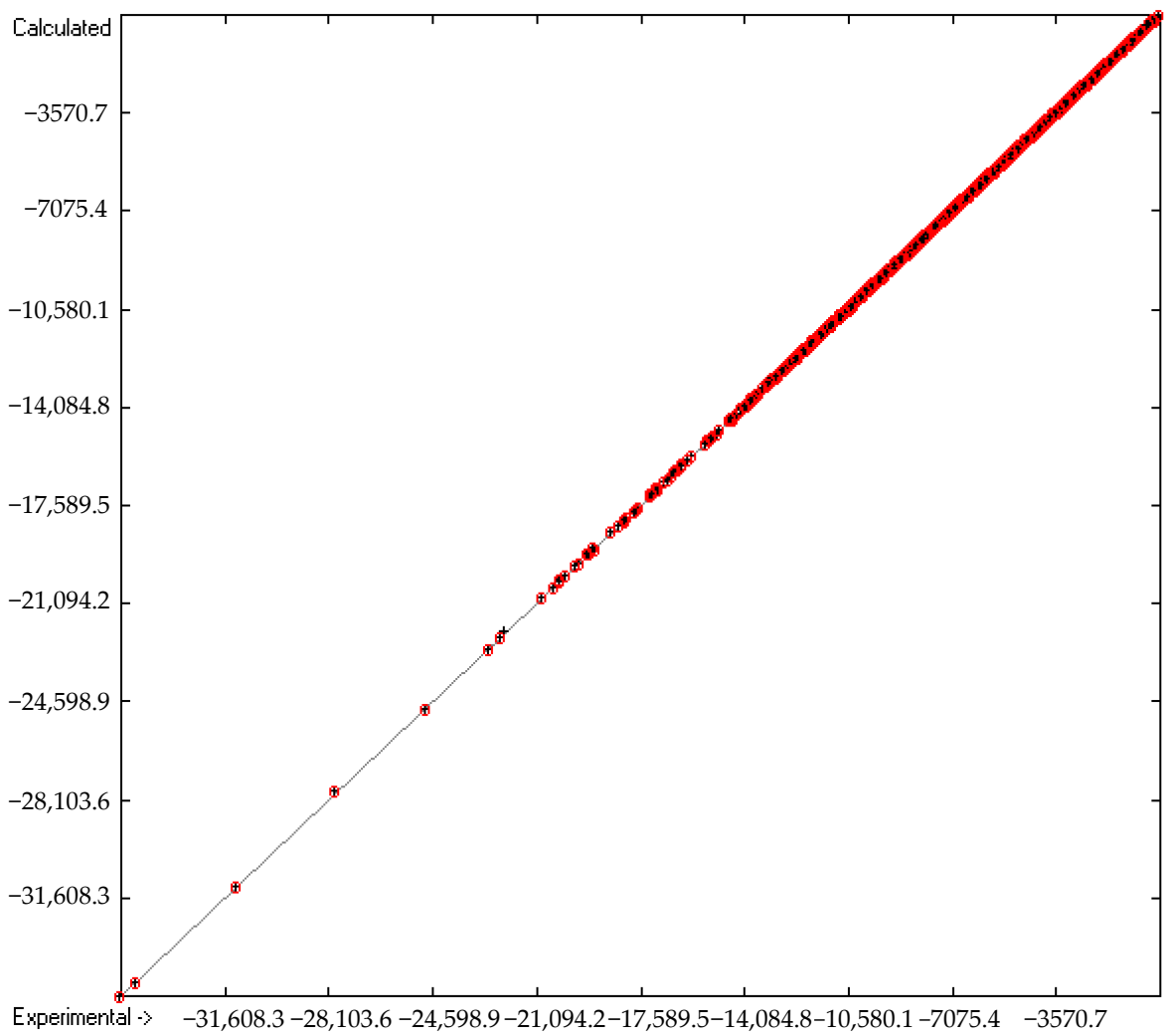

Figure 1. Correlation diagram of the heat-of-combustion data in $\mathrm{kJ} / \mathrm{mol}$. Cross-validation data are added as red circles. (10-fold cross-validated: $\mathrm{N}=4886, \mathrm{Q}^{2}=1$, regression line: intercept $=-1.0111$; slope $=0.9998)$.

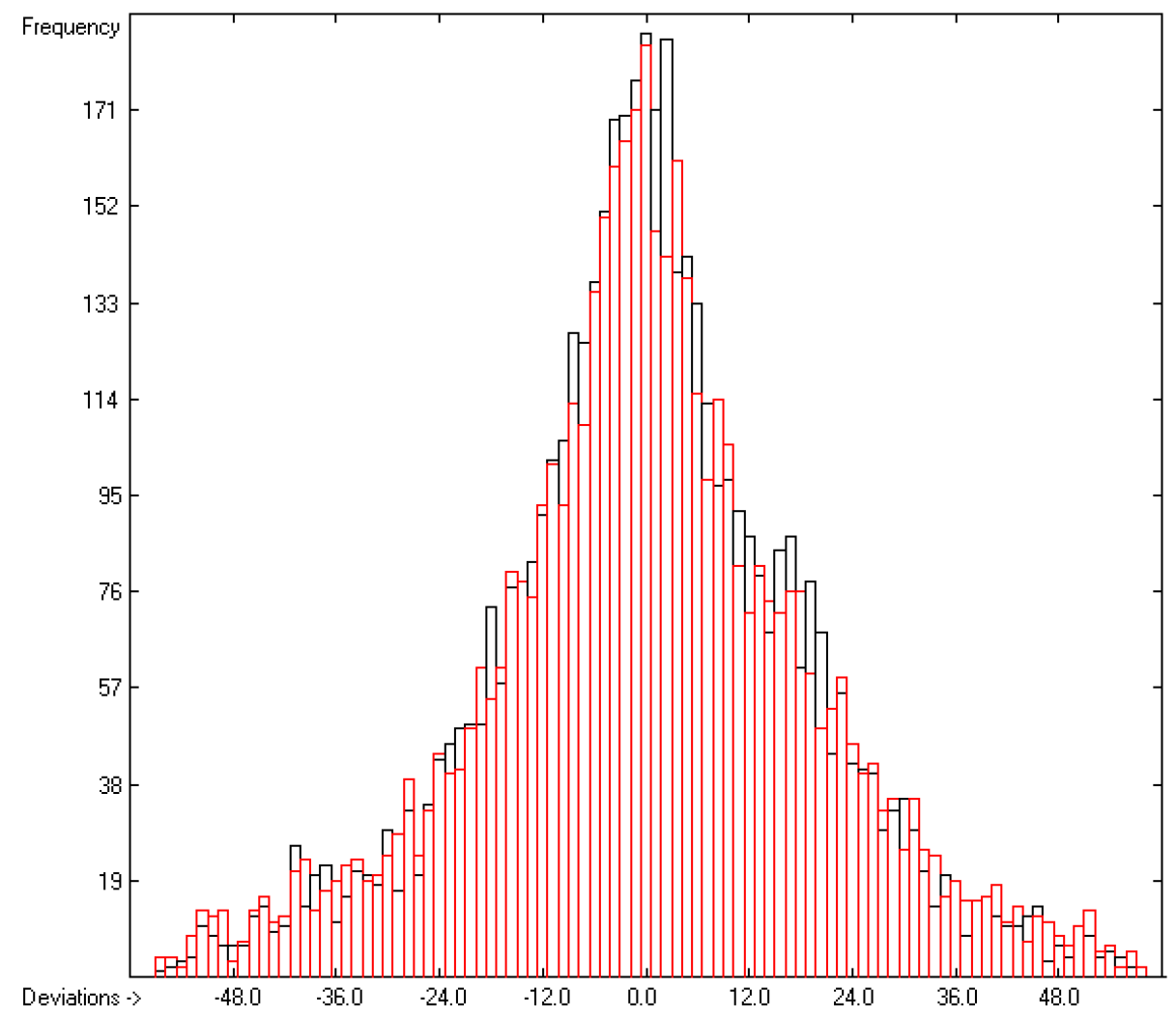

Figure 2. Histogram of the heat-of-combustion data in $\mathrm{kJ} / \mathrm{mol}$. Cross-validation data are superpositioned as red bars. ( $\sigma=18.12 ; S=19.16$; experimental values range from $-35,100$ to -98.2$)$. 


\subsubsection{Amino Acids}

It is common knowledge that amino acids exist in zwitterionic form both in the crystalline as well as the liquid state [527], whereas in the gas phase they exist in their non-ionic form. To our knowledge, the difference in the enthalpies of combustion between these two forms has not yet been systematically analyzed. In Table 5, the calculated values for the non-ionic and zwitter-ionic forms of a series of amino acids are compared with their experimental data.

Table 5. Calculated $\Delta \mathrm{H}^{\circ}$ (c) (in kJ/mol) of Non-ionic and Zwitter-ionic Forms of Amino Acids.

\begin{tabular}{|c|c|c|c|c|c|}
\hline Molecule name & $\begin{array}{c}\Delta \mathrm{H}_{\mathrm{c}}^{\circ} \text { calc } \\
\text { Non-Ionic Form }\end{array}$ & Diff. & $\begin{array}{c}\Delta \mathbf{H}^{\circ}{ }_{\mathrm{c}} \text { calc } \\
\text { Zwitter Form }\end{array}$ & $\Delta \mathrm{H}_{\mathrm{c}}^{\circ} \exp$ & References \\
\hline (L)-Alanine & -1688.7 & -64.9 & -1623.8 & -1621.0 & {$[267,268]$} \\
\hline (L)-Cy(L)-Cysteine & -2316.2 & -64.9 & -2251.3 & -2263.0 & [21] \\
\hline (L)-Cystine & -4373.5 & -132.3 & -4241.2 & -4248.0 & [21] \\
\hline (L)-Histidine & -3230.8 & -64.9 & -3165.9 & -3180.6 & [275] \\
\hline (L)-Hydroxyproline & -2605.5 & -37.9 & -2567.6 & -2594.1 & {$[21]$} \\
\hline (L)-Methionine & -3626.5 & -62.3 & -3564.2 & -3564.1 & [266] \\
\hline 2-Aminobutyric acid & -2342.1 & -62.2 & -2279.9 & -2254.0 & {$[21]$} \\
\hline 2-Methylalanine & -2323.3 & -54.3 & -2269.0 & -2265.9 & [21] \\
\hline 2-Phenylglycine & -4046.5 & -62.2 & -3984.3 & -4005.1 & {$[21]$} \\
\hline 4-Aminobutyric acid & -2345.1 & -57.3 & -2287.8 & -2283.9 & [21] \\
\hline 5-Aminovaleric acid & -2998.5 & -57.3 & -2941.2 & -2937.0 & {$[21]$} \\
\hline 8-Aminocaprylic acid & -4958.9 & -57.3 & -4901.6 & -4884.0 & {$[21]$} \\
\hline Asparagine & -2000.8 & -64.8 & -1936.0 & -1928.5 & {$[265,266,269]$} \\
\hline Aspartic acid & -1674.0 & -64.9 & -1609.1 & -1602.9 & [21] \\
\hline beta-Alanine & -1691.6 & -57.3 & -1634.3 & -1622.9 & {$[21]$} \\
\hline Dopa & -4285.5 & -67.5 & -4218.0 & -4177.8 & [21] \\
\hline epsilon-Aminocaproic acid & -3652.0 & -57.3 & -3594.7 & -3582.2 & [21] \\
\hline Glutamic acid & -2327.7 & -62.2 & -2265.5 & -2277.0 & [21] \\
\hline Glutamine & -2654.6 & -62.3 & -2592.3 & -2572.8 & {$[265,269]$} \\
\hline Glycine & -1038.1 & -57.3 & -980.8 & -978.6 & {$[268,269]$} \\
\hline Isoleucine & -3651.0 & -62.2 & -3588.8 & -3583.7 & [269] \\
\hline Isoserine & -1497.9 & -57.4 & -1440.5 & -1438.2 & [21] \\
\hline Leucine & -3648.4 & -64.9 & -3583.5 & -3581.2 & [269] \\
\hline Norleucine & -3649.1 & -62.3 & -3586.8 & -3582.2 & {$[21]$} \\
\hline$N$-Phenylglycine & -4074.7 & -40.2 & -4034.5 & -4037.6 & {$[21]$} \\
\hline Phenylalanine & -4702.6 & -67.5 & -4635.1 & -4646.3 & [269] \\
\hline Proline & -2798.9 & -56.5 & -2742.4 & -2746.2 & [269] \\
\hline Sarcosine & -1716.2 & -27.4 & -1688.8 & -1675.1 & [270] \\
\hline Serine & -1504.4 & -64.8 & -1439.6 & -1438.9 & [269] \\
\hline Threonine & -2151.3 & -62.2 & -2089.1 & -2087.1 & {$[269,275,277]$} \\
\hline Tryptophane & -5671.0 & -64.9 & -5606.1 & -5629.4 & {$[269,274]$} \\
\hline Tyrosine & -4494.1 & -64.9 & -4429.2 & -4428.1 & [269] \\
\hline Valine & -2994.9 & -62.2 & -2932.7 & -2933.9 & [269] \\
\hline
\end{tabular}


The average $\Delta \mathrm{H}^{\circ}$ (c) difference was calculated as ca. $61.5 \mathrm{~kJ} / \mathrm{mol}$, with the non-ionic form exhibiting the more negative value. Cystine is an outlier in that it contains two aminoacid functions. Interestingly, sarcosine ( $N$-methylglycine) shows the lowest difference between the two forms, which is due to the fact that it carries a less basic dialkylamino group. Similarly, $\mathrm{N}$-phenylglycine differs from the remaining amino acids by an amino group that is conjugated to the phenyl ring, again lowering its basicity. Except for these special cases, the experimental values are in better compliance with the calculated values of the zwitter forms.

\subsubsection{Azo-Hydrazone Tautomerism}

The observation of the hydroxyazo-hydrazone tautomerism is well known among dye chemists dealing with azo dyes, as it has a drastic effect on the electronic absorption spectra. In an earlier paper [1], it was demonstrated that the direction of the tautomeric equilibrium is fairly predictable on the basis of the calculated heats of formation of the hydroxyazo and the hydrazone form. Analogously, the heats of combustion, now founded on a much larger structural basis, should confirm these observations, with the less negative enthalpy indicating the dominating form. Indeed, in conformance with experimental observation, the calculated values listed in Table 6 confirm that arylazo-naphthols primarily exist in their hydrazone form, whereas the opposite is true for the arylazo-naphthylamines. On the other hand, the small enthalpy difference found between the two forms of the phenylazophenols confirms their weak tendency to tautomerize. In addition, the available experimental heats of combustion for 4-phenylazophenol and 4-aminoazobenzene are in fairly good agreement with their prevailing forms.

Table 6. Calculated $\Delta \mathrm{H}^{\circ}(\mathrm{c})$ (in kJ/mol) of Azo and Hydrazone Forms of some Azo Dyes.

\begin{tabular}{|c|c|c|c|c|c|}
\hline Compound & $\begin{array}{c}\text { Hydrazone Form } \\
\Delta \mathbf{H}_{\mathrm{c}} \text { calc }\end{array}$ & $\begin{array}{c}\text { Azo Form } \\
\Delta \mathrm{H}_{\mathrm{c}} \text { calc }\end{array}$ & $\Delta \mathbf{H}_{\mathrm{c}} \exp$ & a & Ref. \\
\hline 4-Phenylazophenol & -6275.2 & -6288.0 & -6314.1 & +- & [528] \\
\hline 2-Phenylazophenol & -6272.3 & -6287.2 & - & +- & [528] \\
\hline 4-Aminoazobenzene & -6651.1 & -6603.1 & -6617.4 & + & [529] \\
\hline 2-Aminoazobenzene & -6648.4 & -6602.4 & & + & \\
\hline 1-Phenylazo-2-naphthol & -8145.8 & -8185.1 & & + & {$[530,531]$} \\
\hline 4-Phenylazo-1-naphthol & -8148.5 & -8185.4 & & + & [532] \\
\hline 1-Phenylazo-2-naphthylamine & -8533.8 & -8500.3 & & + & {$[530,531]$} \\
\hline 4-Phenylazo-1-naphthylamine & -8524.6 & -8503.0 & & + & [533] \\
\hline
\end{tabular}

${ }^{\text {a }}$ Conformance with experimental data.

\subsubsection{Keto-Enol Tautomerism}

Prediction of the dominant forms in keto-enol tautomers under standard conditions has been shown to be at best coincidental in [1], which is not surprising in view of the mostly small enthalpy differences between the two forms. Recalculated values of the heat of combustion of the example molecules in [1], based on the updated group-parameters set, are compared with their experimental values, where available, in Table 7. As is evident, except for acetone, the enol form is supposed to be the dominant tautomer throughout, which clearly contradicts the experience, most prominently with cyclohexanone and cyclopentanone. Beyond this, the experimental values are of no help despite the small standard error $\mathrm{Q}^{2}$ of $19.16 \mathrm{~kJ} / \mathrm{mol}$ (see Table 4) because the deviations between the enthalpies of both forms with the experiment are well within the tolerated boundaries. 
Table 7. Calculated and experimental $\Delta \mathrm{H}^{\circ}$ (c) (in $\mathrm{kJ} / \mathrm{mol}$ ) of Tautomeric Ketones and $\beta$-Diketones.

\begin{tabular}{|c|c|c|c|c|c|}
\hline Compound & $\begin{array}{c}\text { Keto Form } \\
\Delta \mathrm{H}_{\mathrm{c}} \text { ealc }\end{array}$ & $\begin{array}{c}\text { Enol Form } \\
\Delta \mathrm{H}_{\mathrm{c}} \text { ealc }\end{array}$ & $\Delta \mathrm{H}_{\mathrm{c}} \exp$ & $\mathbf{a}$ & Ref. \\
\hline 1-(N-Phenylformimidoyl)-2-naphthol & -8608.3 & -8560.3 & & + & [534] \\
\hline Acetone & -1791.0 & -1798.0 & -1816.5 & + & [535] \\
\hline Cyclohexanone & -3509.3 & -3497.6 & -3517.6 & - & [535] \\
\hline Cyclopentanone & -2865.1 & -2858.1 & -2873.5 & - & [536] \\
\hline Phenol & -3149.4 & -3055.4 & -3055.5 & + & [537] \\
\hline 2-Pyridone & -2557.4 & -2513.2 & -2517.62 & - & [538-540] \\
\hline 4-Pyridone & -2573.8 & -2564.2 & -2537.5 & + & [538-540] \\
\hline Carbostyril & -4461.4 & -4413.7 & -4397.1 & - & [541-543] \\
\hline Acetylacetone & -2686.5 & -2674.5 & -2687.0 & + & [544] \\
\hline Bis(trifluoroacetyl)methane & -1640.7 & -1628.7 & -1673.7 & + & [544] \\
\hline Dibenzoylmethane & -7404.8 & -7394.1 & -7398.5 & + & [544] \\
\hline 1,1-Bis(benzoyl)ethane & -8057.6 & -8036.1 & & - & [544] \\
\hline
\end{tabular}

${ }^{\text {a }}$ Conformance with experimental data.

\subsubsection{Ionic Liquids}

The main extension of the present atom-groups additivity method enabled the inclusion of the heats of combustion of the ionic liquids. Unfortunately, of the 679 ionic liquids presently stored in the database, only for 28 of them was the experimental heat of combustion comparable with calculated values to this date due to the restrictions mentioned earlier. They essentially cover nitrates, dicyanamides, sulfates, dialkyldithiocarbamates, and halogenides of various imidazolium, ammonium, and glycinium cations. In Table 8, these compounds are listed, and their experimental values are compared with the calculated ones. Their conformance is exceptionally good, resulting in a mean absolute deviation of only $0.23 \%$.

Table 8. Calculated and experimental $\Delta \mathrm{H}^{\circ}$ (c) (in $\mathrm{kJ} / \mathrm{mol}$ ) of some Ionic Liquids.

\begin{tabular}{|c|c|c|c|c|}
\hline Molecule Name & $\Delta \mathbf{H}_{\mathrm{c}}^{\circ} \exp$ & $\Delta \mathbf{H}_{\mathrm{c}}^{\circ}$ calc & Deviation & Dev. in \% \\
\hline 1,1,3,3-Tetramethylguanidinium nitrate & -3656.5 & -3656.5 & 0.0 & 0.00 \\
\hline 1-Butyl-1-methylpyrrolidinium dicyanamide & -7244.8 & -7250.1 & 5.3 & -0.07 \\
\hline 1-Butyl-3-methylimidazolium chloride & -5232.3 & -5206.6 & -25.7 & 0.49 \\
\hline 1-Butyl-3-methylimidazolium dicyanoamide & -6273.9 & -6271.6 & -2.3 & 0.04 \\
\hline 1-Butyl-3-methylimidazolium nitrate & -5013.2 & -5017.8 & 4.6 & -0.09 \\
\hline 1-Decyl-3-methylimidazolium bromide & -9105.2 & -9127.4 & 22.2 & -0.24 \\
\hline 1-Dodecyl-3-methylimidazolium bromide & $-10,406.0$ & $-10,434.4$ & 28.4 & -0.27 \\
\hline 1-Ethanol-3-methyl-imidazolium dicyanoamide & -4793.0 & -4780.7 & -12.3 & 0.26 \\
\hline 1-Ethyl-3-methylimidazolium chloride & -3886.2 & -3899.7 & 13.5 & -0.35 \\
\hline 1-Ethyl-3-methylimidazolium dicyanamide & -4955.4 & -4964.7 & 9.3 & -0.19 \\
\hline 1-Ethyl-3-methylimidazolium nitrate & -3697.5 & -3710.9 & 13.4 & -0.36 \\
\hline 1-Methyl-3-pentylimidazolium chloride & -5904.3 & -5860.1 & -44.2 & 0.75 \\
\hline 1-Octyl-3-methylimidazolium bromide & -7837.8 & -7820.5 & -17.3 & 0.22 \\
\hline 1-Tetradecyl-3-methylimidazolium bromide & $-11,718.0$ & $-11,741.3$ & 23.3 & -0.20 \\
\hline $\begin{array}{l}\text { 6,6-(Tetramethylene-3'-oxa)-7a-(nitroxymethyl)-3- } \\
\text { oxoperhydroimidazo [1,5-c]oxazol-6-ium nitrate }\end{array}$ & -5384.8 & -5376.5 & -8.3 & 0.15 \\
\hline $\begin{array}{c}\text { 6,6-(Tetramethylene-3'-oxa)-7a-methyl-3- } \\
\text { oxoperhydroimidazo } \\
\text { [1,5-c]oxazol-6-ium nitrate }\end{array}$ & -5587.5 & -5604.8 & 17.3 & -0.31 \\
\hline
\end{tabular}


Table 8. Cont.

\begin{tabular}{|c|c|c|c|c|}
\hline Molecule Name & $\Delta \mathbf{H}_{\mathrm{c}}^{\circ} \exp$ & $\Delta \mathbf{H}^{\circ}{ }_{c}$ calc & Deviation & Dev. in \% \\
\hline $\begin{array}{l}\text { 6,6-Pentamethylene-7a-(nitroxymethyl)-3- } \\
\text { oxoperhydroimidazo[1,5-c]oxazol-6-ium nitrate }\end{array}$ & -6166.4 & -6159.0 & -7.4 & 0.12 \\
\hline Diethylammonium diethyldithiocarbamate & -7639.6 & -7650.0 & 10.4 & -0.14 \\
\hline Diisobutylammonium diisobutyldithiocarbamate & $-12,891.0$ & $-12,868.4$ & -22.6 & 0.18 \\
\hline Diisopropylammonium diisopropyldithiocarbamate & $-10,260.0$ & $-10,252.6$ & -7.4 & 0.07 \\
\hline Dipropylammonium dipropyldithiocarbamate & $-10,252.0$ & $-10,271.7$ & 19.7 & -0.19 \\
\hline$N, N$-Dimethylglycine bisulfate & -2610.6 & -2604.7 & -5.9 & 0.23 \\
\hline$N, N$-Dimethylglycine methyl ester bisulfate & -3323.2 & -3329.1 & 5.9 & -0.18 \\
\hline$N, N$-Dimethylglycine methyl ester sulfate & -6765.2 & -6790.2 & 25.0 & -0.37 \\
\hline$N, N$-Dimethylglycine sulfate & -5371.6 & -5346.6 & -25.0 & 0.47 \\
\hline Tetraethylammonium nitrate & -5573.4 & -5590.6 & 17.2 & -0.31 \\
\hline Tetramethylammonium nitrate & -2960.5 & -2958.5 & -2.0 & 0.07 \\
\hline Tetra-n-butylammonium nitrate & $-10,841.0$ & $-10,818.4$ & -22.6 & 0.21 \\
\hline
\end{tabular}

\subsection{Heat of Formation}

The heat of formation has been calculated indirectly from the calculated heat of combustion for each compound for which experimental data were available using the heats of combustion for the elements given in [20,21]. Accordingly, the same restrictions concerning "te" valid "ty" of the atom groups as well as the elements themselves apply. Therefore, the number of compounds in the correlation diagram of Figure 3 is identical with that of Figure 1. However, due to the distinctly smaller range of heat-of-formation values from -7238.2 (perfluorohexadecane) to $+1039.7 \mathrm{~kJ} / \mathrm{mol}$ (2,4,6-triazido-s-triazine) and the error-propagation effect, the correlation coefficient $R^{2}$ is "only" 0.9979 , and since the standard error $\sigma$ is still $18.14 \mathrm{~kJ} / \mathrm{mol}$, their mean absolute deviation is $27.23 \%$. The histogram of Figure 4 again confirms the symmetrical Gaussian error distribution of the experimental heats of formation about the calculated ones.

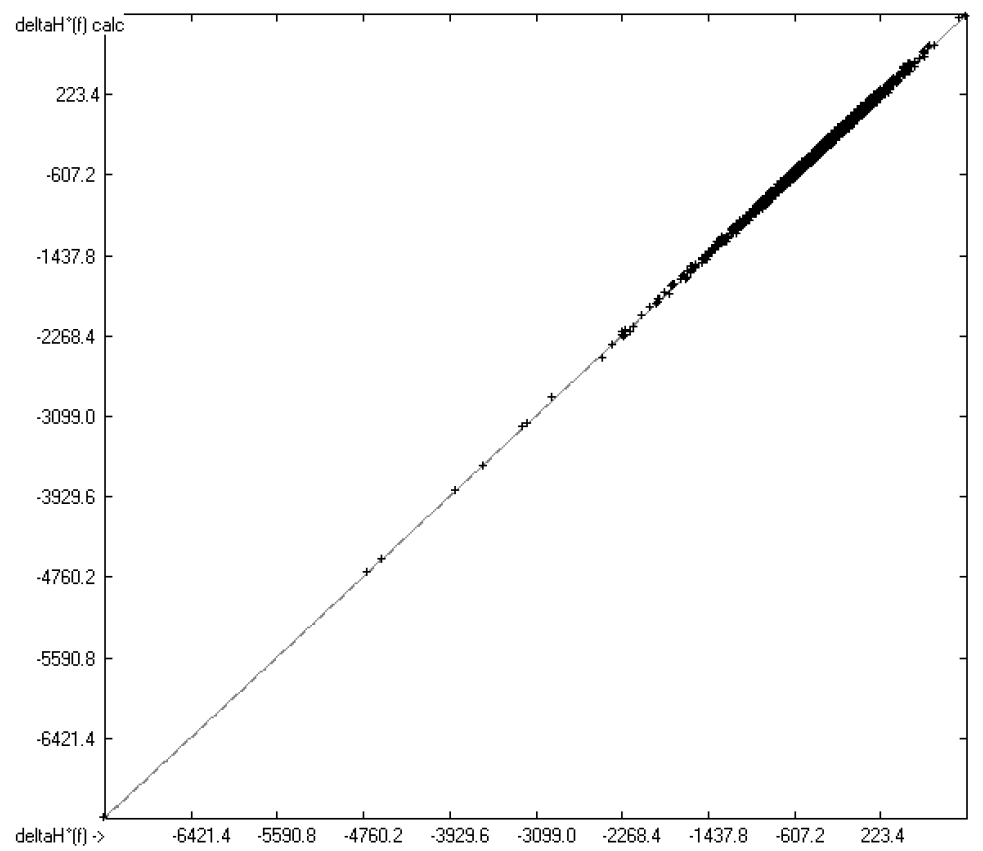

Figure 3. Correlation diagram of the heat of formation (in $\mathrm{kJ} / \mathrm{mol}),\left(\mathrm{N}=4886, \mathrm{R}^{2}=0.9979\right.$, regression line: intercept $=-0.5539$; slope $=0.9979$ ). 


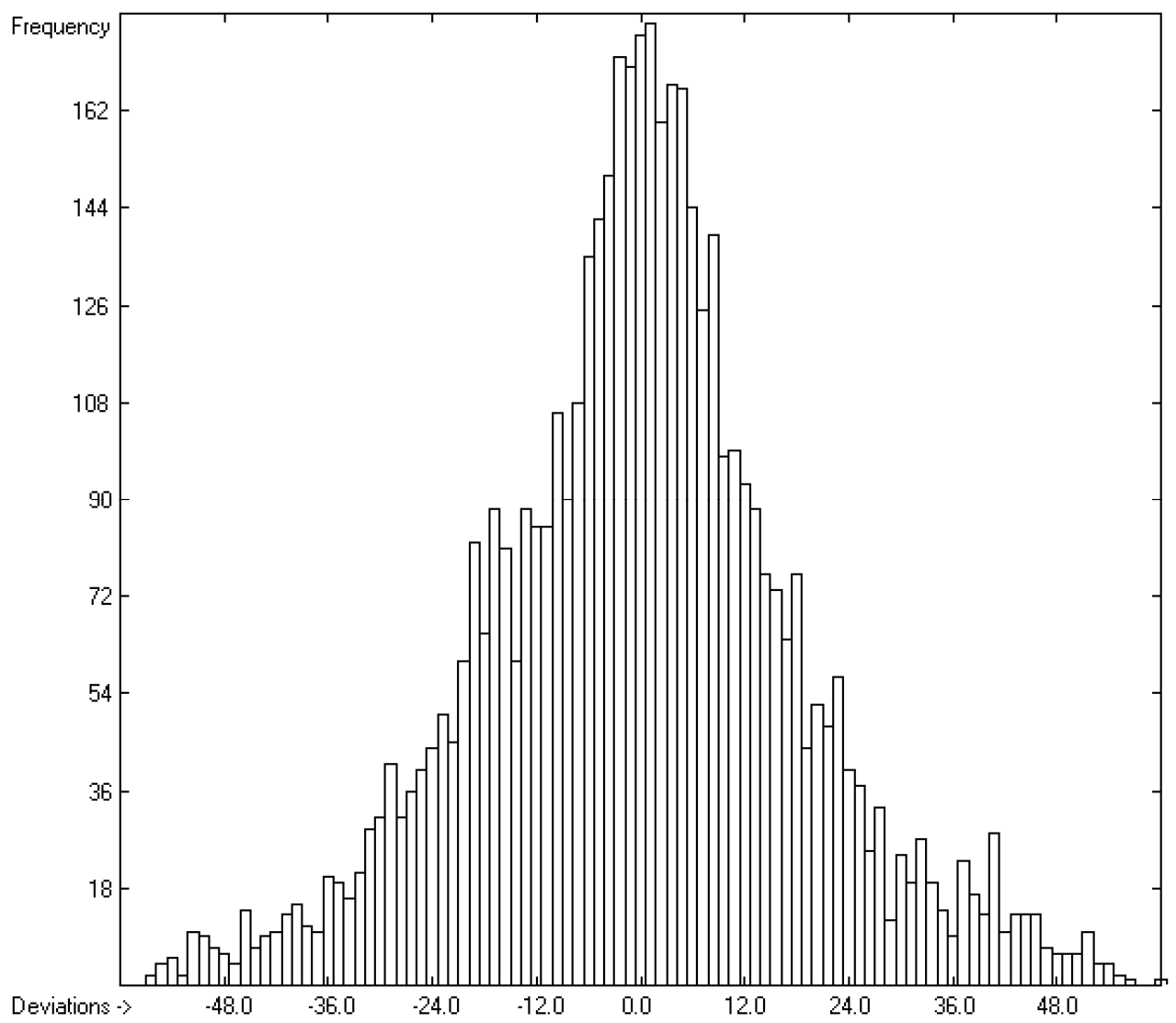

Figure 4. Histogram of the heat of formation (in $\mathrm{kJ} / \mathrm{mol})(\sigma=18.14$; experimental values range from -7238.2 to $+1039.7 \mathrm{~kJ} / \mathrm{mol})$.

\section{Conclusions}

The present paper is proof of the easy expandability of the group-additivity method outlined in [1] for the calculation of the heats of combustion and formation of in principle any organic molecule to consider. A large amount of more than 5000 molecules upon which the atom-group parameters are based allowed strict filtering out of the worst outliers without undue sacrifice of "invalidated" atom groups, resulting in an as-yet unsurpassed accuracy of the predicted heat of combustion with a mean absolute deviation of only $0.4 \%$ for up to $84.5 \%$ of nearly any kind of organic compound. Beyond this, the present method basically allows the accurate calculation of a molecule's heat of combustion simply by means of paper and pencil, using the presented group parameters in Table 4. As this work is ongoing, the number of compounds for which-based on the same algorithmup to 17 physical, thermodynamic, solubility-, optics-, charge-, and environment-related descriptors [1-6] can be reliably predicted, will steadily increase.

The mentioned software project is called ChemBrain IXL, available from Neuronix Software (www.neuronix.ch, Rudolf Naef, Lupsingen, Switzerland).

Supplementary Materials: The following are available online. The list of compounds used in the present work, their experimental data and 3D structures are available online as standard SDF files, accessible for external chemistry software, under the name of "Table S1: Compounds List for deltaH ${ }^{\circ}$ (c) Calculations". The list of the compounds used in the correlation diagrams and histograms containing their names and their experimental and calculated values are available under the names of "Table S2: Experimental vs. calculated deltaH ${ }^{\circ}$ (c) Data Table" and "Table S3: Experimental vs. calculated deltaH ${ }^{\circ}$ (f) Data Table". In addition, the list of outliers is available under the name "Table S4: Outliers of deltaH ${ }^{\circ}$ (c) calculations". Finally, the figures are available as tif files and the tables as doc files under the names given in the text. 
Author Contributions: R.N. developed project ChemBrain and its software upon which this paper is based and also fed the database, calculated and analyzed the results, and wrote the paper. W.E.A.J. suggested the extension of ChemBrain's tool and contributed experimental data and the majority of the literature references. Beyond this, R.N. is indebted to W.E.A.J. for the many valuable discussions. Both authors have read and agreed to the published version of the manuscript.

Funding: This research received no external funding.

Institutional Review Board Statement: Not applicable.

Informed Consent Statement: Not applicable.

Data Availability Statement: The data presented in this study are available in Supplementary Material.

Acknowledgments: R. Naef is indebted to the library of the University of Basel for allowing him full and free access to the electronic literature database.

Conflicts of Interest: The authors declare no conflict of interest.

Sample Availability: Samples of the compounds are not available from the authors.

\section{References}

1. Naef, R. A Generally Applicable Computer Algorithm Based on the Group Additivity Method for the Calculation of Seven Molecular Descriptors: Heat of Combustion, LogPO/W, LogS, Refractivity, Polarizability, Toxicity and LogBB of Organic Compounds; Scope and Limits of Applicability. Molecules 2015, 20, 18279-18351. [CrossRef]

2. Naef, R.; Acree, W.E. Calculation of Five Thermodynamic Molecular Descriptors by Means of a General Computer Algorithm Based on the Group-Additivity Method: Standard Enthalpies of Vaporization, Sublimation and Solvation, and Entropy of Fusion of Ordinary Organic Molecules and Total Phase-Change Entropy of Liquid Crystals. Molecules 2017, 22, 1059. [CrossRef]

3. Naef, R.; Acree, W.E. Application of a General Computer Algorithm Based on the Group-Additivity Method for the Calculation of Two Molecular Descriptors at Both Ends of Dilution: Liquid Viscosity and Activity Coefficient in Water at Infinite Dilution. Molecules 2018, 23, 5. [CrossRef]

4. Naef, R.; Acree, W.E., Jr. Calculation of the Surface Tension of Ordinary Organic and Ionic Liquids by Means of a Generally Applicable Computer Algorithm Based on the Group-Additivity Method. Molecules 2018, 23, 1224. [CrossRef]

5. Naef, R. Calculation of the Isobaric Heat Capacities of the Liquid and Solid Phase Of Organic Compounds at 298.15k by Means of the Group-Additivity Method. Molecules 2020, 25, 1147. [CrossRef]

6. Naef, R.; Acree, W.E., Jr. Calculation of the Vapour Pressure of Organic Molecules by Means of a Group-Additivity Method and their Resultant Gibbs Free Energy and Entropy of Vaporization at 298.15K. Molecules 2021, 26, 1045. [CrossRef]

7. Pauling, L. Nature of the Chemical Bond; Cornell University Press: Ithaca, NY, USA, 1940; pp. 47-58.

8. Klages, F. Über eine Verbesserung der additiven Berechnung von Verbrennungswärmen und der Berechnung der MesomerieEnergie aus Verbrennungswärmen. Chem. Ber. 1949, 82, 358-375. [CrossRef]

9. Wheland, G.W. Theory of Resonance; Wiley: New York, NY, USA, 1944; pp. 52-87.

10. Janecke, E. Die Verbrennungs-und Bildungswärmen Organischer Verbindungen in Beziehung zu Ihrer Zusammensetzung. Z. Elektrochem. 1934, 40, 462-469.

11. Jones, W.H.; Starr, C.E. Determination of Heat of Combustion of Gasolines. Ind. Eng. Chem. Anal. Ed. 1941, 13, 287-290. [CrossRef]

12. Hougen, O.A.; Watson, K.M. Chemical Process Principles Part II; Wiley: New York, NY, USA, 1947; pp. 758-765.

13. Kharash, M.S. Heats of Combustion of Organic Compounds. J. Res. Bur. Stand. 1929, 2, 359-430. [CrossRef]

14. Kharash, M.S.; Sher, B. The Electronic Conception of Valence and Heats of Combustion of Organic Compounds. J. Phys. Chem. 1925, 29, 625-658. [CrossRef]

15. Handrick, G.R. Heats of Combustion of Organic Compounds. Ind. Eng. Chem. 1956, 48, 1366-1374. [CrossRef]

16. Ohlinger, W.S.; Klunzinger, P.E.; Deppmeier, B.J.; Hehre, W.J. Efficient Calculation of Heats of Formation. J. Phys. Chem. A 2009, 113, 2165-2175. [CrossRef]

17. Cohen, N.; Benson, S.W. Estimation of Heats of Formation of Organic Compounds by Additivity Methods. Chem. Rev. 1993, 93, 2419-2438. [CrossRef]

18. Cohen, N. Revised Group Additivity Values for Enthalpies of Formation (at 298 K) of Carbon-Hydrogen and Carbon-HydrogenOxygen Compounds. J. Phys. Chem. Ref. Data 1996, 25, 1411-1481. [CrossRef]

19. Hardtwig, E. Fehler-Und Ausgleichsrechnung; Bibliographisches Institut AG: Mannheim, Germany, 1968.

20. Skinner, H.A. Key Heat of Formation Data. Pure Appl. Chem. 1964, 8, 113-130. [CrossRef]

21. Domalski, E.S. Selected Values of Heats of Combustion and Heats of Formation of Organic Compounds Containing the Elements C, H, N, O, P, and S. J. Phys. Chem. Ref. Data 1972, 1, 221-277. [CrossRef]

22. Lide, D.R. CRC Handbook of Chemistry and Physics, 84th ed.; CRC Press LLC: Boca Raton, FL, USA, 2004.

23. Perrottet, E.; Taub, W.; Briner, E. Sur les États Énergétique Comparatifs des Noyaux Azulénique et Naphthalénique. Helv. Chim. Acta 1940, 23, 1260-1268. [CrossRef] 
24. Prosen, E.J.; Johnson, W.H.; Rossini, F.D. Heats of Formation and Combustion of Normal Alkylcyclpentanes and Cyclohexanes and the Increment per $\mathrm{CH}_{2}$ Group for Several Homologous Series of Hydrocarbons. J. Res. Nat. Bur. Stand. 1946, $37,51-56$. [CrossRef]

25. Dekker, H.; Mosselman, C. Enthalpies of Combustion of 1,1,4,4-Tetramethylcyclodecane and of 1,1,5,5-Tetramethylcyclodecane in the Liquid State. J. Chem. Eng. Data 1978, 23, 111-113. [CrossRef]

26. Clark, T.; Knox, T.; Mc, O.; McKervey, M.A.; Mackle, H.; Rooney, J.J. Thermochemistry of Bridged-Ring Substances. Enthalpies of Formation of Some Diamondoid Hydrocarbons and of Perhydroquinacene. Comparisons with Data from Empirical Force Field Calculations. J. Am. Chem. Soc. 1979, 101, 2404-2410. [CrossRef]

27. Jochems, R.; Dekker, H.; Mosselman, C.; Somsen, G. Enthalpies of Formation of Bicyclo[3.3.1]Non-2-Ene, Bicyclo[3.2.2]Non-6-Ene, and Bicyclo[4.2.1]Non-3-Ene. J. Chem. Thermodyn. 1983, 15, 95-99. [CrossRef]

28. Domalski, E.S.; Hearing, E.D. Estimation of the Thermodynamic Properties of Hydrocarbons at 298.15K. J. Phys. Chem. Ref. Data 1988, 17, 1637-1678. [CrossRef]

29. Chirico, R.D.; Knipmeyer, S.E.; Nguyen, A.; Steele, W.V. The Thermodynamic Properties of Biphenyl. J. Chem. Thermodyn. 1989, 21, 1307-1331. [CrossRef]

30. Steele, W.V.; Chirico, R.D.; Smith, N.K. The Standard Enthalpies of Formation of 2-Methylbiphenyl and Diphenylmethane. J. Chem. Thermodyn. 1995, 27, 671-678. [CrossRef]

31. Ribeiro da Silva, M.A.V.; Matos, M.A.R.; do Rio, C.M.A.; Morais, V.M.F. Thermochemical and Theoretical Studies of 4Methylbiphenyl, 4,4'-Dimethylbiphenyl, 4,4'-Dimethyl-2,2'-Bipyridine. J. Chem. Soc. Faraday Trans. 1997, 93, $3061-3065$. [CrossRef]

32. Melkhanova, S.V.; Pimenova, S.M.; Kolesov, V.P.; Pimerzin, A.A.; Sarkisova, V.S. The Standard Molar Enthalpies of Formation of Some Alkyladamantanes. J. Chem. Thermodyn. 2000, 32, 1311-1317. [CrossRef]

33. Pimenova, S.M.; Melkhanova, S.V.; Kolesov, V.P.; Lobach, A.S. The Enthalpy of Formation and C-H Bond Enthalpy of Hydrofullerene $\mathrm{C}_{60} \mathrm{H}_{36}$. J. Phys. Chem. B 2002, 106, 2127-2130. [CrossRef]

34. Rojas-Aguilar, A. Enthalpies of Combustion and Formation of Fullerene $\mathrm{C}_{70}$ by Isoperibolic Combustion Calorimetry. J. Chem. Thermodyn. 2004, 36, 519-523. [CrossRef]

35. Rojas-Aguilar, A.; Martinez-Herrera, M. Enthalpies of Combustion and Formation of Fullerenes by Micro-Combustion Calorimetry in a Calvet Calorimeter. Thermochim. Acta 2005, 437, 126-133. [CrossRef]

36. Ribeiro da Silva, M.A.V.; Amaral, L.M.P.F.; Santos, A.F.L.O.M.; Gomes, J.R. Thermochemistry of Some Alkylsubstituted Anthracenes. J. Chem. Thermodyn. 2006, 38, 367-375. [CrossRef]

37. Santos, R.C.; Bernardes, C.E.S.; Diogo, H.P.; Piedade, M.F.M.; Canongia Lopes, J.N.; Minas de Piedade, M.E. Energetics of the Thermal Dimerization of Acenaphthylene to Heptacyclene. J. Phys. Chem. A 2006, 110, 2299-2307. [CrossRef]

38. Rojas, A.; Martinez, M.; Amador, P.; Torres, L.A. Increasing Stability of the Fullerenes with the Number of Carbon Atoms: The Experimental Evidence. J. Phys. Chem. B 2007, 111, 9031-9035. [CrossRef] [PubMed]

39. Roux, M.V.; Temprado, M.; Chickos, J.S.; Nagano, Y. Critically Evaluated Thermochemical Properties of Polycyclic Aromatic Hydrocarbons. J. Phys. Chem. Ref. Data 2008, 37, 1855-1996. [CrossRef]

40. Santos, R.C.; Leal, J.P.; Simoes, J.A.M. Additivity Methods for Prediction of Thermochemical Properties. The Laidler Method Revisited. 2. Hydrocarbons Including Substituted Cyclic Compounds. J. Chem. Thermodyn. 2009, 41, 1356-1373. [CrossRef]

41. Martinez, M.; Torres, L.A.; Campos, M.; Rojas, A. Heat of Functionalization of a Methanofullerene Derivative from Microcalorimetric Combustion Measurements. J. Phys. Chem. C 2009, 113, 13527-13531. [CrossRef]

42. Alberty, R.A. Standard Chemical Thermodynamic Properties of Alkylbenzene Isomer Groups. J. Phys. Chem. Ref. Data 1985, 14, 177-192. [CrossRef]

43. Melkhanova, S.V.; Pimenova, S.M.; Chelovskaya, N.V.; Miroshnichenko, E.A.; Pashchenko, L.L.; Nesterov, I.A.; Naumkin, P.V. Thermochemical Studies of 4-Tert-Butylbiphenyl and 4,40-Di-Tert-Butylbiphenyl. J. Chem. Thermodyn. 2009, 41, 651-653. [CrossRef]

44. Verevkin, S.P.; Emel'yanenko, V.N.; Toktonov, A.V. Thermochemistry of Ionic Liquid Catalyzed Reactions. Experimental and Theoretical Study of Chemical Equilibria of Izomerization and Transalkylation of Tert-Amylbenzenes. J. Phys. Chem. B 2009, 113, 12704-12710. [CrossRef] [PubMed]

45. Ribeiro da Silva, M.A.V.; Santos, L.M.N.B.F.; Lima, L.M.S.S. Thermodynamic Study of 1,2,3-Triphenylbenzene and 1,3,5Triphenylbenzene. J. Chem. Thermodyn. 2010, 42, 134-139. [CrossRef]

46. Lima, C.F.R.A.C.; Rocha, M.A.A.; Melo, A.; Gomes, L.R.; Low, J.N.; Santos, L.M.N.B.F. Structural and Thermodynamic Characterization of Polyphenylbenzenes. J. Phys. Chem. A 2011, 115, 11876-11888. [CrossRef]

47. Lima, C.F.R.A.C.; Rocha, M.A.A.; Schröder, B.; Gomes, L.R.; Low, J.N.; Santos, L.M.N.B.F. Phenylnaphthalenes: Sublimation Equilibrium, Conjugation, and Aromatic Interactions. J. Phys. Chem. B 2012, 116, 3557-3570. [CrossRef]

48. Monte, M.J.S.; Notario, R.; Pinto, S.P.; Lobo Ferreira, A.I.M.C.; Ribeiro da Silva, M.D.M.C. Thermodynamic Properties of Fluoranthene: An Experimental and Computational Study. J. Chem. Thermodyn. 2012, 49, 159-164. [CrossRef]

49. Sousa, C.C.S.; Matos, M.A.R.; Morais, V.M.F. Energetics and Stability of Azulene: From Experimental Thermochemistry to High-Level Quantum Chemical Calculations. J. Chem. Thermodyn. 2014, 73, 101-109. [CrossRef]

50. Chirico, R.D.; Steele, W.V.; Kazakov, A.F. Thermodynamic Properties of 1-Phenylnaphthalene and 2-Phenylnaphthalene. J. Chem. Thermodyn. 2014, 73, 241-254. [CrossRef] 
51. Abhoud, J.-M.M.; Alkorta, I.; Davalos, J.Z.; Koppel, I.A.; Koppel, I.; Lenoir, D.; Martinez, S.; Mishima, M. The Thermodynamic Stability of Adamantylideneadamantane and Its Proton- and Electron-Exchanges. Comparison with Simple Alkenes. Bull. Chem. Soc. Jpn. 2016, 89, 762-769. [CrossRef]

52. Oliveira, J.A.S.A.; Freitas, V.L.S.; Motario, R.; Ribeiro da Silva, M.D.M.C.; Monte, M.J.S. Thermodynamic Properties of 2,7-Di-TertButylfluorene-An Experimental and Computational Study. J. Chem. Thermodyn. 2016, 101, 115-122. [CrossRef]

53. Santos, A.F.L.O.M.; Oliveira, J.A.S.A.; Ribeiro da Silva, M.D.M.C.; Monte, M.J.S. Vapor Pressures, Thermodynamic Stability, and Fluorescence Properties of Three 2,6-Alkyl Naphthalenes. Chemosphere 2016, 146, 173-181. [CrossRef]

54. Lima, C.F.R.A.C.; Rodrigues, A.S.M.C.; Santos, L.M.N.B.F. Effect of Confined Hindrance in Polyphenylbenzenes. J. Phys. Chem. A 2017, 121, 2475-2481. [CrossRef] [PubMed]

55. Lima, C.F.R.A.C.; Costa, J.C.S.; Lima, L.M.S.S.; Melo, A.; Silva, A.M.S.; Santos, L.M.N.B.F. Energetic and Structural Insights into the Molecular and Supramolecular Properties of Rubrene. ChemistrySelect 2017, 2, 1759-1769. [CrossRef]

56. Gheorghe, D.; Neacsu, A.; Perisanu, S. Thermochemistry of Eight Membered Ring Hydrocarbons. The Enthalpy of Formation of Cyclooctane. Rev. Chim. 2020, 71, 507-515. [CrossRef]

57. Pimenova, S.M.; Lukyanova, V.A.; Druzhinina, A.I.; Dorofeeva, O.V. Thermodynamic Properties of 1,3,3-Trimethylcyclopropene. J. Chem. Thermodyn. 2020, 151, 106240. [CrossRef]

58. Costa, J.C.S.; Campos, R.M.; Lima, L.M.S.S.; Ribeiro da Silva, M.A.V.; Santos, L.M.N.B.F. On the Aromatic Stabilization of Fused Polycyclic Aromatic Hydrocarbons. J. Phys. Chem. A 2021, 125, 3696-3709. [CrossRef] [PubMed]

59. Pimenova, S.M.; Lukyanova, V.A.; Druzhinina, A.I.; Miroshnichenko, E.A. Standard Enthalpies of Formation of Some Phenyl Derivatives of Cyclopropene. J. Chem. Thermodyn. 2021, 161, 106538. [CrossRef]

60. Konnova, M.E.; Vostrikov, S.V.; Pimerzin, A.A.; Verevkin, S.P. Thermodynamic Analysis of Hydrogen Storage: Biphenyl as Affordable Liquid Organic Hydrogen Carrier (LOHC). J. Chem. Thermodyn. 2021, 159, 106455. [CrossRef]

61. Mosselman, C.; Dekker, H. Enthalpies of Formation of n-alkan-1-ols. J. Chem. Soc. Faraday Trans. I 1975, 71, 417-424. [CrossRef]

62. Ribeiro da Silva, M.A.V.; Cabral, J.I.T.A. Standard Molar Enthalpies of Formation of 1-Methyl-2-Piperidinemethanol, 1-Piperidineethanol, and 2-Piperidineethanol. J. Chem. Thermodyn. 2006, 38, 1461-1466. [CrossRef]

63. Pinto, S.S.; Bernardes, C.E.S.; Diogo, H.P.; Minas da Piedade, M.E. Thermochemistry of 2- and 4-biphenylmethanol. J. Chem. Thermodyn. 2007, 39, 1384-1391. [CrossRef]

64. Ribeiro da Silva, M.A.V.; Lobo Ferreira, A.I.M.C. Experimental Standard Molar Enthalpies of Formation of Some Methylbenzenediol Isomers. J. Chem. Thermodyn. 2009, 41, 1096-1103. [CrossRef]

65. Davalos, J.Z.; Herrero, R.; Costa, J.C.S.; Santos, L.M.N.B.F.; Liebman, J.F. Energetic and Structural Study of Bisphenols. J. Phys. Chem. A 2014, 118, 3705-3709. [CrossRef]

66. Zaitsau, D.; Paulechka, E.; Firaha, D.S.; Blokhin, A.V.; Kabo, G.J.; Bazyleva, A.; Kabo, A.G.; Varfolomeev, M.A.; Sevruk, V.M. Comprehensive Study of the Thermodynamic Properties for 2-Methyl-3-Buten-2-Ol. J. Chem. Thermodyn. 2015, 91, 459-473. [CrossRef]

67. Freitas, V.L.S.; Lima, A.C.M.O.; Sapei, E.; Ribeiro da Silva, M.D.M.C. Comprehensive Thermophysical and Thermochemical Studies of Vanillyl Alcohol. J. Chem. Thermodyn. 2016, 102, 287-292. [CrossRef]

68. Dávalos, J.Z.; Guerrero, A.; Valderrama-Negrón, A.C.; Romero, V.; Lago, A.F. Energetics and Structural Properties of Neutral and Deprotonated Phenyl Carbinols. J. Chem. Thermodyn. 2016, 97, 315-321. [CrossRef]

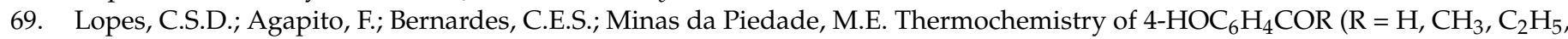
$\mathrm{n}-\mathrm{C}_{3} \mathrm{H}_{7}, \mathrm{n}-\mathrm{C}_{4} \mathrm{H}_{9}, \mathrm{n}-\mathrm{C}_{5} \mathrm{H}_{11}$, and $\mathrm{n}-\mathrm{C}_{6} \mathrm{H}_{13}$ ) Compounds. J. Chem. Thermodyn. 2017, 104, 281-287. [CrossRef]

70. Knyazev, A.V.; Emel'yanenko, V.N.; Shipilova, A.S.; Zaitsau, D.H.; Lelet, M.I.; Knyazeva, S.S.; Gusarova, E.V.; Varfolomeev, M.A. Thermodynamic Properties of Myo-Inositol. J. Chem. Thermodyn. 2018, 116, 76-84. [CrossRef]

71. Davalos, J.Z.; Valderrama-Negron, A.C.; Barrios, J.; Freitas, V.L.S.; Ribeiro da Silva, M.D.M.C. Energetic and Structural Properties of Two Phenolic Antioxidants: Tyrosol and Hydroxytyrosol. Phys. Chem. A 2018, 122, 4130-4137. [CrossRef] [PubMed]

72. Feng, J.; Shang, Y.; Zhang, Y. Research on Synthesis and Thermodynamic Properties of 2-Methoxycyclohexanol. J. Therm. Anal. Calorim. 2018, 131, 2197-2203. [CrossRef]

73. Carvalho, T.M.T.; Amaral, L.M.P.F.; Morais, V.M.F.; Ribeiro da Silva, M.D.M.C. Calorimetric and Computational Study of (1H-Indol-n-yl)Methanol and 2-(1H-Indol-n-yl)Ethanol ( $\mathrm{n}=2,3)$. Thermochim. Acta 2019, 673, 169-176. [CrossRef]

74. Freitas, V.L.S.; Ribeiro da Silva, M.D.M.C. Structural and Energetic Insights on Two Dye Compounds: 1-Acetyl-2-Naphthol and 2-Acetyl-1-Naphthol. Molecules 2020, 25, 3827. [CrossRef] [PubMed]

75. Pilcher, G.; Skinner, H.A.; Pell, A.S.; Pope, A.E. Measurements of Heats of Combustion by Flame Calorimetry. Part 1-Diethyl Ether, Ethyl Vinyl Ether and Divinyl Ether. Trans. Faraday Soc. 1963, 59, 316-330. [CrossRef]

76. Pilcher, G.; Pell, A.S.; Coleman, D.J. Measurements of Heats of Combustion by Flame Calorimetry. Part 2-Dimethyl Ether, Methyl Ethyl Ether, Methyl n-Propyl Ether, Methyl isoPropy1 Ether. Trans. Faraday Soc. 1964, 60, 499-505. [CrossRef]

77. Ribeiro da Silva, M.A.V.; Lobo Ferreira, A.I.M.C.; Cimas, A. Experimental and Computational Study on the Molecular Energetics of Benzyloxyphenol Isomers. J. Chem. Thermodyn. 2011, 43, 1857-1864. [CrossRef]

78. Druzhinina, A.I.; Pimenova, S.M.; Tarazanov, S.V.; Nesterova, T.N.; Varushchenko, R.M. Thermodynamic Properties of 4-TertButyl-Diphenyl Oxide. J. Chem. Thermodyn. 2015, 87, 69-77. [CrossRef]

79. Sinditski, V.P.; Burzhava, A.V.; Chernyi, A.N.; Shmelev, D.S.; Apalkova, V.N.; Palysaeva, N.V.; Sheremetev, A.B. A Comparative Study of Two Difurazanyl Ethers. J. Therm. Anal. Calorim. 2016, 123, 1431-1438. [CrossRef] 
80. Freitas, V.L.S.; Gomes, J.R.B.; Ribeiro da Silva, M.D.M.C. Thermochemical Studies on Two Alkyl-Bulky Substituted Xanthene Derivatives: 9,9-Dimethylxanthene and 2,7-Di-Tert-Butyl-9,9-Dimethylxanthene. J. Chem. Thermodyn. 2017, 106, 168-177. [CrossRef]

81. Verevkin, S.P.; Siewert, R.; Emel'yanenko, V.N.; Bara, J.E.; Cao, H.; Pimerzin, A.A. Diphenyl Ether Derivatives as Potential Liquid Organic Hydrogen Carriers: Thermochemical and Computational Study. J. Chem. Eng. Data 2020, 65, 1108-1116. [CrossRef]

82. Verevkin, S.P.; Pimerzin, A.A.; Sun, L.-X. Liquid Organic Hydrogen Carriers: Hydrogen Storage by Di-Phenyl Ether Derivatives: An Experimental and Theoretical Study. J. Chem. Thermodyn. 2020, 144, 106057. [CrossRef]

83. Verevkin, S.P.; Pimerzin, A.A.; Sun, L.-X. Structure-Property Relationships in Substituted Diphenyl Ethers: Non-Nearest Interactions of Methyl-, Methoxy-, Hydroxyl-, Amino-, and Nitro-Substituents. Fluid Phase Equil. 2020, 512, 112534. [CrossRef]

84. Verevkin, S.P.; Turovtsev, V.V.; Andreeva, I.V.; Orlov, Y.D.; Pimerzin, A.A. Webbing a Network of Reliable Thermochemistry Around Lignin Building Blocks: Tri-Methoxybenzenes. R. Soc. Chem. Adv. 2021, 11, 10727. [CrossRef]

85. Flores, H.; Lopez, Y.I.; Amador, P. Enthalpies of Combustion and Formation of 3-Formylchromones. Thermochim. Acta 2006, 450, 35-37. [CrossRef]

86. Daniela, A.A.; Mariela, P.I.; Jorge, R.M.; Nelly, J.L.; Vara, G.; Manuel, E.; Eduardo, C.A.; Alicia, J.H. Experimental and Theoretical Standard Enthalpies of Formation of 3,6-Dibutanal-1,2,4,5-Tetroxane. Glob. J. Mol. Sci. 2007, 2, 8-11.

87. Ribeiro da Silva, M.A.V.; Santos, A.F.L.O.M. Energetics of Thiophenecarboxaldehydes and Some of its Alkyl Derivatives. J. Chem. Thermodyn. 2008, 40, 917-923. [CrossRef]

88. Ribeiro da Silva, M.D.M.C.; Gonçalves, M.V.; Monte, M.J.S. Thermodynamic Study on Hydroxybenzaldehyde Derivatives: 3- and 4-Hydroxybenzaldehyde Isomers and 3,5-Di-Tert-Butyl-2-Hydroxybenzaldehyde. J. Chem. Thermodyn. 2010, 42, 472-477. [CrossRef]

89. Santos, A.F.L.O.M.; Oliveira, J.A.S.A.; Monte, M.J.S. Experimental and Computational Thermodynamics of Pyrene and 1-Pyrenecarboxaldehyde and Their Photophysical Properties. J. Chem. Thermodyn. 2015, 90, 282-293. [CrossRef]

90. Amaral, L.M.P.F.; Freitas, V.L.S.; Goncalves, J.F.R.; Barbosa, M.; Chickos, J.S.; Ribeiro da Silva, M.D.M.C. The Influence of the Hydroxy and Methoxy Functional Groups on the Energetic and Structural Properties of Naphthaldehyde as Evaluated by Both Experimental and Computational Methods. Struct. Chem. 2015, 26, 137-149. [CrossRef]

91. Dibrivnyi, V.; Sobechko, I.; Puniak, M.; Horak, Y.; Obushak, M.; Van-Chin-Syan, Y.; Andriy, M.; Velychkivska, N. Thermodynamic Properties of 5(Nitrophenyl) Furan-2-Carbaldehyde Isomers. Chem. Cent. J. 2015, 9, 67. [CrossRef] [PubMed]

92. Oliveira, J.A.S.A.; Notario, R.; Ribeiro da Silva, M.D.M.C.; Monte, M.J.S. Vapour Pressures, Enthalpies and Gibbs Energies of Formation and Sublimation of Fluorene-2-Carboxaldehyde. J. Chem. Thermodyn. 2017, 111, 65-71. [CrossRef]

93. Ximello, A.; Ramos, F.; Rojas, A.; Hernandez-Perez, J.M.; Camarillo, E.A.; Solano-Altamirano, J.M.; Sandoval-Lira, J.; Flores, H. Experimental and Theoretical Thermochemical Study of Nitrobenzaldehyde Isomers. J. Chem. Eng. Data 2020, 65, 4935-4945. [CrossRef]

94. Siewert, R.; Samatov, A.A.; Nagrimanov, R.N.; Verevkin, S.P. Thermochemistry of Di-Substituted Benzenes: Nitro- and Dimethylamino Benzaldehydes. J. Chem. Thermodyn. 2020, 143, 106060. [CrossRef]

95. Ribeiro da Silva, M.A.V.; Ribeiro da Silva, M.D.M.C.; Teixeira, J.A.S.; Bruce, J.M.; Guyan, P.M.; Pilcher, G. Enthalpies of Combustion of 1,4-Naphthoquinone, 9,10-Anthraquinone, 9,10-Phenanthraquinone, 1,4,9,10-Anthradiquinone, 5,8-Dihydroxy1,4-Naphthoquinone, and 1,4-Dihydroxy-9,10-Nthraquinone. J. Chem. Thermodyn. 1989, 21, 265-274. [CrossRef]

96. Verevkin, S.P. Thermochemistry of Aromatic Ketones. Experimental Enthalpies of Formation and Structural Effects. Thermochim. Acta 1998, 310, 229-235. [CrossRef]

97. Ribeiro da Silva, M.A.V.; Ferrao, M.L.C.C.H.; Monte, M.J.S.; Goncalves, J.M.; Jiye, F. Standard Molar Enthalpy of Formation, Vapour Pressures, and Standard Molar Enthalpy of Sublimation of Benzanthrone. J. Chem. Thermodyn. 1999, 31, $1067-1075$. [CrossRef]

98. Jimenez, P.; Roux, M.V.; Davalos, J.Z.; Molina, M.T. Thermochemistry of 9-Hydroxy-1,4-Anthraquinone and 9-Methoxy-1,4Anthraquinone. J. Chem. Thermodyn. 2002, 34, 1117-1126. [CrossRef]

99. Perisanu, S.; Contineanu, I.; Banciu, M.D.; Liebman, J.F.; Farivar, B.S.; Mullan, M.A.; Chickos, J.S.; Rath, N.; Hillesheim, D.M. The Enthalpies of Formation of Two Dibenzocyclooctadienones. Thermochim. Acta 2003, 400, 109-120. [CrossRef]

100. Ribeiro da Silva, M.A.V.; Santos, L.M.N.B.F. Standard Molar Enthalpy of Formation of Monothiodibenzoylmethane by RotatingBomb Calorimetry. J. Chem. Thermodyn. 2004, 36, 447-451. [CrossRef]

101. Perisanu, S.; Contineanu, I.; Banciu, M.D.; Zhao, H.; Rath, N.; Chickos, J.S. The Structure and Thermochemistry of 3:4,5:6Dibenzo-2-Hydroxymethylene-Cyclohepta-3,5-Dienenone (1) and Some Related Compounds. Struct. Chem. 2006, 17, 639-648. [CrossRef]

102. Matos, M.A.R.; Sousa, C.C.S.; Morais, V.M.F. Experimental and Theoretical Thermochemistry of $\beta$-Tetralone. J. Chem. Thermodyn. 2008, 40, 1552-1557. [CrossRef]

103. Matos, M.A.R.; Sousa, C.C.S.; Morais, V.M.F. Thermochemical Study of Some Methoxytetralones. J. Chem. Thermodyn. 2009, 41, 69-73. [CrossRef]

104. Miranda, M.S.; Morais, V.M.F.; Matos, M.A.R.; Liebman, J.F. Standard Molar Enthalpy of Formation of 1-Benzosuberone: An Experimental and Computational Study. J. Chem. Thermodyn. 2010, 42, 1094-1100. [CrossRef]

105. Amaral, L.M.P.F.; Ribeiro da Silva, M.A.V. Calorimetric Study of 2'-Methylacetophenone and 4'-Methylacetophenone. J. Chem. Thermodyn. 2013, 57, 301-305. [CrossRef] 
106. Amaral, L.M.P.F.; Morais, V.M.F.; Ribeiro da Silva, M.A.V. Standard Molar Enthalpy of Formation of Methoxyacetophenone Isomers. J. Chem. Thermodyn. 2014, 74, 22-31. [CrossRef]

107. Freitas, V.L.S.; Ferreira, P.J.O.; Ribeiro da Silva, M.D.M.C. Experimental and Computational Thermochemical Studies of Acridone and N-Methylacridone. J. Chem. Thermodyn. 2018, 118, 115-126. [CrossRef]

108. Emel'yanenko, V.N.; Varfolomeev, M.A.; Novikov, V.B.; Turovtsev, V.V.; Orlov, Y.D. Thermodynamic Properties of 1,4Benzoquinones in Gaseous and Condensed Phases: Experimental and Theoretical Studies. J. Chem. Eng. Data 2017, 62, $2413-2422$. [CrossRef]

109. Silva, A.L.R.; Lima, A.C.M.O.; Ribeiro da Silva, M.D.M.C. Energetic Characterization of Indanone Derivatives Involved in Biomass Degradation. J. Therm. Anal. Calorim. 2018, 134, 1267-1276. [CrossRef]

110. Silva, A.L.R.; Moura, C.; Ribeiro da Silva, M.D.M.C. Energetic vs Structural Study of Two Biomass Degradation Derivatives: 2-Cyclopentenone and 3-Methyl-2-Cyclopentenone. J. Chem. Thermodyn. 2019, 132, 390-396. [CrossRef]

111. Amaral, L.M.P.F.; Ribeiro da Silva, M.A.V. Experimental and Computational Thermochemical Study of Dimethoxyacetophenones. J. Chem. Thermodyn. 2021, 152, 106257. [CrossRef]

112. Pashanova, K.I.; Poryunova, P.E.; Sologubov, S.S.; Markin, A.V.; Smirnova, N.N.; Piskuno, A.V. Standard Thermochemical Characteristics of Combustion and Formation of Bulky Benzoquinone-Type Derivatives at T = 298.15 K. J. Chem. Eng. Data 2021, 66, 1970-1976. [CrossRef]

113. Ribeiro da Silva, M.A.V.; Ferrao, M.L.C.C.H.; Alves da Silva, A.M.R.O. Standard Molar Enthalpies of Formation of Three Branched Alkyl Carboxylic Acids. J. Chem. Thermodyn. 1999, 31, 1129-1134. [CrossRef]

114. Kirklin, D.R. Enthalpy of Combustion of Acetylsalicylic Acid. J. Chem. Thermodyn. 2000, 32, 701-709. [CrossRef]

115. Matos, M.A.R.; Monte, M.J.S.; Hillesheim, D.M. Standard Molar Enthalpies of Combustion of Five Trans-Dimethoxycinnamic Acids. J. Chem. Thermodyn. 2001, 33, 899-903. [CrossRef]

116. Temprado, M.; Roux, M.V.; Jimenez, P.; Davalos, J.Z.; Notario, R. Experimental and Computational Thermochemistry of 2- and 3-Thiophenecarboxylic Acids. J. Phys. Chem. A 2002, 106, 11173-11180. [CrossRef]

117. Matos, M.A.R.; Morais, V.M.F.; Ribeiro da Silva, M.D.M.C.; Marques, M.C.F.; Sousa, E.A.; Castineiras, J.P.; Santos, C.P.; Acree, W.E., Jr. Thermochemical and Theoretical Studies of Dimethylpyridine-2,6-Dicarboxylate and PYRIDINE-2,3-, Pyridine-2,5-, and Pyridine-2,6-Dicarboxylic Acids. J. Chem. Eng. Data 2005, 50, 1184-1191. [CrossRef]

118. Roux, M.V.; Temprado, M.; Jimenez, P.; Foces-Foces, C.; Notario, R.; Verevkin, S.P.; Liebman, J.F. Thermochemistry of 2,5Thiophenedicarboxylic Acid. J. Phys. Chem. A 2006, 110, 12477-12483. [CrossRef] [PubMed]

119. Ribeiro da Silva, M.A.V.; Amaral, L.M.P.F.; Boaventura, C.R.P.; Gomes, J.R.B. Standard Molar Enthalpies of Formation of 2-, 3and 4-Cyanobenzoic Acids. J. Chem. Thermodyn. 2008, 40, 1226-1231. [CrossRef]

120. Ribeiro da Silva, M.A.V.; Santos, A.F.L.O.M. Thermochemical Properties of Three 2-Thiophenecarboxylic Acid Derivatives. J. Chem. Thermodyn. 2008, 40, 1451-1457. [CrossRef]

121. Temprado, M.; Roux, M.V.; Jimenez, P.; Foces-Foces, C.; Notario, R. Thermochemistry of 2- and 3-Thiopheneacetic Acids: Calorimetric and Computational Study. J. Phys. Chem. A 2008, 112, 10378-10385. [CrossRef]

122. Ribeiro da Silva, M.A.V.; Lobo Ferreira, A.I.M.C.; Lima, L.M.S.S.; Sousa, S.M.M. Thermochemistry of Phenylacetic and Monochlorophenylacetic acids. J. Chem. Thermodyn. 2008, 40, 137-145. [CrossRef]

123. Santos, R.C.; Figueira, R.M.B.B.M.; Piedade, M.F.M.; Diogo, H.M.; Minas da Piedade, M.E. Energetics and Structure of Hydroxynicotinic Acids. Crystal Structures of 2-, 4-, 6-Hydroxynicotinic and 5-Chloro-6-hydroxynicotinic Acids. J. Phys. Chem. B 2009, 113, 14291-14309. [CrossRef]

124. Ribeiro da Silva, M.A.V.; Lobo Ferreira, A.I.M.C.; Maciel, F.M. Experimental Standard Molar Enthalpies of Formation of Some 4-Alkoxybenzoic Acids. J. Chem. Thermodyn. 2010, 42, 220-224. [CrossRef]

125. Monte, M.J.S.; Goncalves, M.V.; Ribeiro da Silva, M.D.M.C. Vapor Pressures and Enthalpies of Combustion of the Dihydroxybenzoic Acid Isomers. J. Chem. Eng. Data 2010, 55, 2246-2251. [CrossRef]

126. Ribeiro da Silva, M.A.V.; Santos, A.F.L.O.M.; Carneiro, L.P.T.; Mendes, R.F.; Rodrigues, A.S.M.C.; Ferreira, P.J.O.; Ramos, R.M.C. Thermodynamic Study of 9-Anthracenecarboxylic Acid. J. Chem. Thermodyn. 2011, 43, 172-176. [CrossRef]

127. Amador, P.; Martínez, E.; Sánchez-Daza, O.; Flores, H. Energies of Combustion and Standard Molar Enthalpies of Formation of Ricinoleic Acid and Methyl Ricinoleate. J. Chem. Thermodyn. 2012, 50, 15-18. [CrossRef]

128. Levine, F.; Kayea, R.V., III; Wexler, R.; Sadvary, D.J.; Melick, C.; La Scala, J. Heats of Combustion of Fatty Acids and Fatty Acid Esters. J. Am. Oil Chem. Soc. 2014, 91, 235-249. [CrossRef]

129. Sobechko, I.B.; Van-Chin-Syan, Y.Y.; Kochubei, V.V.; Prokop, R.T.; Velychkivska, N.I.; Gorak, Y.I.; Dibrivnyi, V.N.; Obushak, M.D. Thermodynamic Properties of Furan-2-Carboxylic and 3-(2-Furyl)-2-Propenoic Acids. Russ. J. Phys. Chem. A 2014, 88, $2046-2053$. [CrossRef]

130. Miranda, M.S.; Duarte, D.J.R.; Liebman, D.J.F. What is the Enthalpy of Formation of Pyrazine-2-Carboxylic Acid? J. Chem. Thermodyn. 2016, 97, 261-263. [CrossRef]

131. Carvalho, T.M.T.; Amaral, L.M.P.F.; Morais, V.M.F.; Ribeiro da Silva, M.D.M.C. Energetic Effect of the Carboxylic Acid Functional Group in Indole Derivatives. J. Phys. Chem. A 2017, 121, 2980-2989. [CrossRef]

132. Emel'yanenko, V.N.; Turovtsev, V.V.; Fedina, Y.A.; Sikorski, P. Thermodynamic Properties of 2-Methyl Lactic Acid. J. Chem. Thermodyn. 2018, 127, 126-133. [CrossRef] 
133. Emel'yanenko, V.N.; Turovtsev, V.V.; Fedina, Y.A. Thermodynamic Properties of Pyruvic Acid and its Methyl Ester. Thermochim. Acta 2018, 665, 70-75. [CrossRef]

134. Dávalos, J.Z.; Lima, C.F.R.A.C.; Santos, L.M.N.B.F.; Romero, V.L.; Liebman, J.F. Thermochemical and Structural Studies of Gallic and Ellagic Acids. J. Chem. Thermodyn. 2019, 129, 108-113. [CrossRef]

135. Siewert, R.; Emel 'yanenko, V.N.; Verevkin, S.P. Thermochemistry of Phthalic Acids: Evaluation of Thermochemical Data with Complementary Experimental and Computational Methods. Fluid Phase Equil. 2020, 517, 112582. [CrossRef]

136. Mannson, M. Enthalpies of Combustion and Formation of Ethyl Propionate and Diethyl Carbonate. J. Chem. Thermodyn. 1972, 4, 865-871. [CrossRef]

137. Ribeiro da Silva, M.A.V.; Santos, L.M.N.B.F.; Schröder, B.; Dietze, F.; Beyer, L. Standard Molar Enthalpies of Formation of Three N-Benzoylthiocarbamic-O-Alkylesters. J. Chem. Thermodyn. 2004, 36, 491-495. [CrossRef]

138. Roux, M.V.; Temprado, M.; Notario, R.; Chickos, J.S.; Santos, A.F.L.O.M.; Ribeiro da Silva, M.A.V. Experimental and Computational Thermochemical Study of 2- and 3-Thiopheneacetic Acid Methyl Esters. J. Phys. Chem. A 2007, 111, 5280-5286. [CrossRef] [PubMed]

139. Verevkin, S.P.; Emelyanenko, V.N.; Toktonov, A.V.; Chernyak, Y.; Schäffner, B.; Börner, A. Cyclic Alkylene Carbonates. Experiment and First Principle Calculations for Prediction of Thermochemical Properties. J. Chem. Thermodyn. 2008, 40, 1428-1432. [CrossRef]

140. Amador, P.; Mata, M.Y.; Flores, H. Enthalpies of Combustion and Formation of $\alpha$-D-Glucoheptono- 1,4 -Lactone and $\alpha, \beta-$ Glucooctanoic-1,4-Lactone. J. Chem. Thermodyn. 2008, 40, 901-905. [CrossRef]

141. Verevkin, S.P.; Emel'yanenko, V.N.; Kozlova, S.A. Organic Carbonates: Experiment and Ab Initio Calculations for Prediction of Thermochemical Properties. J. Phys. Chem. A 2008, 112, 10667-10673. [CrossRef] [PubMed]

142. Ribeiro da Silva, M.A.V.; Santos, A.F.L.O.M. Calorimetric Study of Methyl and Ethyl 2-Thiophenecarboxylates and Ethyl 2- and 3-Thiopheneacetates. J. Chem. Thermodyn. 2009, 41, 926-931. [CrossRef]

143. Santos, A.F.L.O.M.; Ribeiro da Silva, M.A.V. Energetics and Molecular Structure of Alkyl 1-Methylpyrrolecarboxylates (alkyl = Methyl or Ethyl). J. Chem. Thermodyn. 2013, 67, 190-196. [CrossRef]

144. Santos, A.F.L.O.M.; Ribeiro da Silva, M.A.V. Experimental Redetermination of the Gas-Phase Enthalpy of Formation of Ethyl 2-Thiophenecarboxylate. J. Chem. Thermodyn. 2013, 58, 476-478. [CrossRef]

145. Carvalho, T.M.T.; Amaral, L.M.P.F.; Morais, V.M.F.; Ribeiro da Silva, M.D.M.C. Thermodynamic Properties of Alkyl 1H-Indole Carboxylate Derivatives: A Combined Experimental and Computational Study. J. Chem. Thermodyn. 2016, 97, 70-82. [CrossRef]

146. Xiao, G.; Xue, H.; Cheng, G.; Bao, X. Determination of Thermodynamic Parameters of Isopropyl Palmitate Synthesis. J. Chem. Eng. Chin. Univ. 2017, 31, 733-737. [CrossRef]

147. Sousa, C.; Matos, M.A.R.; Morais, V.M.F. Experimental and Computational Thermochemical Study of Maleic Anhydride and Vinylene Carbonate. J. Phys. Chem. A 2017, 121, 9474-9484. [CrossRef] [PubMed]

148. Ledo, J.M.; Flores, H.; Hernández-Pérez, J.M.; Ramos, F.; Camarillo, E.A.; Solano-Altamirano, J.M. Gas-Phase Enthalpies of Formation of Ethyl Hydroxybenzoates: An Experimental and Theoretical Approach. J. Chem. Thermodyn. 2018, 116, 176-184. [CrossRef]

149. Ledo, J.M.; Flores, H.; Solano-Altamirano, J.M.; Ramos, F.; Hernández-Pérez, J.M.; Camarillo, E.A.; Rabell, B.; Amador, M.P. Experimental and Theoretical Study of Methyl n-Hydroxybenzoates. J. Chem. Thermodyn. 2018, 124, 1-9. [CrossRef]

150. Verevkin, S.P.; Emel'yanenko, V.N.; Pimerzin, A.A.; Yermalayeu, A.V. How Much Different are Thermochemical Properties of Enantiomers and Their Racemates? Thermochemical Properties of Enantiopure and Racemate of Methyl- and Butyl Lactates. J. Chem. Phys. 2018, 149, 054506. [CrossRef]

151. Ledo, J.M.; Flores, H.; Freitas, V.L.S.; Solano-Altamirano, J.M.; Hernández-Pérez, J.M.; Ribeiro da Silva, M.D.M.C.; Camarillo, E.A. Thermal and Structural Properties of Ethyl 2- and 3-Aminobenzoates: Experimental and Computational Approaches. J. Chem. Thermodyn. 2019, 133, 93-99. [CrossRef]

152. Flores, H.; Ledo, J.M.; Camarillo, E.A.; Solano-Altamirano, J.M.; Hernández-Pérez, J.M.; Ramos, F.; Rabell, B. Thermochemical Study of Methyl N-Methoxybenzoates: An Experimental and Computational Approach. J. Chem. Eng. Data 2019, 64, 1898-1908. [CrossRef]

153. Ximello-Hernandez, A.; Freitas, V.L.S.; Ribeiro da Silva, M.D.M.C. Assessment of Thermochemical Data of $\gamma$-Butyrolactone from Experimental and Computational Studies. J. Chem. Eng. Data 2020, 65, 1968-1975. [CrossRef]

154. Freitas, V.L.S.; Silva, C.A.O.; Ribeiro da Silva, M.D.M.C. Thermochemical Study of Anthranilate Derivatives: Effect of the Size of the Alkyl Substituent. J. Chem. Thermodyn. 2021, 158, 106441. [CrossRef]

155. Pinto, S.S.; Diogo, H.P.; Moura-Ramos, J.J. Crystalline Anhydrous $\alpha, \alpha$-Trehalose (Polymorph $\beta$ ) and Crystalline Dihydrate $\alpha, \alpha$-Trehalose: A Calorimetric Study. J. Chem. Thermodyn. 2006, 38, 1130-1138. [CrossRef]

156. Swain, H.A., Jr.; Silbert, L.S.; Miller, J.G. The Heats of Combustion of Aliphatic Long Chain Peroxyacids, \& Butyl Peroxyesters, and Related Acids and Esters. J. Am. Chem. Soc. 1964, 86, 2562-2566. [CrossRef]

157. Romero, J.M.; Bustillo, S.; Maisuls, H.E.R.; Jorge, N.L.; Vara, M.E.G.; Castro, E.A.; Jubert, A.H. Calorimetric and Computational Study of Enthalpy of Formation of Diperoxide of Cyclohexanone. Int. J. Mol. Sci. 2007, 8, 688-694. [CrossRef]

158. Contini, A.E.; Bellamy, A.J.; Ahad, L.A. Taming the Beast: Measurement of the Enthalpies of Combustion and Formation of Triacetone Triperoxide (TATP) and Diacetone Diperoxide (DADP) by Oxygen Bomb Calorimetry. Propellants Explos. Pyrotech. 2012, 37, 320-328. [CrossRef] 
159. Van Chin Syan, Y.Y.; Pavlovskii, Y.P.; Gerasimchuk, S.I.; Dutka, V.S. The Standard Enthalpies of Formation and Thermal Stability of Diacyldiperoxides. Russ. J. Phys. Chem. A 2012, 86, 527-532. [CrossRef]

160. Pavlovskii, Y.P.; Kachurina, N.S.; Gerasimchuk, S.I.; Van Chin Syan, Y.Y. Thermochemical Properties of Tert Butyl and Cumyl Derivatives of Peroxide Compounds. Russ. J. Phys. Chem. A 2013, 87, 1253-1258. [CrossRef]

161. Sinditskii, V.P.; Kolesov, V.I.; Egorshev, V.Y.; Patrikeev, D.I.; Dorofeeva, O.V. Thermochemistry of Cyclic Acetone Peroxides. Thermochim. Acta 2014, 585, 10-15. [CrossRef]

162. Ribeiro da Silva, M.A.V.; Ribeiro da Silva, M.D.M.C.; Monteiro, M.F.B.M.; Gomes, M.L.A.C.N.; Chickos, J.S.; Smith, A.P.; Liebman, J.F. Thermochemical Studies for Determination of the Molar Enthalpy of Formation of Aniline Derivatives. Struct. Chem. 1996, 7, 367-373. [CrossRef]

163. Sabbah, R.; Perez, L. Energétique des Liaisons Inter- et Intramoléculaires Dans les Trois Isomères du Benzènediamine. Can. J. Chem. 1997, 75, 357-364. [CrossRef]

164. Verevkin, S.P.; Morgenthaler, J.; Rüchardt, C. Thermochemistry of Imines: Experimental Standard Molar Enthalpies of Formation. J. Chem. Thermodyn. 1997, 29, 1175-1183. [CrossRef]

165. Bazyleva, A.B.; Blokhin, A.V.; Kabo, A.G.; Kabo, G.J.; Emel'yanenko, V.N.; Verevkin, S.P. Thermodynamic Properties of 1-Aminoadamantane. J. Chem. Thermodyn. 2008, 40, 509-522. [CrossRef]

166. Ribeiro da Silva, M.A.V.; Lobo Ferreira, A.I.M.C.; Santos, A.F.L.O.M.; Ferreira, C.M.A.; Barros, D.C.B.; Reis, J.A.C.; Costa, J.C.S.; Calvinho, M.M.G.; Rocha, S.I.A.; Pinto, S.P.; et al. Enthalpies of Combustion, Vapour Pressures, and Enthalpies of Sublimation of the 1,5- and 1,8-Diaminonaphthalenes. J. Chem. Thermodyn. 2010, 42, 371-379. [CrossRef]

167. Ribeiro da Silva, M.A.V.; Santos, A.F.L.O.M. Diaminobenzenes: An Experimental and Computational Study. J. Phys. Chem. B 2011, 115, 4939-4948. [CrossRef]

168. Silva, A.I.R.; Gama, P.M.V.; Ribeiro da Silva, M.D.M.C. Influence of the Functional Groups $-\mathrm{NH}_{2},-\mathrm{OCH}_{3}$, and $-\mathrm{OH}$ on the Thermochemistry of Indanes. Can. J. Chem. 2019, 97, 788-794. [CrossRef]

169. Ledo, J.M.; Flores, H.; Freitas, V.L.S.; Solano-Altamirano, J.M.; Hernández-Pérez, J.M.; Camarillo, A.; Ramos, F.; Ribeiro da Silva, M.D.M.C. Benzocaine: A Comprehensive Thermochemical Study. J. Chem. Thermodyn. 2020, 147, 106119. [CrossRef]

170. Roux, M.V.; Jimenez, P.; Martin-Luengo, M.A.; Davalos, J.Z.; Sun, Z.; Hosmane, R.S.; Liebman, J.F. The Elusive Antiaromaticity of Maleimides and Maleic Anhydride: Enthalpies of Formation of N-Methylmaleimide, N-Methylsuccinimide, $N$ Methylphthalimide, and N-Benzoyl-N-methylbenzamide. J. Org. Chem. 1997, 62, 2732-2737. [CrossRef] [PubMed]

171. Ribeiro da Silva, M.D.M.C.; Goncalves, J.M.; Ferreira, S.C.C.; da Silva, L.C.M.; Sottomayor, M.J.; Pilcher, G.; Acree Jr., W. E.; Roy, L.E. Experimental Thermochemical Study of the Enthalpies of Formation and Sublimation of Isonicotinamide, Picolinamide, Nicotinamide, Isonicotinamide $\mathrm{N}$-Oxide, and Nicotinamide $\mathrm{N}$-Oxide. The Dissociation Enthalpies of the N-O Bonds. J. Chem. Thermodyn. 2001, 33, 1263-1275. [CrossRef]

172. Ribeiro da Silva, M.A.V.; Santos, L.M.N.B.F.; Schröder, B.; Beyer, L. Thermochemical Studies of Three N-Thiocarbamoylbenzamidines. J. Chem. Thermodyn. 2004, 36, 555-559. [CrossRef]

173. Ribeiro da Silva, M.A.V.; Cabral, J.I.T.A. Thermochemical Study of 1-, 3- and 4-Piperidinecarboxamide Derivatives. Thermochim. Acta 2007, 453, 147-151. [CrossRef]

174. Ribeiro da Silva, M.A.V.; Cabral, J.I.T.A. Experimental Study on the Thermochemistry of 1-(2H)-Phthalazinone and Phthalhydrazide. J. Chem. Thermodyn. 2008, 40, 829-835. [CrossRef]

175. Ribeiro da Silva, M.A.V.; Santos, A.F.L.O.M. Standard Molar Enthalpies of Formation and of Sublimation of 2-Thiophenecarboxamide and 2-Thiopheneacetamide. J. Chem. Thermodyn. 2008, 40, 166-173. [CrossRef]

176. Ribeiro da Silva, M.A.V.; Amaral, L.M.P.F.; Santos, A.F.L.O.M. Thermochemical and Thermophysical Study of 2-Thiophenecarboxylic acid Hydrazide and 2-Furancarboxylic Acid Hydrazide. J. Chem. Thermodyn. 2008, 40, 1588-1593. [CrossRef]

177. Almeida, A.R.R.P.; Matos, M.A.R.; Monte, M.J.S.; Morais, V.M.F. Experimental and Computational Thermodynamic Study of Ortho-, Meta-, and Para-Methylbenzamide. J. Chem. Thermodyn. 2012, 47, 81-89. [CrossRef]

178. Almeida, A.R.R.P.; Monte, M.J.S.; Matos, M.A.R.; Morais, V.M.F. Experimental and Computational Thermodynamic Study of Ortho- Meta- and Para-Aminobenzamide. J. Chem. Thermodyn. 2013, 59, 222-232. [CrossRef]

179. Almeida, A.R.R.P.; Monte, M.J.S.; Matos, M.A.R.; Morais, V.M.F. The Thermodynamic Stability of the Three Isomers of Methoxybenzamide: An Experimental and Computational Study. J. Chem. Thermodyn. 2014, 73, 12-22. [CrossRef]

180. Emel'yanenko, V.N.; Zaitseva, K.V.; Nagrimanov, R.N.; Solomonov, B.N.; Verevki, S.P. Benchmark Thermodynamic Properties of Methyl- and Methoxy-Benzamides: Comprehensive Experimental and Theoretical Study. J. Phys. Chem. A. 2016, 120, 42-8419. [CrossRef]

181. Ryskaliyeva, A.K.; Baltabayev, M.E.; Abaeva, K.T. Empirical Method for Predicting the Enthalpy Changes of Combustion of Amides. J. Serb. Chem. Soc. 2019, 84, 477-481. [CrossRef]

182. Ryskaliyeva, A.K.; Baltabayev, M.E.; Zhubatova, A.M. Thermochemical Properties and Regularities of Amides, Anilides, and Amidic Acids. Acta Chim. Slov. 2018, 65, 127-130. [CrossRef]

183. Verevkin, S.P.; Emel'yanenko, V.N.; Zaitsau, D.H. Thermochemistry of Substituted Benzamides and Substituted Benzoic Acids: Like Tree, Like Fruit? ChemPhysChem 2018, 19, 1-13. [CrossRef]

184. Ryskaliyeva, A.K.; Baltabayev, M.E.; Abaeva, K.T. Regularities of Enthalpies of Combustion of Nitrogen-Containing Organic Compounds. J. Chem. Soc. Pak. 2019, 41, 531-534. 
185. Freitas, V.L.S.; Ribeiro da Silva, M.D.M.C. Thermodynamic Properties of $\varepsilon$-Caprolactam and $\varepsilon$-Caprothiolactam. J. Chem. Thermodyn. 2019, 132, 451-460. [CrossRef]

186. Salas-Lopez, K.; García-Castro, M.A.; Amador, P.; Herrera-Gonzalez, A.M.; Galicia-Aguilar, A.; Amador, F.A.; Hernandez-Pascasio, F.; Flores, H. Standard Enthalpies of Formation of $N, N^{\prime}-(1,3-P h e n y l e n e) B i s(P h t h a l i m i d e)$ and $N, N^{\prime}-(1,3-P h e n y l e n e) B i s(P h t h a l i m i d e-$ 5-Carboxilic Acid). Thermochim. Acta 2021, 697, 178861. [CrossRef]

187. Perisanu, S.; Contineanu, I.; Neacsu, A.; Tanasescu, S. The Calorimetric Study of Some Guanidine Derivatives Involved in Living Bodies Nitrogen Metabolism. J. Therm. Anal. Calorim. 2010, 101, 1127-1133. [CrossRef]

188. Vitorino, J.; Agapito, F.; Piedade, M.F.M.; Bernardes, C.E.S.; Diogo, H.P.; Leal, J.P.; Minas da Piedade, M.E. Thermochemistry of 1,1,3,3-Tetramethylguanidine and 1,1,3,3-Tetramethylguanidinium Nitrate. J. Chem. Thermodyn. 2014, 77, 179-189. [CrossRef]

189. Huffman, H.M. Thermal Data. XI. The Heats of Combustion of Urea and Guanidine Carbonate and their Standard Free Energies of Formation. J. Am. Chem. Soc. 1940, 62, 1009-1011. [CrossRef]

190. Ribeiro da Silva, M.A.V.; Ribeiro da Silva, M.D.M.C.; Silva, L.C.M.; Dietze, F.; Hoyer, E. Thermochemical Study of Two N-Benzoyl$\mathrm{N}^{\prime}, \mathrm{N}^{\prime}$-Dialkylureas. J. Chem. Thermodyn. 2000, 32, 1113-1119. [CrossRef]

191. Ribeiro da Silva, M.A.V.; Ribeiro da Silva, M.D.M.C.; Silva, L.C.M.; Dietze, F.; Hoyer, E.; Beyer, L.; Schröder, B.; Damas, A.M.; Liebman, J.F. Synthesis, Characterization and Thermochemical Properties of N-Acyl- $\mathrm{N}^{\prime}, \mathrm{N}^{\prime}$-Diethylthioureas. J. Chem. Soc. Perkin Trans. 2001, 2, 2174-2178. [CrossRef]

192. Ribeiro da Silva, M.A.V.; Santos, L.M.N.B.F.; Schröder, B.; Beyer, L.; Dietze, F. Enthalpies of Combustion of Two Bis(N,NDiethylthioureas). J. Chem. Thermodyn. 2007, 39, 279-283. [CrossRef]

193. Ribeiro da Silva, M.D.M.C.; Ribeiro da Silva, M.A.V.; Freitas, V.L.S.; Roux, M.V.; Jimenez, P.; Temprado, M.; Davalos, J.Z.; Cabildo, P.; Claramunt, R.M.; Elguero, J. Structural Studies of Cyclic Ureas: 1. Enthalpies of Formation of Imidazolidin-2-One and N,N'-Trimethyleneurea. J. Chem. Thermodyn. 2008, 40, 386-393. [CrossRef]

194. Ribeiro da Silva, M.D.M.C.; Ribeiro da Silva, M.A.V.; Freitas, V.L.S.; Roux, M.V.; Jimenez, P.; Temprado, M.; Davalos, J.Z.; Cabildo, P.; Claramunt, R.M.; Elguero, J. Structural Studies of Cyclic Ureas: 3. Enthalpy of Formation of Barbital. J. Chem. Thermodyn. 2009, 41, 1400-1407. [CrossRef]

195. Silva, A.L.R.; Ribeiro da Silva, M.D.M.C. Comprehensive Thermochemical Study of Cyclic Five- and Six-Membered N,N'Thioureas. J. Chem. Eng. Data 2017, 62, 2584-2591. [CrossRef]

196. Verevkin, S.P.; Emelyanenko, V.N.; Zaitsau, D.H.; Surov, A.O.; Andrushko, V.; Pimerzin, A.A. Phenyl Substituted Ureas: Evaluation of Thermochemical Data with Complementary Experimental and Computational Methods. J. Chem. Thermodyn. 2019, 132, 439-450. [CrossRef]

197. Gantman, M.G.; Emel'yanenko, V.N.; Turovtsev, V.V.; Fedina, Y.A.; Verevkin, S.P. Thermodynamic Properties of Trimethylene Urethane (1,3-Oxazinan-2-One). J. Chem. Eng. Data 2018, 63, 4573-4579. [CrossRef]

198. Temprado, M.; Roux, M.V.; Parameswar, A.R.; Demchenko, A.V.; Chickos, J.S.; Liebman, J.F. Thermophysical Properties in Medium Temperature Range of Several Thio and Dithiocarbamates. J. Therm. Anal. Calorim. 2008, 91, 471-475. [CrossRef]

199. Dorofeeva, O.V.; Ryzhova, O.N.; Suntsova, M.A. Accurate Prediction of Enthalpies of Formation of Organic Azides by Combining G4 Theory Calculations with an Isodesmic Reaction Scheme. J. Phys. Chem. A 2013, 117, 6835-6845. [CrossRef]

200. Emelyanenko, V.N.; Algarra, M.; Esteves da Silva, J.C.C.; Hierrezuelo, J.; López-Romero, J.M.; Verevkin, S.P. Thermochemistry of Organic Azides Revisited. Thermochim. Acta 2014, 597, 78-84. [CrossRef]

201. Acree, W.E., Jr.; Tucker, S.A.; Zvaigzne, A.I.; Meng-Yan, Y.; Pilcher, G.; Ribeiro da Silva, M.D.M.C. Enthalpies of Combustion of 2,4,6-Trimethylbenzonitrile, 2,4,6-Trimethylbenzonitrile $N$-Oxide, 2,6-Dimethylbenzonitrile, 2,4,6-Trimethoxybenzonitrile, and 2,4,6-Trimethoxybenzonitrile N-Oxide: The Dissociation Enthalpies of the (N-O) Bonds. J. Chem. Thermodyn. 1991, 23, 31-36. [CrossRef]

202. Acree, W.E., Jr.; Tucker, S.A.; Pilcher, G. Enthalpies of Combustion of 1,4-Dicyanobenzene Di-N-Oxide and 1,4-Dicyanobenzene: The Mean Dissociation Enthalpy of the (N-O) Bonds. J. Chem. Thermodyn. 1992, 24, 213-216. [CrossRef]

203. Ribeiro da Silva, M.A.V.; Lobo Ferreira, A.I.M.C.; Barros, A.L.M.; Bessa, A.R.C.; Brito, B.C.S.A.; Vieira, J.A.S.; Martins, S.A.P. Standard Molar Enthalpies of Formation of 1- and 2-Cyanonaphthalene. J. Chem. Thermodyn. 2011, 43, 1306-1314. [CrossRef]

204. Perisanu, S.; Contineanu, I.; Neacsu, A.; Notario, R.; Roux, M.V.; Liebman, J.F.; Dodson, B.J. Thermochemistry and Quantum Chemical Calculationsof Two Dibenzocycloalkane Nitriles. Struct. Chem. 2011, 22, 89-94. [CrossRef]

205. Ribeiro da Silva, M.A.V.; Monte, M.J.S.; Rocha, I.M.; Cimas, A. Energetic Study Applied to the Knowledge of the Structural and Electronic Properties of Monofluorobenzonitriles. J. Org. Chem. 2012, 77, 4312-4322. [CrossRef]

206. Rocha, I.M.; Galvao, T.L.P.; Ribeiro da Silva, M.D.M.C.; Ribeiro da Silva, M.A.V. Energetic Study of Bromobenzonitrile Isomers: Insights on the Intermolecular Interactions, Aromaticity and Electronegativity. Struct. Chem. 2013, 24, 1935-1944. [CrossRef]

207. Rocha, I.M.; Ribeiro da Silva, M.D.M.C.; Ribeiro da Silva, M.A.V. Thermodynamic and Aromaticity Studies for the Assessment of the Halogen Cyano Interactions on Iodobenzonitrile. J. Chem. Thermodyn. 2013, 65, 204-212. [CrossRef]

208. Rocha, I.M.; Galvao, T.L.P.; Ribeiro da Silva, M.D.M.C.; Ribeiro da Silva, M.A.V. Thermodynamic Study of Chlorobenzonitrile Isomers: A Survey on the Polymorphism, Pseudosymmetry, and the Chloro Cyano Interaction. J. Phys. Chem. A 2014, 118, 1502-1510. [CrossRef] [PubMed]

209. Smirnova, N.N.; Kandeev, K.V.; Bykova, T.A.; Kulagina, T.G. Thermodynamics of 1,4-Diisocyanatobutane in the Range from T $\rightarrow$ (0 to 360) K at Standard Pressure. J. Chem. Thermodyn. 2006, 38, 376-382. [CrossRef] 
210. Li, H.-Y.; Yan, B.; Guan, Y.-L.; Ma, H.-X.; Song, J.-R.; Zhao, F.-Q. Thermodynamic Properties of 4-Amino-3-Furazanecarboxamidoxime. J. Chem. Thermodyn. 2015, 90, 87-91. [CrossRef]

211. Miroshnichenko, E.A.; Kon'kova, T.S.; Matyushin, Y.N.; Inozemtsev, Y.O. Bond Dissociation Energies in Nitramines. Russ. Chem. Bull. 2009, 58, 2015-2019. [CrossRef]

212. Byström, K. Enthalpies of Combustion, Vaporization, and Formation for Di- $N$-Propyldiazene $N$-Oxide and Di-T-Butyldiazene N-Oxide. J. Chem. Thermodyn. 1981, 13, 139-145. [CrossRef]

213. Dias, A.R.; Minas de Piedade, M.E.; Martinho Simoes, J.A.; Simoni, J.A.; Teixeira, C.; Diogo, H.P.; Meng-Yan, Y.; Pilcher, G. Enthalpies of Formation of cis-Azobenzene and Trans-Azobenzene. J. Chem. Thermodyn. 1992, 24, 439-447. [CrossRef]

214. Kirpichev, E.P.; Zyuzin, I.N.; Avdonin, V.V.; Rubtsov, Y.I.; Lempert, D.B. The Standard Enthalpies of Formation of Alkoxy-NNOAzoxy Compounds. Russ. J. Phys. Chem. 2006, 80, 1359-1362. [CrossRef]

215. Kirchner, J.J.; Acree, W.E., Jr.; Pilcher, G.; Shaofeng, L. Enthalpies of Combustion of Four N-Phenylmethylene Benzenamine $\mathrm{N}$-Oxide Derivatives, of $\mathrm{N}$-Phenylmethylene Benzenamine, and of Trans-Diphenyldiazene $N$-Oxide: The Dissociation Enthalpy of the (N-O) Bonds. J. Chem. Thermodyn. 1986, 18, 793-799. [CrossRef]

216. Acree, W.E., Jr.; Kirchner, J.J.; Tucker, S.A.; Pilcher, G.; Ribeiro da Silva, M.D.M.C. Enthalpies of Combustion of Three Benzylidene t-Butylamine $\mathrm{N}$-Oxide Derivatives and of 4-Nitrobenzylidene t-Butylamine: The Dissociation Enthalpies of the (N-O) Bonds. J. Chem. Thermodyn. 1989, 21, 443-448. [CrossRef]

217. Acree, W.E., Jr.; Tucker, S.A.; Ribeiro da Silva, M.D.M.C.; Matos, M.A.R.; Ribeiro da Silva, M.A.V.; Pilcher, G. Enthalpies of Combustion of 3-Nitropyridine N-Oxide and Pyridine-3-Carboxylic Acid N-Oxide: The Dissociation Enthalpies of the N-O Bonds in Pyridine N-Oxide Derivatives. J. Chem. Thermodyn. 1995, 27, 391-398. [CrossRef]

218. Acree, W.E., Jr.; Powell, J.R.; Tucker, S.A.; Ribeiro da Silva, M.D.M.C.; Matos, M.A.R.; Goncalves, J.M.; Santos, L.M.N.B.F.; Morais, V.M.F.; Pilcher, G. Thermochemical and Theoretical Study of Some Quinoxaline 1,4-Dioxides and of Pyrazine 1,4-Dioxide. J. Org. Chem. 1997, 62, 3722-3726. [CrossRef]

219. Ribeiro da Silva, M.D.M.C.; Matos, M.A.R.; Vaz, M.C.; Santos, L.M.N.B.F.; Pilcher, G.; Acree, W.E., Jr.; Powell, J.R. Enthalpies of Combustion of the Pyridine N-Oxide Derivatives: 4-Methyl-, 3-Cyano-, 4-Cyano-, 3-Hydroxy-, 2-Carboxy-, 4-Carboxy-, and 3-Methyl-4-Nitro, and of the Pyridine Derivatives: 2-Carboxy-, and 4-Carboxy-. The Dissociation Enthalpies of the N-O Bonds. J. Chem. Thermodyn. 1998, 30, 869-878. [CrossRef]

220. Ribeiro da Silva, M.D.M.C.; Santos, L.M.N.B.F.; Silva, A.L.R.; Fernandes, O.; Acree, W.E., Jr. Energetics of 6-Methoxyquinoline and 6-Methoxyquinoline N-Oxide: The Dissociation Enthalpy of the (N-O) Bond. J. Chem. Thermodyn. 2003, 35, 1093-1100. [CrossRef]

221. Ribeiro da Silva, M.D.M.C.; Gomes, J.R.B.; Goncalves, J.M.; Sousa, E.A.; Pandey, S.; Acree, W.E., Jr. Thermodynamic Properties of Quinoxaline-1,4-Dioxide Derivatives: A Combined Experimental and Computational Study. J. Org. Chem. 2004, 69, $2785-2792$. [CrossRef] [PubMed]

222. Ribeiro da Silva, M.D.M.C.; Gomes, J.R.B.; Goncalves, J.M.; Sousa, E.A.; Pandey, S.; Acree, W.E., Jr. Thermochemistry of 2-Amino3-Quinoxalinecarbonitrile-1,4-Dioxide. Evaluation of the Mean Dissociation Enthalpy of the (N-O) Bond. Org. Biomol. Chem. 2004, 2, 2507-2512. [CrossRef] [PubMed]

223. Gomes, J.R.B.; Sousa, E.A.; Goncalves, J.M.; Monte, M.J.S.; Gomes, P.; Pandey, S.; Acree, W.E., Jr.; Ribeiro da Silva, M.D.M.C. Energetics of the N-O Bonds in 2-Hydroxyphenazine-Di-N-Oxide. J. Phys. Chem. B 2005, 109, 16188-16195. [CrossRef]

224. Acree, W.E., Jr.; Pilcher, G.; Ribeiro da Silva, M.D.M.C. The Dissociation Enthalpies of Terminal (N-O) Bonds in Organic Compounds. J. Phys. Chem. Ref. Data 2005, 34, 553-572. [CrossRef]

225. Ribeiro da Silva, M.D.M.C.; Vieira, M.A.A.; Givens, C.; Keown, S.; Acree, W.E., Jr. Experimental Thermochemical Study of Two Polymethylpyrazine $N, N^{\prime}$-Dioxide Derivatives. Thermochim. Acta 2006, 450, 67-70. [CrossRef]

226. Gomes, J.R.B.; Sousa, E.A.; Gomes, P.; Vale, N.; Goncalves, J.M.; Pandey, S.; Acree, W.E., Jr.; Ribeiro da Silva, M.D.M.C. Thermochemical Studies on 3-Methyl-Quinoxaline-2-Carboxamide-1,4-Dioxide Derivatives: Enthalpies of Formation and of N-O Bond Dissociation. J. Phys. Chem. B 2007, 111, 2075-2080. [CrossRef] [PubMed]

227. Cabral, J.I.T.A.; Monteiro, R.A.R.; Rocha, M.A.A.; Santos, L.M.N.B.F.; Acree, W.E., Jr.; Ribeiro da Silva, M.D.M.C. Molecular Energetics of Alkyl Substituted Pyridine N-Oxides. J. Therm. Anal. Calorim. 2010, 100, 431-439. [CrossRef]

228. Gomes, J.R.B.; Monteiro, A.R.; Campos, B.B.; Gomes, P.; Ribeiro da Silva, M.D.M.C. The Enthalpies of Dissociation of the N-O Bonds in Two Quinoxaline Derivatives. J. Phys. Org. Chem. 2009, 22, 17-23. [CrossRef]

229. Viveiros, M.L.F.; Freitas, V.L.S.; Vale, N.; Gomes, J.R.B.; Gomes, P.; Ribeiro da Silva, M.D.M.C. Synthesis and Thermochemical Study of Quinoxaline-N-Oxides: Enthalpies of Dissociation of the N-O Bond. J. Phys. Org. Chem. 2012, 25, 420-426. [CrossRef]

230. Santos, A.F.L.O.M.; Monteiro, A.R.; Goncalves, J.M.; Acree, W.E., Jr.; Ribeiro da Silva, M.D.M.C. Thermochemistry of 2,2'-Dipyridil N-Oxide and 2,2'-Dipyridil N,N'-Dioxide. The Dissociation Enthalpies of the N-O Bonds. J. Chem. Thermodyn. 2011, 43, $1044-1049$. [CrossRef]

231. Ribeiro da Silva, M.D.M.C.; Ferreira, S.C.C.; Rodrigues, I.A.P.; da Silva, L.C.M.; Acree, W.E., Jr.; Pandey, S.; Roy, L.E. Experimental Standard Molar Enthalpies of Formation of Crystalline 3,5-Dimethylpyrazole, 3,5-Dimethyl-4-Nitrosopyrazole, 1,3,5-Trimethyl-4Nitrosopyrazole, and 3,5-Dimethyl-1-Phenyl-4-Nitrosopyrazole. J. Chem. Thermodyn. 2001, 33, 1227-1235. [CrossRef]

232. Young, J.A.; Keith, J.E.; Stehle, P.; Dzombak, W.C.; Hunt, H. Heats of Combustion of Some Organic Nitrogen Compounds. Ind. Eng. Chem. 1956, 48, 1375-1378. [CrossRef]

233. Verevkin, S.P. Thermochemistry of Nitro Compounds. Experimental Standard Enthalpies of Formation and Improved GroupAdditivity Values. Thermochim. Acta 1997, 307, 17-25. [CrossRef] 
234. Ribeiro da Silva, M.A.V.; Matos, M.A.R.; Monte, M.J.S.; Hillesheim, D.M.; Marques, M.C.P.O.; Vieira, N.F.T.G. Enthalpies of Combustion, Vapour Pressures, and Enthalpies of Sublimation of Three Methoxy-Nitrobenzoic Acids. Vapour Pressures and Enthalpies of Sublimation of the Three Nitrobenzoic Acids. J. Chem. Thermodyn. 1999, 31, 1429-1441. [CrossRef]

235. Ribeiro da Silva, M.A.V.; Lima, L.M.S.S.; Amaral, L.M.P.F.; Ferreira, A.I.M.C.L.; Gomes, J.R.B. Standard Molar Enthalpies of Formation, Vapour Pressures, and Enthalpies of Sublimation of 2-Chloro-4-Nitroaniline and 2-Chloro-5-Nitroaniline. J. Chem. Thermodyn. 2003, 35, 1343-1359. [CrossRef]

236. Miranda, M.S.; Morais, V.M.F.; Matos, M.A.R. Standard Molar Enthalpies of Formation of the Methoxynitrophenol Isomers: A Combined Experimental and Theoretical Investigation. J. Chem. Thermodyn. 2004, 36, 431-436. [CrossRef]

237. Feng-Qi, Z.; Pei, C.; Rong-Zu, H.; Yang, L.; Zhi-Zhong, Z.; Yan-Shui, Z.; Xu-Wu, Y.; Yin, G.; Sheng-Li, G.; Qi-Zhen, S. Thermochemical Properties and Non-Isothermal Decomposition Reaction Kinetics of 3,4-Dinitrofurazanfuroxan (DNTF). J. Hazard. Mat. A 2004, 113, 67-71. [CrossRef]

238. Ribeiro da Silva, M.A.V.; Amaral, L.M.P.F.; Santos, A.F.L.O.M.; Gomes, J.R.B. Thermochemistry of Nitronaphthalenes and Nitroanthracenes. J. Chem. Thermodyn. 2006, 38, 748-755. [CrossRef]

239. Ribeiro da Silva, M.A.V.; Lima, L.M.S.S.; Moreno, A.R.G.; Ferreira, A.I.M.C.L.; Gomes, J.R.B. Combined Experimental and Computational Thermochemistry of Isomers of Chloronitroanilines. J. Chem. Thermodyn. 2008, 40, 155-165. [CrossRef]

240. Ribeiro da Silva, M.A.V.; Ferreira, A.I.M.C.L.; Moreno, A.R.G. Experimental and Computational Thermochemical Study of the Dichloronitrobenzene Isomers. J. Chem. Thermodyn. 2009, 41, 904-910. [CrossRef]

241. Ribeiro da Silva, M.A.V.; Cabral, J.I.T.A. Experimental Study on the Thermochemistry of 5-Nitroindole and 5-Nitroindoline. J. Chem. Thermodyn. 2009, 41, 355-360. [CrossRef]

242. Mel'khanova, S.V.; Pimenova, S.M.; Yashin, N.V. The Standard Enthalpies of Formation of 1-Nitrodispiro[2.0.2.1]Heptane and 1-Nitrodispiro[2.0.3.1]Octane. Russ. J. Phys. Chem. A 2009, 83, 1241-1243. [CrossRef]

243. Ribeiro da Silva, M.A.V.; Santos, A.F.L.O.M. Thermochemical Properties of two Nitrothiophene Derivatives. 2-Acetyl-5Nitrothiophene and 5-Nitro-2-Thiophenecarboxaldehyde. J. Therm. Anal. Calorim. 2010, 100, 403-411. [CrossRef]

244. Ribeiro da Silva, M.A.V.; Amaral, L.M.P.F.; Ortiz, R.V. Experimental Study on the Thermochemistry of 3-Nitrobenzophenone, 4-Nitrobenzophenone and 3,30-Dinitrobenzophenone. J. Chem. Thermodyn. 2011, 43, 546-551. [CrossRef]

245. Ribeiro da Silva, M.A.V.; Amaral, L.M.P.F. Standard Molar Enthalpies of Formation of $3^{\prime}$ - and $4^{\prime}$-Nitroacetophenones. J. Chem. Thermodyn. 2011, 43, 876-881. [CrossRef]

246. Ferreira, A.I.M.C.L.; Ribeiro da Silva, M.A.V. Experimental and Computational Study of the Thermochemistry of the Three Iodonitrobenzene Isomers. J. Chem. Thermodyn. 2013, 59, 94-106. [CrossRef]

247. Verevkin, S.P.; Emel'yanenko, V.N.; Diky, V.; Dorofeeva, O.V. Enthalpies of Formation of Nitromethane and Nitrobenzene: New Experiments vs. Quantum Chemical Calculations. J. Chem. Thermodyn. 2014, 73, 163-170. [CrossRef]

248. Oliveira, J.A.S.A.; Monte, M.J.S.; Notario, R.; Ribeiro da Silva, M.D.M.C. Experimental and Computational Study of the Thermodynamic Properties of 2-Nitrofluorene and 2-Aminofluorene. J. Chem. Thermodyn. 2014, 76, 56-63. [CrossRef]

249. García-Castro, M.A.; Amador, P.; Hernandez-Perez, J.M.; Medina-Favela, A.E.; Flores, H. Experimental and Computational Thermochemistry of 3- and 4-Nitrophthalic Anhydride. J. Phys. Chem. A 2014, 118, 3820-3826. [CrossRef] [PubMed]

250. Sun, Q.; Zhang, Y.; Xu, K.; Ren, Z.; Song, J.; Zhao, F. Studies on Thermodynamic Properties of FOX-7 and Its Five Closed-Loop Derivatives. J. Chem. Eng. Data 2015, 60, 2057-2061. [CrossRef]

251. Klapötke, T.M.; Witkowski, T.G. 5,5'-Bis(2,4,6-Trinitrophenyl)-2,2'-Bi(1,3,4-Oxadiazole) (TKX-55): Thermally Stable Explosive with Outstanding Properties. ChemPlusChem 2016, 81, 357-360. [CrossRef]

252. Kazakov, A.I.; Dalinger, I.L.; Zyuzin, I.N.; Lempert, D.B.; Plishkin, N.A.; Sheremetev, A.B. Enthalpies of Formation of 3,4- and 3,5-Dinitro-1-Trimethyl-1H-Pyrazoles. Russ. Chem. Bull. 2016, 65, 2783-2788. [CrossRef]

253. Carvalho, T.M.T.; Amaral, L.M.P.F.; Morais, V.M.F.; Ribeiro da Silva, M.D.M.C. Calorimetric and Computational Studies for Three Nitroimidazole Isomers. J. Chem. Thermodyn. 2017, 105, 267-275. [CrossRef]

254. Bikelyte, G.; Härtel, M.; Stierstorfer, J.; Klapötke, T.M.; Pimerzin, A.A.; Verevkin, S.P. Benchmark Properties of 2-, 3- and 4-Nitrotoluene: Evaluation of Thermochemical Data with Complementary Experimental and Computational Methods. J. Chem. Thermodyn. 2017, 111, 271-278. [CrossRef]

255. Salas-Lopez, K.; Amador, P.; Rojas, A.; Melendez, F.J.; Flores, H. Experimental and Theoretical Thermochemistry of the Isomers 3and 4-Nitrophthalimide. J. Phys. Chem. A 2017, 121, 5509-5519. [CrossRef]

256. Zhang, J.-Q.; Liu, R.; Ji, T.-Z.; Ren, J.-C.; Guo, Q.; Wang, B.-Z.; Hu, R.-Z. Thermal Behavior and Thermal Safety of 6bNitrohexahydro-2H-1,3,5-Trioxacyclopenta[cd]-Pentalene-2,4,6-Triyltrinitrate. RSC Adv. 2017, 7, 30747-30754. [CrossRef]

257. Gutowski, L.; Trzcinski, W.; Szala, M. 5,5',6,6'-Tetranitro-2,2'-Bibenzimidazole: A Thermally Stable and Insensitive Energetic Compound. ChemPlusChem 2018, 83, 87-91. [CrossRef] [PubMed]

258. García-Castro, M.A.; Amador, P.; Rojas, A.; Hernández-Pérez, J.M.; Solano-Altamirano, J.M.; Flores, H.; Salas-López, K. Experimental and Computational Thermochemistry of 3- and 4-Nitrophthalic Acids. J. Chem. Thermodyn. 2018, 127, 117-125. [CrossRef]

259. Pimenova, S.M.; Lukyanova, V.A.; Ilin, D.Y.; Druzhinina, A.I.; Dorofeeva, O.V. Standard Enthalpies of Formation of Dicyclopropyldinitromethane and Tricyclopropylmethane. J. Chem. Thermodyn. 2019, 132, 316-321. [CrossRef]

260. Sun, Q.; Li, Y.-f.; Xu, K.-Z.; Song, J.-R.; Zhao, F.-Q. Crystal Structure and Enthalpy of Combustion of AEFOX-7. Chin. J. Energ. Mater. 2015, 23, 1235-1239. 
261. Gutowski, L.; Gołofit, T.; Trzciński, W.; Szala, M. Synthesis and Energetic Properties of 1,3,7,9-Tetranitrobenzo[c]Cinnoline-5-Oxide (TNBCO). Propellants Explos. Pyrotech. 2019, 44, 1-7. [CrossRef]

262. Lukyanov, O.A.; Parakhin, V.V.; Shlykova, N.I.; Dmitrienko, A.O.; Melnikova, E.K.; Konkova, T.S.; Monogarov, K.A.; Meerov, D.B. Energetic N-Azidomethyl Derivatives of Polynitro Hexaazaisowurtzitanes Series: The Most Highly Enthalpy Analogues of CL-20. New J. Chem. 2020, 44, 8357-8365. [CrossRef]

263. Jia, Q.; Zhang, J.; Zhang, S.; Shi, Q.; Lei, D.; Xu, Y.; Kou, K. Low-Temperature Heat Capacities, Standard Molar Enthalpies of Formation and Detonation Performance of Two CL-20 Cocrystal Energetic Materials. Fluid Phase Equil. 2020, $518,112638$. [CrossRef]

264. Burcat, A. Thermodynamic Properties of Ideal Gas Nitro and Nitrate Compounds. J. Phys. Chem. Ref. Data 1999, 28, 63-130. [CrossRef]

265. Contineanu, I.; Neacsu, A.; Perisanu, S. The Standard Enthalpies of Formation of L-Asparagine and L-a-Glutamine. Thermochim. Acta 2010, 497, 96-100. [CrossRef]

266. Gridchin, S.N.; Volkov, A.V.; Dmitrieva, N.G.; Romodanovskii, P.A. Enthalpies of the Formation and Dissolution of D Asparagine Monohydrate in Water and Aqueous Solutions of Potassium Hydroxide. Russ. J. Phys. Chem. A 2011, 85, 2038-2040. [CrossRef]

267. Roux, M.V.R.; Notario, R.; Segura, M.; Chickos, J.S.; Liebman, J.F. The Enthalpy of Formation of Methionine Revisited. J. Phys. Org. Chem. 2012, 25. [CrossRef]

268. Santos, A.F.L.O.M.; Amaral, L.M.P.F.; Ribeiro da Silva, M.D.M.C.; Roux, M.V.R.; Notario, R. Experimental and Computational Study on the Energetics of the Cyclic Anhydrides of Glycine and Alanine. J. Chem. Thermodyn. 2013, 58, 29-35. [CrossRef]

269. Ovchinnikov, V.V. Thermochemistry of Heteroatomic Compounds: Analysis and Calculation of Thermodynamic Functions of Amino Acids and Some Peptides of Different Space Structure. Am. J. Phys. Chem. 2013, 2, 8-15. [CrossRef]

270. Amaral, L.M.P.F.; Santos, A.F.L.O.M.; Ribeiro da Silva, M.D.M.C.; Notario, R. Thermochemistry of Sarcosine and Sarcosine Anhydride: Theoretical and Experimental Studies. J. Chem. Thermodyn. 2013, 58, 315-321. [CrossRef]

271. Notario, R.; Roux, M.V.R.; Santos, A.F.L.O.M.; Ribeiro da Silva, M.D.M.C. Experimental and Computational Study on the Energetics of N-Acetyl-L-Cysteine. J. Chem. Thermodyn. 2014, 73, 57-61. [CrossRef]

272. Gheorghe, D.; Neacsu, A.; Contineanu, I.; Teodorescu, F.; Tanasescu, S. Thermochemical Properties of L-Alanine Nitrate and L-Alanine Ethyl Ester Nitrate. J. Therm. Anal. Calorim. 2014, 118, 731-737. [CrossRef]

273. Emel'yanenko, V.N.; Zaitsau, D.H.; Shoifet, E.; Meurer, F.; Verevkin, S.P.; Schick, C.; Held, C. Benchmark Thermochemistry for Biologically Relevant Adenine and Cytosine. A Combined Experimental and Theoretical Study. J. Phys. Chem. A 2015, 119, 9680-9691. [CrossRef] [PubMed]

274. Lukyanova, V.A.; Druzhinina, A.I.; Pimenova, S.M.; Ioutsi, V.A.; Buyanovskaya, A.G.; Takazova, R.U.; Sagadeyev, E.V.; Gimadeev, A.A. Thermodynamic Properties of L-Tryptophan. J. Chem. Thermodyn. 2017, 105, 44-49. [CrossRef]

275. Lukyanova, V.A.; Druzhinina, A.I.; Pimenova, S.M.; Ioutsi, V.A.; Buyanovskaya, A.G.; Takazova, R.U.; Sagadeyev, E.V.; Gimadeev, A.A. Thermodynamic Properties of L-Threonine. J. Chem. Thermodyn. 2018, 116, 248-252. [CrossRef]

276. Neacsu, A.; Gheorghe, D.; Contineanu, I.; Sofronia, A.M.; Teodorescu, F.; Perisanu, S. Enthalpies of Combustion and Formation of Histidine Stereoisomers. J. Chem. 2018, 2018, 7801381. [CrossRef]

277. Knyazev, A.V.; Emel'yanenko, V.N.; Shipilova, A.S.; Zaitsau, D.H.; Smirnova, N.N.; Knyazeva, S.S.; Gulenova, M.V. Thermodynamic Investigation of L-Carnitine. J. Chem. Thermodyn. 2019, 131, 495-502. [CrossRef]

278. Mackle, H.; O'Hare, P.A.G. The Thermochemistry of Sulfur-Containing Molecules and Radicals-I. Heats of Combustion and Formation. Tetrahedron 1963, 19, 961-971. [CrossRef]

279. Mackle, H.; Steele, W.V. Studies in the Thermochemistry of Organic Sulphites and Sulphates. Part 1. Heats of Combustion and Formation of Some Dialkyl Sulphites and Sulphates. Trans. Faraday Soc. 1969, 65, 2053-2059. [CrossRef]

280. Good, W.D. Enthalpies of Combustion of 18 Organic Sulfur Compounds Related to Petroleum. J. Chem. Eng. Data 1972, 17, 158-162. [CrossRef]

281. Meng-Yan, Y.; Pilcher, G.; Macnab, J.I. Standard Enthalpies of Formation in the Crystalline State of Aminomethanesulfonic Acid, 2-Aminoethanesulfonic Acid, and the Three Aminobenzenesulfonic Acids. J. Chem. Thermodyn. 1994, 26, 787-790. [CrossRef]

282. Davalos, J.Z.; Flores, H.; Jimenez, P.; Notario, R.; Roux, M.V.; Juaristi, E.; Hosmane, R.S.; Liebman, J.F. Calorimetric, Computational (G2(MP2) and G3) and Conceptual Study of the Energetics of the Isomeric 1,3- and 1,4-Dithianes. J. Org. Chem. 1999, 64, $9328-9336$. [CrossRef]

283. Roux, M.V.; Davalos, J.Z.; Jimenez, P.; Flores, H.; Saiz, J.-L.; Abboud, J.-L.M.; Juaristi, E. Structural Effects on the Thermochemical Properties of Sulfur Compounds: I. Enthalpy of Combustion, Vapour Pressures, Enthalpy of Sublimation, and Standard Molar Enthalpy of Formation in the Gaseous Phase of 1,3-Dithiane. J. Chem. Thermodyn. 1999, 31, 635-646. [CrossRef]

284. Roux, M.V.; Temprado, M.; Jimenez, P.; Davalos, J.Z.; Notario, R.; Martin-Valcarcel, G.; Garrido, L.; Guzman-Mejia, J.E. Thermochemistry of 1,3-Dithiacyclohexane 1-Oxide (1,3-Dithiane Sulfoxide): Calorimetric and Computational Study. J. Org. Chem. 2004, 69, 5454-5459. [CrossRef]

285. Masuda, N.; Nagano, Y.; Kimura, T. Standard Molar Enthalpy of Formation of $\mathrm{CH}_{3}\left(\mathrm{CH}_{3} \mathrm{SCH}_{2}\right) \mathrm{SO}$, Methyl Methylthiomethyl Sulfoxide. J. Therm. Anal. Calorim. 2005, 81, 533-535. [CrossRef]

286. Camarillo, E.A.; Flores, H. Determination of the Energies of Combustion and Enthalpies of Formation of Nitrobenzenesulfonamides by Rotating-Bomb Combustion Calorimetry. J. Chem. Thermodyn. 2010, 42, 425-428. [CrossRef] 
287. Flores, H.; Camarillo, E.A.; Amador, P. Enthalpies of Combustion and Formation of Benzenesulfonamide and Some of its Derivatives. J. Chem. Thermodyn. 2012, 47, 408-411. [CrossRef]

288. Ramos, F.; Flores, H.; Hernandez-Perez, J.M.; Sandoval-Lira, J.; Camarillo, E.A. The Intramolecular Hydrogen Bond N-H S in 2,2'-Diaminodiphenyl Disulfide, Experimental and Computational Thermochemistry. J. Phys. Chem. A 2018, 122, 239-248. [CrossRef] [PubMed]

289. Kirklin, D.R.; Chickos, J.S.; Liebman, J.F. Enthalpy of Formation of Triphenylphosphine Sulfide. Struct. Chem. 1996, 7, 355-361. [CrossRef]

290. Lebedev, B.V.; Kulagina, T.G. Thermodynamics of Hexachlorocyclotriphosphazene and Octachlorocyclotetraphosphazene from $\mathrm{T} \rightarrow 0$ to $\mathrm{T}=450 \mathrm{~K}$. J. Chem. Thermodyn. 1999, 31, 697-710. [CrossRef]

291. Tannenbaum, S.; Kaye, S.; Lewenz, G.F. Synthesis and Properties of Some Alkylsilanes. J. Am. Chem. Soc. 1953, 75, 3753-3757. [CrossRef]

292. Good, W.D.; Lacina, J.L.; DePrater, B.L.; McCullough, J.P. A New Approach to the Combustion Calorimetry of Silicon and Organosilicon Compounds. Heats of Formation of Quartz, Fluorosilicic Acid, and Hexamethyldisiloxane. J. Phys. Chem. 1964, 68, 579-586. [CrossRef]

293. Dibrivnyi, V.N.; Melnik, G.V.; Van-Chin-Syan, Y.Y.; Yuvchenko, A.P. The Thermodynamic Properties of Four Triphenylsilane Acetylene Peroxides. Russ. J. Phys. Chem. 2006, 80, 330-334. [CrossRef]

294. Dibrivnyi, V.N.; Pavlovskii, Y.P.; Van-Chin-Syan, Y.Y. Formation Enthalpies of Peroxy-Substituted Silanes. Russ. J. Phys. Chem. A 2010, 84, 778-783. [CrossRef]

295. Johnson, W.H.; Kilday, M.V.; Prosen, E.J. Heats of Combustion and Formation of Trimethylborane, Triethylborane, and Tri- $n-$ butylborane. J. Res. Nat. Bur. Stand.-A Phys. Chem. 1961, 65, 215-219. [CrossRef]

296. Smith, L. Corrected Heats of Combustion of Organic Iodine Compounds. Acta Chem. Scand. 1956, 10, 884-886. [CrossRef]

297. Bjellerup, L. On the Accuracy of Heat of Combustion Data Obtained with Precision Moving-Bomb Calorimetric Method for Organic Bromine Compounds. Acta Chem. Scand. 1961, 15, 121-140. [CrossRef]

298. Good, W.D.; Douslin, D.R.; McCullough, J.P. 1,2-Difluoroamino-4-methylpentane: Heats of Combustion, Formation, and Vaporization; Vapor Pressure; and N-F Thermochemical Bond Energy. J. Phys. Chem. 1963, 67, 1312-1314. [CrossRef]

299. Cox, J.D.; Gundry, H.A.; Head, A.J. Thermodynamic Properties of Fluorine Compounds. Part 1-Heats of Combustion of p-Fluorobenzoic acid, Pentafluorobenzoic Acid, Hexafluorobenzene and Decafluorocyclohexene. Trans. Faraday Soc. 1964, 60, 653-665. [CrossRef]

300. Smith, N.K.; Gorin, G.; Good, W.D.; McCullough, J.P. The Heats of Combustion, Sublimation, and Formation of Four Dihalobiphenyls. J. Phys. Chem. 1964, 68, 940-946. [CrossRef]

301. Good, W.D.; Smith, N.K. Enthalpies of Combustion and Formation of 1,1-Bis(Difluoroamino)Heptane. N-F Thermochemical Bond Energy. J. Chem. Eng. Data 1970, 15, 147-150. [CrossRef]

302. Price, S.J.W.; Sapiano, H.J. Determination of $\Delta \mathrm{H}_{\mathrm{f} 298}{ }^{0}\left(\mathrm{C}_{12} \mathrm{~F}_{10, \mathrm{~g}}\right)$ from Studies of the Combustion of Decafluorobiphenyl in Oxygen and Calculation of $\mathrm{D}\left(\mathrm{C}_{6} \mathrm{~F}_{5}-\mathrm{C}_{6} \mathrm{~F}_{5}\right)$. Can. J. Chem. 1979, 57, 1468-1470. [CrossRef]

303. Shaub, W.M. Procedure for Estimating the Heats of Formation of Aromatic Compounds: Chlorinated Benzenes, Phenols and Dioxins. Thermochim. Acta 1982, 55, 59-73. [CrossRef]

304. Zhogina, E.V.; Papina, T.S.; Kolesov, V.P.; Kosareva, L.N.; Ivanova, T.Y. Enthalpy of Formation of Perfluoro-2,7-Dimethyloctane. Thermochim. Acta 1989, 139, 43-47. [CrossRef]

305. Ribeiro da Silva, M.A.V.; Ferrao, M.L.C.C.H.; Lopes, A.J.M. Enthalpies of Combustion of Each of the Two Bromonaphthalenes. J. Chem. Thermodyn. 1993, 25, 229-235. [CrossRef]

306. Ribeiro da Silva, M.A.V.; Ferrao, M.L.C.C.H.; Jiye, F. Standard Enthalpies of Combustion of the Six Dichlorophenols by RotatingBomb Calorimetry. J. Chem. Thermodyn. 1994, 26, 839-846. [CrossRef]

307. Carson, A.S.; Laye, P.G.; Pedley, J.B.; Welsby, A.M.; Chickos, J.S.; Hosseini, S. The Enthalpy of Formation of Odoethane, 1,2-Diiodoethane, 1,3-Diiodopropane, and 1.4-Diiodobutane. J. Chem. Thermodyn. 1994, 26, 1103-1109. [CrossRef]

308. Sabbah, R.; Aguilar, A.R. Etude Thermodynamique des Trois Isomeres de L'acide Chlorobenzoique. Partie II. Can. J. Chem. 1995, 73, 1538-1545. [CrossRef]

309. Xu-Wu, A.; Da-Jun, G. Formation Enthalpies and Non-Bonding Interactions of Hexachlorocyclohexanes. Thermochim. Acta 1995, $253,235-242$.

310. Ribeiro da Silva, M.A.V.; Matos, M.A.R.; Amaral, L.M.P.F. Standard Molar Enthalpies of Formation of 2- and 3-Bromopyridine and of 2,5- and 2,6-Dibromopyridine. J. Chem. Thermodyn. 1997, 29, 1545-1551. [CrossRef]

311. Ribeiro da Silva, M.A.V.; Goncalves, J.M.; Pilcher, G. Standard Molar Enthalpies of Formation of Nine Fluorinated $\beta$-Diketones by Rotating Bomb Calorimetry. J. Chem. Thermodyn. 1997, 29, 253-260. [CrossRef]

312. Ribeiro da Silva, M.A.V.; Matos, M.A.R.; Amaral, L.M.P.F. Standard Molar Enthalpies of Formation of Some Chloropyridines. J. Chem. Thermodyn. 1997, 29, 1535-1543. [CrossRef]

313. Papina, T.S.; Kolesov, V.P.; Lukyanova, V.A.; Boltalina, O.V.; Galeva, N.A.; Sidorov, L.N. The Standard Molar Enthalpy of Formation of Fluorofullerene $\mathrm{C}_{60} \mathrm{~F}_{48}$. J. Chem. Thermodyn. 1999, 31, 1321-1328. [CrossRef]

314. Ribeiro da Silva, M.A.V.; Amaral, L.M.P.F.; Ferreira, A.I.M.C.L. Standard Molar Enthalpies of Formation of Some Trichloroanilines by Rotating-Bomb Calorimetry. J. Chem. Thermodyn. 2002, 34, 119-127. [CrossRef] 
315. Morais, V.M.F.; Miranda, M.S.; Matos, M.A.R. Thermochemical Study of Chloropyrazines and Chloroquinoxalines. J. Chem. Thermodyn. 2004, 36, 377-383. [CrossRef]

316. Ribeiro da Silva, M.A.V.; Gomes, J.R.B.; Ferreira, A.I.M.C.L. Experimental and Computational Investigation of the Energetics of the Three Isomers of Monochloroaniline. J. Phys. Chem. B 2005, 109, 13356-13362. [CrossRef]

317. Gomes, J.R.B.; Amaral, L.M.P.F.; Ribeiro da Silva, M.A.V. Gas-Phase Thermochemistry of Chloropyridines. Chem. Phys. Lett. 2005, 406, 154-160. [CrossRef]

318. Ribeiro da Silva, M.A.V.; Amaral, L.M.P.F.; Gomes, J.R.B. Experimental and Computational Investigation of the Thermochemistry of the Six Isomers of Dichloroaniline. J. Phys. Chem. A 2006, 110, 9301-9306. [CrossRef]

319. Ribeiro da Silva, M.A.V.; Ferreira, A.I.M.C.L.; Gomes, J.R.B. Experimental and Computational Study on the Thermochemistry of Bromoanilines. Bull. Chem. Soc. Jpn. 2006, 79, 1852-1859. [CrossRef]

320. Ribeiro da Silva, M.A.V.; Ferreira, A.I.M.C.L.; Gomes, J.R.B. Experimental and Computational Study on the Thermochemistry of the Isomers of Iodoaniline and Diiodoaniline. Chem. Phys. Lett. 2006, 422, 565-570. [CrossRef]

321. Ribeiro da Silva, M.A.V.; Matos, M.A.R.; Amaral, L.M.P.F. Standard Molar Enthalpies of Formation of 2-Chloroquinoline, 4Chloroquinoline, 6-Chloroquinoline and 4,7-Dichloroquinoline by Rotating-Bomb calorimetry. J. Chem. Thermodyn. 2006, 38, 49-55. [CrossRef]

322. Ribeiro da Silva, M.A.V.; Ferreira, A.I.M.C.L.; Gomes, J.R.B. Combined Experimental and Computational Study of the Thermochemistry of the Fluoroaniline Isomers. J. Phys. Chem. B 2007, 111, 2052-2061. [CrossRef] [PubMed]

323. Ribeiro da Silva, M.A.V.; Amaral, L.M.P.F.; Gomes, J.R.B. Comparative Computational and Experimental Study on the Thermochemistry of the Chloropyrimidines. J. Phys. Chem. B 2007, 111, 792-799. [CrossRef]

324. Ribeiro da Silva, M.A.V.; Amaral, L.M.P.F. Gas Phase Enthalpy of Formation of 3-Bromoquinoline. J. Therm. Anal. Calorim. 2008, 92, 53-57. [CrossRef]

325. Ribeiro da Silva, M.A.V.; Ferreira, A.I.M.C.L. Standard Molar Enthalpies of Formation of the Three Isomers of Chloroanisole. J. Chem. Thermodyn. 2008, 40, 362-368. [CrossRef]

326. Ribeiro da Silva, M.A.V.; Ferreira, A.I.M.C.L. Thermochemical Study of Four Isomers of Dichloroanisole. J. Chem. Thermodyn. 2008, 40, 924-930. [CrossRef]

327. Ribeiro da Silva, M.A.V.; Ferreira, A.I.M.C.L. Experimental and Computational Thermochemical Study of the Three Monofluorophenol Isomers. J. Chem. Eng. Data 2009, 54, 2517-2526. [CrossRef]

328. Ribeiro da Silva, M.A.V.; Cabral, J.I.T.A. Experimental Thermochemical Study of 5-Bromoindole and 5-Bromoindoline. J. Chem. Thermodyn. 2009, 41, 84-89. [CrossRef]

329. Ribeiro da Silva, M.A.V.; Ferreira, A.I.M.C.L.; Moreno, A.R.G. Experimental Thermochemical Study of the Monochloronitrobenzene Isomers. J. Chem. Thermodyn. 2009, 41, 109-114. [CrossRef]

330. Ribeiro da Silva, M.A.V.; Ferreira, A.I.M.C.L. Experimental and computational study on the molecular energetics of the three monofluoroanisole isomers. J. Chem. Thermodyn. 2009, 41, 361-366. [CrossRef]

331. Ribeiro da Silva, M.A.V.; Ferreira, A.I.M.C.L. Experimental and Computational Study on the Molecular Energetics of Monobromoanisole Isomers. J. Chem. Thermodyn. 2009, 41, 499-505. [CrossRef]

332. Ribeiro da Silva, M.A.V.; Ferreira, A.I.M.C.L.; Cabral, J.I.T.A.; Santos, A.F.L.O.M.; Moreno, A.R.G.; Galvão, T.L.P.; Rocha, I.M.; Fernandes, P.M.V.; Salgueiro, S.Q.; de Moura, V.A.F.; et al. Experimental and Computational Thermochemical Study of the Tri-, Tetra-, and Pentachloronitrobenzene Isomers. J. Chem. Thermodyn. 2009, 41, 984-991. [CrossRef]

333. Ribeiro da Silva, M.A.V.; Ribeiro da Silva, M.D.M.C.; Ferreira, A.I.M.C.L.; Santos, A.F.L.O.M.; Galvão, T.L.P. Experimental Thermochemical Study of 2,5- and 2,6-Dichloro-4-Nitroanilines. J. Chem. Thermodyn. 2009, 41, 1074-1080. [CrossRef]

334. Ribeiro da Silva, M.A.V.; Ferreira, A.I.M.C.L. Gas Phase Enthalpies of Formation of Monobromophenols. J. Chem. Thermodyn. 2009, 41, 1104-1110. [CrossRef]

335. Ribeiro da Silva, M.A.V.; Ferreira, A.I.M.C.L.; Santos, A.F.L.O.M.; Rocha, I.M. Thermochemical Study of the 2,5-Dibromonitrobenzene Isomer: An Approach of the Energetic Study for the Other Dibromonitrobenzene Isomers. J. Chem. Thermodyn. 2009, 41, 1239-1246. [CrossRef]

336. Ribeiro da Silva, M.A.V.; Ribeiro da Silva, M.D.M.C.; Ferreira, A.I.M.C.L.; Santos, A.F.L.O.M.; Galvão, T.L.P. Experimental Thermochemical Study of 4,5-Dichloro-2-Nitroaniline. J. Chem. Thermodyn. 2009, 41, 1247-1253. [CrossRef]

337. Ribeiro da Silva, M.A.V.; Monte, M.J.S.; Ferreira, A.I.M.C.L.; Oliveira, J.A.S.A.; Cimas, A. Experimental and Computational Thermodynamic Study of Three Monofluoronitrobenzene Isomers. J. Phys. Chem. B 2010, 114, 7909-7919. [CrossRef] [PubMed]

338. Ribeiro da Silva, M.A.V.; Monte, M.J.S.; Ferreira, A.I.M.C.L.; Oliveira, J.A.S.A.; Cimas, A. A Combined Experimental and Computational Thermodynamic Study of Difluoronitrobenzene Isomers. J. Phys. Chem. B 2010, 114, 12914-12925. [CrossRef] [PubMed]

339. Ribeiro da Silva, M.A.V.; Ferreira, A.I.M.C.L.; Santos, A.F.L.O.M.; Rocha, I.M. Thermochemical Study of the Monobromonitrobenzene Isomers. J. Chem. Thermodyn. 2010, 42, 169-176. [CrossRef]

340. Ribeiro da Silva, M.A.V.; Ferreira, A.I.M.C.L. Calorimetric and computational thermochemical study of difluorophenol isomers. J. Chem. Thermodyn. 2010, 42, 182-188. [CrossRef]

341. Ribeiro da Silva, M.A.V.; Ribeiro da Silva, M.D.M.C.; Santos, A.F.L.O.M.; Ferreira, A.I.M.C.L.; Galvao, T.L.P. Experimental Thermochemical Study of two Chlorodinitroaniline Isomers. J. Chem. Thermodyn. 2010, 42, 496-501. [CrossRef] 
342. Ribeiro da Silva, M.D.M.C.; Ribeiro da Silva, M.A.V.; Freitas, V.L.S.; Roux, M.V.; Jimenez, P.; Davalos, J.Z.; Cabildo, P.; Claramunt, R.M.; Pinilla, E.; Torres, M.R.; et al. Energetic Studies of Urea Derivatives: Standard Molar Enthalpy of Formation of 3,4,40Trichlorocarbanilide. J. Chem. Thermodyn. 2010, 42, 536-544. [CrossRef]

343. Santos, A.F.L.O.M.; Ribeiro da Silva, M.A.V. Experimental and Computational Energetic Study of Two Halogenated 2Acetylpyrrole Derivatives: 2-Trichloroacetylpyrrole and 2-Trifluoroacetylpyrrole. J. Chem. Thermodyn. 2010, 42, 1079-1086. [CrossRef]

344. Santos, A.F.L.O.M.; Ribeiro da Silva, M.A.V. A Calorimetric and Computational Study of the Thermochemistry of Halogenated 1-Phenylpyrrole Derivatives. J. Chem. Thermodyn. 2010, 42, 1441-1450. [CrossRef]

345. Ribeiro da Silva, M.A.V.; Amaral, L.M.P.F. Standard Molar Enthalpies of Formation of Monochloroacetophenone Isomers. J. Chem. Thermodyn. 2010, 42, 1473-1477. [CrossRef]

346. Ferreira, A.I.M.C.L.; Ribeiro da Silva, M.A.V. Experimental and Computational Thermochemical Study of the Three Monoiodophenol Isomers. J. Chem. Eng. Data 2011, 56, 4881-4890. [CrossRef]

347. Ferreira, A.I.M.C.; Ribeiro da Silva, M.A.V. Thermochemical Study of Three Dibromophenol Isomers. J. Chem. Thermodyn. 2011, 43, 227-234. [CrossRef]

348. Ribeiro da Silva, M.A.V.; Amaral, L.M.P.F. Thermochemical Study of Some Dichloroacetophenone Isomers. J. Chem. Thermodyn. 2011, 43, 255-261. [CrossRef]

349. Ferreira, A.I.M.C.; Ribeiro da Silva, M.A.V. Experimental and Computational Study of the Molecular Energetics of the Monoiodoanisole Isomers. J. Chem. Thermodyn. 2012, 48, 84-92. [CrossRef]

350. Ribeiro da Silva, M.A.V.; Amaral, L.M.P.F.; Szterner, P. Experimental Thermochemical Study of Fluoro-, Chloro-, and Bromoderivatives of Uracil. J. Chem. Thermodyn. 2012, 52, 30-35. [CrossRef]

351. Lukyanova, V.A.; Papina, T.S. Standard Enthalpies of Formation of Perfluoro(2-Methyl-3-Oxa)Hexanoic and Perfluoro(2,5Dimethyl-3,6-Dioxa)Nonanoic Acids. Russ. J. Phys. Chem. A 2013, 87, 340-341. [CrossRef]

352. Miranda, M.S.; Matos, M.A.R.; Morais, V.M.F. Structure and Energetics Correlations in Some Chlorohydroxypyridines. J. Chem. Thermodyn. 2013, 62, 170-177. [CrossRef]

353. Amaral, L.M.P.F.; Ribeiro da Silva, M.A.V. Experimental Thermochemical Study of 2-Chloroacetophenone and 2,4'Dichloroacetophenone. J. Chem. Thermodyn. 2014, 73, 44-50. [CrossRef]

354. Amaral, L.M.P.F.; Ribeiro da Silva, M.A.V. Calorimetric Study of Bromoacetophenone Isomers. J. Chem. Thermodyn. 2014, 78, 254-259. [CrossRef]

355. Oliveira, J.A.S.A.; Santos, A.F.L.O.M.; Ribeiro da Silva, M.D.M.C.; Monte, M.J.S. Thermodynamic Properties of Bromine Fluorene Derivatives: An Experimental and Computational Study. J. Chem. Thermodyn. 2015, 89, 134-141. [CrossRef]

356. Szterner, P.; Amaral, L.M.P.F.; Morais, V.M.F.; Ribeiro da Silva, M.D.M.C.; Ribeiro da Silva, M.A.V. Thermochemical Study of Dichloromethylpyrimidine Isomers. J. Chem. Thermodyn. 2016, 100, 148-155. [CrossRef]

357. Purnell, D.L., Jr.; Bozzelli, J.W. Thermochemical Properties: Enthalpy, Entropy, and Heat Capacity of C2-C3 Fluorinated Aldehydes. Radicals and Fluorocarbon Group Additivity. J. Phys. Chem. A 2019, 123, 650-665. [CrossRef] [PubMed]

358. Beak, P.; White, J.M. Relative Enthalpies of 1,3-Dimethy1-2,4-Pyrimidinedione, 2,4-Dimethoxypyrimidine, and 4-Methoxy-1Methyl-2-Pyrimidinone: Estimation of the Relative Stabilities of Two Protomers of Uracil. J. Am. Chem. Soc. 1982, 104, 7073-7077. [CrossRef]

359. Kirklin, D.R.; Domalski, E.S. Enthalpy of Combustion of Purine. J. Chem. Thermodyn. 1984, 16, 633-641. [CrossRef]

360. Johnson, W.H.; Prosen, E.J. Determination of the Enthalpies of Combustion and Formation of Substituted Triazines in an Adiabatic Rotating Bomb Calorimeter. J. Res. Nat. Bur. Stand. 1985, 90, 295-303. [CrossRef]

361. Wu, D.; Xu, G.; Qu, S.; Xue, R.; Gu, C.; Zhang, F. Standard Enthalpies of Combustion and Formation of Porphyrin Derivatives. Thermochim. Acta 1989, 154, 233-245. [CrossRef]

362. Ciocazanu, I.; Meltzer, V.; Nicolae, A.; Vilcu, R. Etude Thermodynamique de Quelques Dérivés Sustitués de 1'Acide 1-PhenazineCarboxylique. Calorim. Anal. Therm. 1997, 28, 267-272.

363. Verevkin, S.P. Thermochemistry of Amines: Experimental Standard Molar Enthalpies of Formation of N-Alkylated Piperidines. Struct. Chem. 1998, 9, 113-119. [CrossRef]

364. Ribeiro da Silva, M.A.V.; Ribeiro da Silva, M.D.M.C.; Matos, M.A.R.; Jimenez, P.; Roux, M.V.; Elguero, J.; Claramunt, R.; Cabildo, P.; Sanchez-Migallon, A. Enthalpies of Combustion, Heat Capacities, and Enthalpies of Vaporization of 1-Ethylimidazole and 1-Ethylpyrazole. J. Chem. Thermodyn. 1999, 31, 129-138. [CrossRef]

365. Chirico, R.D.; Knipmeyer, S.E.; Nguyen, A.; Steele, W.V. Thermodynamic Properties of the Methylpyridines. Part 2. Vapor pressures, Heat Capacities, Critical Properties, Derived Thermodynamic Functions between the Temperatures $250 \mathrm{~K}$ and $560 \mathrm{~K}$, and Equilibrium Isomer Distributions for All Temperatures $\geq 250$ K. J. Chem. Thermodyn. 1999, 31, 339-378. [CrossRef]

366. Patino, R.; Torres, L.A.; Campos, M. The Standard Molar Enthalpies of Formation of 5,10,15,20-Tetraphenylporphine and 5,10,15,20-Tetrakis(4-Methoxyphenyl)Porphine by Oxygen Bomb Combustion Calorimetry. J. Chem. Thermodyn. 1999, 31, 627-634. [CrossRef]

367. Mo, O.; Yanez, M.; Roux, M.V.; Jimenez, P.; Davalos, J.Z.; Ribeiro da Silva, M.A.V.; Ribeiro da Silva, M.D.M.C.; Matos, M.A.R.; Amaral, L.M.P.F.; Sanchez-Migallon, A.; et al. Enthalpies of Formation of N-Substituted Pyrazoles and Imidazoles. J. Phys. Chem. A 1999, 103, 9336-9344. [CrossRef] 
368. Ribeiro da Silva, M.A.V.; Ribeiro da Silva, M.D.M.C.; Matos, M.A.R.; Jimenez, P.; Roux, M.V.; Martin-Luengo, M.A.; Elguero, J.; Claramunt, R.; Cabildo, P. Enthalpies of Combustion, Heat Capacities, and Enthalpies of Vaporisation of 1-Phenylimidazole and 1-Phenylpyrazole. J. Chem. Thermodyn. 2000, 32, 237-245. [CrossRef]

369. Verevkin, S.P. Relationships among Strain Energies of Mono- and Poly-Cyclic Cyclohexanoid Molecules and Strain of Their Component Rings. J. Chem. Thermodyn. 2002, 34, 263-275. [CrossRef]

370. Qing, W.; Xuwu, Y.; Shengli, G.; Qizhen, S. Preparation and the Standard Enthalpy of Formation of 2-Amino-4,6Dimethoxypyrimidine and the Related Complexes of Copper. Chem. Pap. 2003, 57, 97-101.

371. Chirico, R.D.; Knipmeyer, S.E.; Steele, W.V. Heat Capacities, Enthalpy Increments, and Derived Thermodynamic Functions for Pyrazine between the Temperatures 5K and 380K. J. Chem. Thermodyn. 2003, 35, 1059-1072. [CrossRef]

372. Ribeiro da Silva, M.A.V.; Ribeiro da Silva, M.D.M.C.; Amaral, L.M.P.F.; Jimenez, P.; Roux, M.V.; Davalos, J.Z.; Temprado, M.; Cabildo, P.; Claramunt, R.; Elguero, J.; et al. Experimental Thermochemical Study of Two 2-Alkylbenzimidazole Isomers (Alkyl = Propyl and Isopropyl). J. Chem. Thermodyn. 2004, 36, 533-539. [CrossRef]

373. Ribeiro da Silva, M.A.V.; Cabral, J.I.T.A.; Gomes, P.; Gomes, J.R.B. Combined Experimental and Computational Study of the Thermochemistry of Methylpiperidines. J. Org. Chem. 2006, 71, 3677-3685. [CrossRef] [PubMed]

374. Ribeiro da Silva, M.D.M.C.; Miranda, M.S.; Vaz, C.M.V.; Matos, M.A.R.; Acree, W.E., Jr. Experimental Thermochemical Study of Three Monosubstituted Pyrazines. J. Chem. Thermodyn. 2005, 37, 49-53. [CrossRef]

375. Ribeiro da Silva, M.A.V.; Ribeiro da Silva, M.D.M.C.; Amaral, L.M.P.F.; Elguero, J.; Jimenez, P.; Roux, M.V.; Davalos, J.Z.; Temprado, M.; Cabildo, P.; Claramunt, R.; et al. Thermochemical Properties of Two Benzimidazole Derivatives: 2-Phenyl- and 2-Benzylbenzimidazole. J. Chem. Thermodyn. 2005, 37, 1168-1176. [CrossRef]

376. Ribeiro da Silva, M.A.V.; Matos, M.A.R.; Amaral, L.M.P.F. Thermochemical Studies of 1-Hydroxyisoquinoline, 5-Hydroxyisoquinoline and 1,5-Dihydroxyisoquinoline. J. Chem. Thermodyn. 2005, 37, 1312-1317. [CrossRef]

377. Chirico, R.D.; Steele, W.V. Thermodynamic Properties of 2-Methylquinoline and 8-Methylquinoline. J. Chem. Eng. Data 2005, 50, 697-708. [CrossRef]

378. Morais, V.M.F.; Miranda, M.S.; Matos, M.A.R. Experimental and Computational Thermochemistry of the Dihydroxypyridine Isomers. J. Chem. Thermodyn. 2006, 38, 450-454. [CrossRef]

379. Miranda, M.S.; Morais, V.M.F.; Matos, M.A.R. Thermochemical Study of Cyanopyrazines: Experimental and Theoretical Approaches. J. Chem. Thermodyn. 2006, 38, 559-564. [CrossRef]

380. Ribeiro da Silva, M.A.V.; Cabral, J.I.T.A. Standard Molar Enthalpies of Formation of 2-, 3-, and 4-Piperidinomethanol Isomers. J. Chem. Thermodyn. 2006, 38, 1008-1012. [CrossRef]

381. Ribeiro da Silva, M.A.V.; Cabral, J.I.T.A.; Gomes, J.R.B. Experimental and Computational Study on the Thermochemistry of Ethylpiperidines. J. Chem. Thermodyn. 2006, 38, 1072-1078. [CrossRef]

382. Ribeiro da Silva, M.A.V.; Cabral, J.I.T.A. Thermochemistry of Some Derivatives of 2- and 4-Piperidone. J. Chem. Eng. Data 2006, 51, 1556-1561. [CrossRef]

383. Freitas, V.L.S.; Oliveira, L.I.P.; Ribeiro da Silva, M.D.M.C. Standard Molar Enthalpies of Formation of the Acetylpyridine Isomers. J. Chem. Thermodyn. 2007, 39, 39-43. [CrossRef]

384. Ribeiro da Silva, M.A.V.; Cabral, J.I.T.A. Thermochemical Proerties of Three Piperidine Derivatives. 1-Benzyl-4-Piperidinol, 4-Benzylpiperidine and 4-Piperidine-Piperidine. J. Therm. Anal. Calorim. 2007, 90, 865-871. [CrossRef]

385. Ribeiro da Silva, M.A.V.; Cabral, J.I.T.A. Standard Molar Enthalpy of Formation of 1-Cyano-acetylpyridine. J. Therm. Anal. Calorim. 2008, 92, 59-62. [CrossRef]

386. Ribeiro da Silva, M.D.M.C.; Cabral, J.I.T.A.; Givens, C.; Keown, S.; Acree, W.E., Jr. Thermochemical Study of Three Dimethylpyrazine Derivatives. J. Therm. Anal. Calorim. 2008, 92, 73-78. [CrossRef]

387. Ribeiro da Silva, M.A.V.; Figueiredo, D.F.; Cabral, J.I.T.A. Thermochemical Studies of 3-Methylpyrazole and 1,3,5Trimethylpyrazole. J. Chem. Thermodyn. 2008, 40, 369-374. [CrossRef]

388. Rocha, M.A.A.; Gomes, L.R.; Low, J.N.; Santos, L.M.N.B.F. Energetic and Structural Study of Diphenylpyridine Isomers. J. Phys. Chem. A 2009, 113, 11015-11027. [CrossRef]

389. Santos, A.F.L.O.M.; Ribeiro da Silva, M.A.V. Experimental and Computational Thermochemistry of 1-Phenylpyrrole and 1-(4Methylphenyl)Pyrrole. J. Chem. Thermodyn. 2010, 42, 734-741. [CrossRef]

390. Miranda, M.S.; Matos, M.A.R.; Morais, V.M.F.; Liebman, J.F. Experimental and Computational Thermochemical Study of Oxindole. J. Chem. Thermodyn. 2010, 42, 1101-1106. [CrossRef]

391. Ribeiro da Silva, M.A.V.; Cabral, J.I.T.A.; Cimas, A. Experimental and Computational Study of the Energetics of 5- and 6Aminoindazole. J. Chem. Thermodyn. 2010, 42, 1240-1247. [CrossRef]

392. Santos, A.F.L.O.M.; Ribeiro da Silva, M.A.V. Energetics of 1-(Aminophenyl)Pyrroles: A Joint Calorimetric and Computational Study. J. Chem. Thermodyn. 2011, 43, 1480-1487. [CrossRef]

393. Ribeiro da Silva, M.A.V.; Amaral, L.M.P.F.; Szterner, P. Experimental Study on the Thermochemistry of Some Amino Derivatives of Uracil. J. Chem. Thermodyn. 2011, 43, 1763-1767. [CrossRef]

394. Ribeiro da Silva, M.A.V.; Amaral, L.M.P.F.; Szterner, P. Thermochemical Study of 5-Methyluracil, 6-Methyluracil, and 5-Nitrouracil. J. Chem. Thermodyn. 2011, 43, 1924-1927. [CrossRef]

395. Lima, C.F.R.A.C.; Costa, J.C.S.; Santos, L.M.N.B.F. Thermodynamic Insights on the Structure and Energetics of s-Triphenyltriazine. J. Phys. Chem. A 2011, 115, 9249-9258. [CrossRef] [PubMed] 
396. Ribeiro da Silva, M.A.V.; Cabral, J.I.T.A. Standard Molar Enthalpies of Formation of Three Methyl-Pyrazole Derivatives. J. Chem. Thermodyn. 2012, 47, 138-143. [CrossRef]

397. Amaral, L.M.P.F.; Ribeiro da Silva, M.A.V. Thermochemistry of Some Methoxypyridines. J. Chem. Thermodyn. 2012, 48, 65-69. [CrossRef]

398. Ribeiro da Silva, M.A.V.; Galvão, T.L.P.; Rocha, I.M.; Santos, A.F.L.O.M. Aromaticity and Stability Going in Opposite Directions: An Energetic, Structural, Magnetic and Electronic Study of Aminopyrimidines. J. Chem. Thermodyn. 2012, 54, 330-338. [CrossRef]

399. Roux, M.V.; Notario, R.; Zaitsau, D.H.; Emel'yanenko, V.N.; Verevkin, S.P. Experimental and Computational Thermochemical Study of 2-Thiobarbituric Acid: Structure-Energy Relationship. J. Phys. Chem. A 2012, 116, 4639-4645. [CrossRef] [PubMed]

400. Notario, R.; Emel'yanenko, V.N.; Roux, M.V.; Ros, F.; Verevkin, S.P.; Chickos, J.S.; Liebman, J.F. Thermochemistry of Uracils. Experimental and Computational Enthalpies of Formation of 5,6-Dimethyl-, 1,3,5-Trimethyl-, and 1,3,5,6-Tetramethyluracils. J. Phys. Chem. A 2013, 117, 244-251. [CrossRef]

401. Ribeiro da Silva, M.A.V.; Amaral, L.M.P.F.; Szterner, P. Experimental Study on the Thermochemistry of 2-Thiouracil, 5-Methyl-2Thiouracil and 6-Methyl-2-Thiouracil. J. Chem. Thermodyn. 2013, 57, 380-386. [CrossRef]

402. Silva, A.L.R.; Cimas, A.; Vale, N.; Gomes, P.; Monte, M.J.S.; Ribeiro da Silva, M.D.M.C. Experimental and Computational Study of the Energetics of Hydantoin and 2-Thiohydantoin. J. Chem. Thermodyn. 2013, 58, 158-165. [CrossRef]

403. Galvão, T.L.P.; Ribeiro da Silva, M.D.M.C.; Ribeiro da Silva, M.A.V. Energetics of Aminomethylpyrimidines: An Examination of the Aromaticity of Nitrogen Heteromonocyclic Derivatives. J. Chem. Thermodyn. 2013, 62, 186-195. [CrossRef]

404. Blokhin, A.V.; Kohut, S.V.; Kabo, G.J.; Stepurko, E.N.; Paulechka, Y.U.; Voitkevich, O.V. Thermodynamic Properties of 1-Ethyl-4Nitro-1,2,3-Triazole. Thermochim. Acta 2013, 565, 221-226. [CrossRef]

405. Notario, R.; Roux, M.V.; Ros, F.; Emel'yanenko, V.N.; Verevkin, S.P. Experimental and Computational Thermochemical Study of 1,3,5-Trimethyl-, 1,5,5-Trimethyl-, and 1,3,5,5-Tetramethyl-Barbituric Acids. J. Chem. Thermodyn. 2014, 74, 144-152. [CrossRef]

406. Amaral, L.M.P.F.; Szterner, P.; Miranda, M.S.; Ribeiro da Silva, M.A.V. Enthalpy of Formation of 5-Fluoro-1,3-Dimethyluracil: 5-Fluorouracil Revisited. J. Chem. Thermodyn. 2014, 75, 106-115. [CrossRef]

407. Notario, R.; Roux, M.V.; Ros, F.; Emel'yanenko, V.N.; Zaitsau, D.H.; Verevkin, S.P. Thermochemistry of 1,3-Diethylbarbituric and 1,3-Diethyl-2-Thiobarbituric Acids: Experimental and Computational Study. J. Chem. Thermodyn. 2014, 77, 151-158. [CrossRef]

408. Xiao, S.-X.; Li, A.-T.; Li, X.; Li, C.-H.; Xiao, H.-Y.; Huang, S.; Chen, Q.-S.; Ye, L.-J.; Li, Q.-G. The Research on Formation Enthalpy of Phenanthroline Monohydrate and Its Influence on the Growth Metabolism of E. coli by Microcalorimetry. J. Therm. Anal. Calorim. 2014, 115, 2211-2217. [CrossRef]

409. Szterner, P.; Galvão, T.L.P.; Amaral, L.M.P.F.; Ribeiro da Silva, M.D.M.C.; Ribeiro da Silva, M.A.V. 5-Isopropylbarbituric and 2-Thiobarbituric Acids: An Experimental and Computational Study. Thermochim. Acta 2016, 625, 36-46. [CrossRef]

410. Carvalho, T.M.T.; Amaral, L.M.P.F.; Morais, V.M.F.; Ribeiro da Silva, M.D.M.C. Experimental and Computational Energetic Study of 1-R-2-Phenylindole $\left(\mathrm{R}=\mathrm{H}, \mathrm{CH}_{3}, \mathrm{C}_{2} \mathrm{H}_{5}\right)$. J. Chem. Thermodyn. 2015, 85, 129-140. [CrossRef]

411. Amaral, L.M.P.F.; Szterner, P.; Morais, V.M.F.; Ribeiro da Silva, M.D.M.C.; Ribeiro da Silva, M.A.V. Experimental and Computational Thermochemical Studies of 6-Azauracil Derivatives. J. Chem. Thermodyn. 2016, 96, 93-103. [CrossRef]

412. Ledo, J.M.; Camarillo, E.A.; Flores, H.; Ramos, F.; Rojas, A. Energies of Combustion and Enthalpies of Formation of 5-Methyl-5Phenylhydantoin and 5,5-Diphenylhydantoin. J. Anal. Calorim. 2016, 123, 2391-2396. [CrossRef]

413. Silva, A.L.R.; Ribeiro da Silva, M.A.V. Energetic, Structural and Tautomeric Analysis of 2-Mercaptobenzimidazole. An Experimental and Computational Approach. J. Therm. Anal. Calorim. 2017, 129, 1679-1688. [CrossRef]

414. Kazakov, A.I.; Kurochkina, L.S.; Nabatova, A.V.; Lempert, D.B.; Dalinger, I.L.; Kormanov, A.V.; Serushkina, O.V.; Sheremetev, A.B. Pyrazolyltetrazoles-A High-Enthalpy Backbone for Designing High-Energy Compounds: An Experimental Study of the Enthalpy of Formation. Dokl. Phys. Chem. 2018, 478, 15-18. [CrossRef]

415. Emel'yanenko, V.N.; Zaitsau, D.H.; Verevkin, S.P. Thermochemical Properties of Xanthine and Hypoxanthine Revisited. J. Chem. Eng. Data 2017, 62, 2606-2609. [CrossRef]

416. Mendoza-Ruiz, E.A.; Mentado-Morales, J.; Flores-Segura, H. Standard Molar Enthalpies of Formation and Phase Changes of Tetra-Nphenylbenzidine and 4,4'-Bis (N-Carbazolyl)-1,1'-Biphenyl. J. Therm. Anal. Calorim. 2018, 135, 2337-2345 . [CrossRef]

417. Perdomo, G.; Flores, H.; Ramos, F.; Notario, R.; Freitas, V.L.S.; Ribeiro da Silva, M.D.M.C.; Camarillo, E.A.; Dávalos, J.Z. Thermochemistry of R-SH Group in Gaseous Phase: Experimental and Theoretical Studies of Three Sulfur Imidazole Derivatives. J. Chem. Thermodyn. 2018, 122, 65-72. [CrossRef]

418. Emelyanenko, V.N.; Zaitsau, D.H.; Pimerzin, A.A.; Verevkin, S.P. N-ph N-Phenyl-Carbazole as a Potential Liquid Organic Hydrogen Carrier: Thermochemical and Computational Studyenyl-Carbazole as a Potential Liquid Organic Hydrogen Carrier: Thermochemical and Computational Study. J. Chem. Thermodyn. 2019, 132, 122-128. [CrossRef]

419. Orozco-Guareno, E.; Campos, J.B.; Barcena-Soto, M.; Zuniga-Gutierrez, B. Enthalpy of Formation for Indazoles (Indazole, 1H-Indazole-3-Carboxylic Acid, 1H-Indazole-5-Carboxylic Acid, 1H-Indazole-6-Carboxylic Acid and 1-Methyl-1H-Indazole-6Carboxylic Methyl Ester): Experimental and Theoretical Studies. J. Therm. Anal. Calorim. 2019, 141, 819-828 . [CrossRef]

420. Amaral, L.M.P.F.; Szterner, P.; Morais, V.M.F.; Ribeiro da Silva, M.D.M.C.; Ribeiro da Silva, M.A.V. Energetic Characterization of Uracil Derivatives: Orotic and Isoorotic Acids. Thermochim. Acta 2020, 683, 178474. [CrossRef]

421. Salomon-Santiago, C.; Perdomo, G.; Flores-Segura, H.; Notario, R.; Orozco-Guareno, E. Experimental and Theoretical Thermochemical Studies of Imidazole, Imidazole-2-Carboxaldehyde and 2-Aminobenzimidazole. Thermochim. Acta 2020, $693,178756$. [CrossRef] 
422. Konnova, M.E.; Li, S.; Bösmann, A.; Müller, K.; Wasserscheid, P.; Andreeva, I.V.; Turovtzev, V.V.; Zaitsau, D.H.; Pimerzin, A.A.; Verevkin, S.P. Thermochemical Properties and Dehydrogenation Thermodynamics of Indole Derivates. Ind. Eng. Chem. Res. 2020, 59, 20539-20550. [CrossRef]

423. Konkova, T.S.; Matyushin, Y.N.; Miroshnichenko, E.A.; Vorobev, A.B.; Palysaeva, N.V.; Sheremetev, A.B. Thermochemical Properties of $[1,2,4]$ Triazolo[4,3-b]-[1,2,4,5]Tetrazine Derivatives. Russ. J. Phys. Chem. B 2020, 14, 69-72. [CrossRef]

424. Acree, W.E., Jr.; Bott, S.G.; Tucker, S.A.; Ribeiro da Silva, M.A.V.; Matos, M.A.R.; Pilcher, G. Enthalpies of Combustion of 4-Methoxybenzofurazan, 4-Methoxybenzofurazan-1-Oxide, 4-Methylbenzofurazan-1-Oxide, 4-Chlorobenzofurazan-1-Oxid, and 3-Nitro-Benzofurazan-1-Oxide: The Dissociation Enthalpies of the N-O Bonds. J. Chem. Thermodyn. 1996, 28, 673-683. [CrossRef]

425. Verevkin, S.P. Thermochemistry of Amines: Strain in Six-Membered Rings from Experimental Standard Molar Enthalpies of Formation of Morpholines and Piperazines. J. Chem. Thermodyn. 1998, 30, 1069-1079. [CrossRef]

426. Korepin, A.G.; Kazakov, A.I.; Plishkin, N.A.; Ivanova, O.G.; Kurochkina, L.S.; Garanin, V.A.; Kosilko, V.P.; Nesterenko, D.A. Standard Enthalpies of Formation of Some N-Spiranes. Russ. Chem. Bull. 2011, 60, 1810-1813. [CrossRef]

427. Silva, A.L.R.; Cimas, A.; Ribeiro da Silva, M.D.M.C. Experimental and Computational Thermochemical Studies of Benzoxazole and Two Chlorobenzoxadole Derivatives. J. Chem. Thermodyn. 2013, 57, 212-219. [CrossRef]

428. Santos, A.F.L.O.M.; Silva, A.L.R.; Santiago, O.D.F.; Gonçalves, J.M.; Pandey, S.; Acree, W.E., Jr.; Ribeiro da Silva, M.D.M.C. Thermochemical Properties of 4-N,N-Dialkylamino-7-Nitrobenzofurazan Derivatives (Alkyl = Methyl, Ethyl). J. Chem. Thermodyn. 2014, 73, 62-68. [CrossRef]

429. Li, Y.-F.; Zhai, L.; Xu, K.-Z.; Song, J.-R.; Zhao, F.-Q. Energies of Combustion and Specific Heat Capacities of Diaminofurazan, Dinitrofurazan and Diaminoazofurazan. Chin. J. Energ. Mater. 2016, 24, 838-841. [CrossRef]

430. Flores, H.; Ledo, J.M.; Hernández-Pérez, J.M.; Camarillo, E.A.; Sandoval-Lira, J.; Amador, M.P. Thermochemical and Theoretical Study of 2-Oxazolidinone and 3-Acetyl-2-Oxazolidinone. J. Chem. Thermodyn. 2016, 102, 386-391. [CrossRef]

431. Freitas, V.L.S.; Silva, C.A.O.; Paiva, M.A.T.; Ribeiro da Silva, M.A.V. Energetic Effects of Alkyl Groups (Methyl and Ethyl) on the Nitrogen of the Morpholine Structure. J. Therm. Anal. Calorim. 2017, 130, 485-496. [CrossRef]

432. Perdomo, G.; Flores, H.; Notario, R.; Camarillo, E.A.; Amador, M.P. Enthalpies of Formation of Four Isoxazole Derivatives in the Solid and Gas Phases: Application to the Study of Chemical Equilibria. Struct. Chem. 2017, 28, 1111-1123. [CrossRef]

433. Freitas, V.L.S.; Silva, C.A.O.; Ribeiro da Silva, M.D.M.C. Energetic vs. Structural Effects of Aminoalkyl Substituents in the Morpholine. J. Chem. Thermodyn. 2018, 122, 95-101. [CrossRef]

434. Miranda, M.S.; Matos, M.A.R.; Morais, V.M.F.; Liebman, J.F. Combined Experimental and Computational Study on the Energetics of 1,2-Benzisothiazol-3(2H)-One and 1,4-Benzothiazin-3(2H, 4H)-One. J. Chem. Thermodyn. 2011, 43, 635-644. [CrossRef]

435. Miranda, M.S.; Matos, M.A.R.; Morais, V.M.F.; Liebman, J.F. 2,1,3-Benzothiadiazole: Study of its Structure, Energetics and Aromaticity. J. Chem. Thermodyn. 2012, 50, 30-36. [CrossRef]

436. Silva, A.L.R.; Cimas, A.; Ribeiro da Silva, M.D.M.C. Energetic Study of Benzothiazole and Two Methylbenzothiazole Derivatives: Calorimetric and Computational Approaches. J. Chem. Thermodyn. 2014, 73, 3-11. [CrossRef]

437. Camarillo, E.A.; Mentado, J.; Flores, H.; Hernández-Pérez, J.M. Standard Enthalpies of Formation of 2-Aminobenzothiazoles in the Crystalline Phase by Rotating-Bomb Combustion Calorimetry. J. Chem. Thermodyn. 2014, 73, 269-273. [CrossRef]

438. Silva, A.L.R.; Monte, M.J.S.; Morais, V.M.F.; Ribeiro da Silva, M.D.M.C. Thermodynamic Study of 2-Aminothiazole and 2Aminobenzothiazole: Experimental and Computational Approaches. J. Chem. Thermodyn. 2014, 74, 67-77. [CrossRef]

439. Jorge, N.L.; Leiva, L.C.A.; Castellanos, M.G.; Gómez Vara, M.E.; Cafferata, L.F.R.; Castro, E.A. Experimental and Theoretical Study of the Enthalpy of Formation of 3,6-Diphenyl-1,2,4,5-Tetroxane Molecule. Sci. World J. 2002, 2, 455-460. [CrossRef] [PubMed]

440. Ribeiro da Silva, M.A.V.; Amaral, L.M.P.F. Standard Molar Enthalpies of Formation of 2-Furancarbonitrile, 2-Acetylfuran, and 3-Furaldehyde. J. Chem. Thermodyn. 2009, 41, 26-29. [CrossRef]

441. Matos, M.A.R.; Sousa, C.C.S.; Morais, V.M.F. Experimental and Computational Thermochemistry of the Isomers: CHROMANONE, 3-Isochromanone, and Dihydrocoumarin. J. Chem. Thermodyn. 2009, 41, 308-314. [CrossRef]

442. Ribeiro da Silva, M.A.V.; Amaral, L.M.P.F. Standard Molar Enthalpies of Formation of Some Vinylfuran Derivatives. J. Chem. Thermodyn. 2009, 41, 349-354. [CrossRef]

443. Sousa, C.C.S.; Matos, M.A.R.; Morais, V.M.F. Energetics of Flavone and Flavanone. J. Chem. Thermodyn. 2009, 41, 1408-1412. [CrossRef]

444. Ribeiro da Silva, M.A.V.; Santos, A.F.L.O.M.; Amaral, L.M.P.F. A Calorimetric and Computational Study on the Thermochemistry of 2-(5H)-Furanone and 2-(5H)-Thiophenone. J. Chem. Thermodyn. 2010, 42, 564-570. [CrossRef]

445. Freitas, V.L.S.; Gomes, J.R.B.; Ribeiro da Silva, M.D.M.C. Energetic Effects of Ether and Ketone Functional Groups in 9,10Dihydroanthracene Compound. J. Chem. Thermodyn. 2010, 42, 1248-1254. [CrossRef]

446. Sousa, C.C.S.; Morais, V.M.F.; Matos, M.A.R. Energetics of the Isomers: 3- and 4-Hydroxycoumarin. J. Chem. Thermodyn. 2010, 42, 1372-1378. [CrossRef]

447. Ribeiro da Silva, M.A.V.; Amaral, L.M.P.F. Thermochemical Study of 2,5-Dimethyl-3-Furancarboxylic Acid, 4,5-Dimethyl-2Furaldehyde, and 3-Acetyl-2,5-Dimethylfuran. J. Chem. Thermodyn. 2011, 43, 1-8. [CrossRef]

448. Sousa, C.C.S.; Matos, M.A.R.; Morais, V.M.F. When Theory and Experiment Hold Hands: The Thermochemistry of $\gamma$-Pyrone Derivatives. J. Chem. Thermodyn. 2011, 43, 1159-1163. [CrossRef] 
449. Amador, P.; Pineda, B.; López, A.; Flores, H. Standard Molar Enthalpies of Formation in the Crystalline Phase of 7-Hydroxy4-Methylcoumarin, 7-Ethoxy-4-Methylcoumarin, and 6-Methoxy-4-Methylcoumarin. J. Chem. Thermodyn. 2011, 43, 1414-1416. [CrossRef]

450. Sousa, C.C.S.; Morais, V.M.F.; Matos, M.A.R. Experimental and Computational Thermochemistry of 6,7-Dihydro-4(5H)Benzofuranone. J. Chem. Thermodyn. 2013, 56, 83-88. [CrossRef]

451. Dibrivnyi, V.; Marshalek, A.; Sobechko, I.; Horak, Y.; Obushak, M.; Velychkivska, N.; Goshko, L. Thermodynamic Properties of Some Isomeric 5-(Nitrophenyl)-Furyl-2 Derivatives. BMC Chem. 2019, 13, 1-11. [CrossRef]

452. Pihlaja, K.; Kivelä, H.; Vainiotalo, P.; Steele, W.V. Enthalpies of Combustion and Formation of Severely Crowded MethylSubstituted 1,3-Dioxanes. The Magnitudes of 2,4- and 4,6-Diaxial Me, Me-Interactions and the Chair-2,5-Twist Energy Difference. Molecules 2020, 25, 2762. [CrossRef]

453. Ribeiro da Silva, M.A.V.; Santos, A.F.L.O.M. Thermochemical Study of 2- and 3-Alkyl Substituted Thiophenes: Energetic-Structural Correlations. J. Therm. Anal. Calorim. 2007, 88, 7-17. [CrossRef]

454. Roux, M.V.R.; Temprado, M.; Jimenez, P.; Notario, R.; Chickos, J.S.; Santos, A.F.L.O.M.; Ribeiro da Silva, M.A.V. Thermochemistry of 2- and 3-Acetylthiophenes: Calorimetric and Computational Study. J. Phys. Chem. A 2007, 111, 11084-11092. [CrossRef]

455. Ribeiro da Silva, M.A.V.; Santos, A.F.L.O.M. Thermochemistry of Substituted Thiophenecarbonitrile Derivatives. J. Chem. Thermodyn. 2008, 40, 225-231. [CrossRef]

456. Ribeiro da Silva, M.A.V.; Santos, A.F.L.O.M. Experimental Study on the Thermochemistry of 2,5-Dimethylthiophene and its Acetyl Derivative. J. Chem. Thermodyn. 2008, 40, 1217-1221. [CrossRef]

457. Ribeiro da Silva, M.A.V.; Santos, A.F.L.O.M. Experimental Thermochemical Study of the Three Methyl Substituted 2Acetylthiophene Isomers. J. Chem. Thermodyn. 2008, 40, 1309-1313. [CrossRef]

458. Freitas, V.L.S.; Monte, M.J.S.; Santos, L.M.N.B.F.; Gomes, J.R.B.; Ribeiro da Silva, M.D.M.C. Energetic Studies and Phase Diagram of Thioxanthene. J. Phys. Chem. A 2009, 113, 12988-12994. [CrossRef]

459. Freitas, V.L.S.; Gomes, J.R.B.; Ribeiro da Silva, M.D.M.C. Revisiting Dibenzothiophene Thermochemical Data: Experimental and Computational Studies. J. Chem. Thermodyn. 2009, 41, 1199-1205. [CrossRef]

460. Ribeiro da Silva, M.A.V.; Santos, A.F.L.O.M. Experimental Thermochemical Study of 3-Acetyl-2-Methyl-5-Phenylthiophene. J. Chem. Thermodyn. 2010, 42, 128-133. [CrossRef]

461. Freitas, V.L.S.; Gomes, J.R.B.; Ribeiro da Silva, M.D.M.C. Molecular Energetics of 4-Methyldibenzothiophene: An Experimental study. J. Chem. Thermodyn. 2010, 42, 251-255. [CrossRef]

462. Gudino, R.; Torres, L.A.; Campos, M.; Santillan, R.L.; Farfan, N. The Standard Molar Enthalpies of Combustion and Sublimation of Benzothiazino-Benzothiazine and Benzoxazino-Benzoxazine. J. Chem. Thermodyn. 1997, 29, 565-574. [CrossRef]

463. Macnab, A.C.J.I. Measurement and Prediction of Enthalpies of Combustion and Formation of Oxygen and Nitrogen Heterocycles. Thermochim. Acta 2000, 344, 15-21.

464. Mentado, J.; Flores, H.; Amador, P. Combustion Energies and Formation Enthalpies of 2-SH-Benzazoles. J. Chem. Thermodyn. 2008, 40, 1106-1109. [CrossRef]

465. Flores, H.; Camarillo, E.A.; Mentado, J. Enthalpies of Combustion and Formation of 2-Acetylpyrrole, 2-Acetylfuran and 2Acetylthiophene. Thermochim. Acta 2009, 493, 76-79. [CrossRef]

466. Roux, M.V.; Temprado, M.; Jimenez, P.; Foces-Foces, C.; Parameswar, A.R.; Demchenko, A.V.; Chickos, J.S.; Deakyne, C.A.; Ludden, A.K.; Liebman, J.F. Experimental and Theoretical Study of the Structures and Enthalpies of Formation of the Synthetic Reagents 1,3-Thiazolidine-2-Thione and 1,3-Oxazolidine-2-Thione. J. Phys. Chem. A 2009, 113, 10772-10778. [CrossRef]

467. Roux, M.V.; Temprado, M.; Jimenez, P.; Foces-Foces, C.; Parameswar, A.R.; Demchenko, A.V.; Chickos, J.S.; Deakyne, C.A.; Ludden, A.K.; Liebman, J.F. Experimental and Theoretical Study of the Structures and Enthalpies of Formation of 3H-1,3Benzoxazole-2-Thione, 3H-1,3-Benzothiazole-2-Thione, and Their Tautomers. J. Phys. Chem. A 2010, 114, 6336-6341. [CrossRef] [PubMed]

468. Ramos, F.; Flores, H.; Rojas, A.; Hernández-Pérez, J.M.; Camarillo, E.A.; Amador, M.P. Experimental and Computational Thermochemical Study of Benzofuran, Benzothiophen and Indole Derivatives. J. Chem. Thermodyn. 2016, 97, 297-306. [CrossRef]

469. Silva, A.L.R.; Matos, M.A.R.; Morais, V.M.F.; Ribeiro da Silva, M.D.M.C. Thermochemical and Conformational Study of Optical Active Phenylbenzazole Derivatives. J. Chem. Thermodyn. 2018, 116, 7-20. [CrossRef]

470. Silva, A.L.R.; Morais, V.M.F.; Ribeiro da Silva, M.D.M.C. Thermodynamic Properties of Naphthoxazole and Naphthothiazole Derivatives: Experimental and Computational Studies. J. Chem. Thermodyn. 2018, 127, 45-55. [CrossRef]

471. Silva, A.L.R.; Ribeiro da Silva, M.D.M.C. Effects of the Functional Groups Amino and Nitro on the Reactivity of Benzoxazoles and Comparison with Homologous Benzothiazoles. J. Phys. Org. Chem. 2020, 34, e4118. [CrossRef]

472. Ribeiro da Silva, M.A.V.; Reis, A.M.V.; Pilcher, G. Enthalpies of Formation of Crystalline DialkylammoniumdialkylDithiocarbamates: Alkyl = Ethyl, n-Propyl, $i$-Propyl, $n$-Butyl, and $i$-Butyl. J. Chem. Thermodyn. 1987, 19, 837-844. [CrossRef]

473. Zhang, Z.-H.; Guan, W.; Yang, J.-Z.; Tan, Z.-C.; Sun, L.-X. The Standard Molar Enthalpy of Formation of Room Temperature Ionic Liquid EMIES. Acta Phys.-Chim. Sin. 2004, 20, 1469-1471. [CrossRef]

474. Gao, Y.; Arritt, S.W.; Twamley, B.; Shreeve, J.M. Guanidinium-Based Ionic Liquids. Inorg. Chem. 2005, 44, 1704-1712. [CrossRef]

475. Xue, H.; Gao, Y.; Twamley, B.; Shreeve, J.M. Energetic Azolium Azolate Salts. Inorg. Chem. 2005, 44, 5068-5072. [CrossRef]

476. Zhang, Z.-H.; Tan, Z.-C.; Sun, L.-X.; Zhen, Y.-J.; Lv, X.-C.; Shi, Q. Thermodynamic Investigation of Room Temperature Ionic Liquid: The Heat Capacity and Standard Enthalpy of Formation of EMIES. Thermochim. Acta 2006, 447, 141-146. [CrossRef] 
477. Zhang, Z.H.; Tan, Z.C.; Li, Y.S.; Sun, L.X. Thermodynamic Investigation of Room Temperature Ionic Liquid: Heat Capacity and Thermodynamic Functions of BMIBF4. J. Therm. Anal. Calorim. 2006, 85, 551-557. [CrossRef]

478. Emel'yanenko, V.N.; Verevkin, S.P.; Heintz, A. The Gaseous Enthalpy of Formation of the Ionic Liquid 1-Butyl-3Methylimidazolium Dicyanamide from Combustion Calorimetry, Vapor Pressure Measurements, and Ab Initio Calculations. J. Am. Chem. Soc. 2007, 129, 3930-3937. [CrossRef]

479. Emelyanenko, V.N.; Verevkin, S.P.; Heintz, A.; Schick, C. Ionic Liquids. Combination of Combustion Calorimetry with High-Level Quantum Chemical Calculations for Deriving Vaporization Enthalpies. J. Phys. Chem. B 2008, 112, 8095-8098. [CrossRef]

480. Emel'yanenko, V.N.; Verevkin, S.P.; Heintz, A.; Corfield, J.-A.; Deyko, A.; Lovelock, K.R.J.; Licence, P.; Jones, R.G. PyrrolidiniumBased Ionic Liquids. 1-Butyl-1-Methyl Pyrrolidinium Dicyanoamide: Thermochemical Measurement, Mass Spectrometry, and Ab Initio Calculations. J. Phys. Chem. B 2008, 112, 11734-11742. [CrossRef] [PubMed]

481. Guan, W.; Fang, D.-W.; Sun, Y.-C.; Tong, J.; Yang, J.-Z. Standard Molar Enthalpy of Combustion and Formation of Ionic Liquid Alkylimidazolium Chloride. Acta Chim. Sin. 2008, 66, 1833-1836.

482. Strechan, A.A.; Kabo, A.G.; Paulechka, Y.U.; Blokhin, G.J.; Kabo, G.J.; Shaplov, A.S.; Lozinskaya, E.I. Thermochemical Properties of 1-Butyl-3-Methylimidazolium Nitrate. Thermochim. Acta 2008, 474, 25-31. [CrossRef]

483. Emel'yanenko, V.N.; Verevkin, S.P.; Heintz, A.; Voss, K.; Schulz, A. Imidazolium-Based Ionic Liquids. 1-Methyl Imidazolium Nitrate: Thermochemical Measurements and Ab Initio Calculations. J. Phys. Chem. B 2009, 113, 9871-9876. [CrossRef]

484. Liu, Y.-P.; Di, Y.-Y.; Dan, W.-Y.; He, D.-H.; Kong, Y.-X.; Yang, W.-W. Lattice Potential Energy and Standard Molar Enthalpy in the Formation of 1-Dodecylamine Hydrobromide (1- $\left.\mathrm{C}_{12} \mathrm{H}_{25} \mathrm{NH}_{3} \cdot \mathrm{Br}\right)(\mathrm{s})$. Chin. Phys. B 2011, 20, 028202. [CrossRef]

485. Wei, X.-1.; Fu, S.-Z.; Wei, Z.-B.; Di, Y.-Y.; Liu, J.-Q.; Sun, D.-Z.; Yin, B.-L.; Zhang, S.-H. Standard Molar Enthalpy of Combustion and Formation of Ionic Liquid 1-Alkylimidazolium Bromine. Glob. J. Phys. Chem. 2011, 2, 287-293.

486. Zaitsau, D.H.; Emel'yanenko, V.N.; Verevkin, S.P.; Heintz, A. Sulfur-Containing Ionic Liquids. Rotating-Bomb Combustion Calorimetry and First-Principles Calculations for 1-Ethyl-3-Methylimidazolium Thiocyanate. J. Chem. Eng. Data 2010, 55, 5896-5899. [CrossRef]

487. Verevkin, S.P.; Emelyanenko, V.N.; Zaitsau, D.H.; Heintz, A.; Muzny, C.D.; Frenkel, M. Thermochemistry of Imidazolium-Based Ionic Liquids: Experiment and First-Principles Calculations. Phys. Chem. Chem. Phys. 2010, 12, 14994-15000. [CrossRef] [PubMed]

488. Gao, H.; Shreeve, J.M. Azole-Based Energetic Salts. Chem. Rev. 2011, 111, 7377-7436. [CrossRef] [PubMed]

489. Zhu, J.-F.; He, L.; Zhang, L.; Huang, M.; Tao, G.-H. Experimental and Theoretical Enthalpies of Formation of Glycine-Based Sulfate/Bisulfate Amino Acid Ionic Liquids. J. Phys. Chem. B 2012, 116, 113-119. [CrossRef] [PubMed]

490. Emel'yanenko, V.N.; Verevkin, S.P.; Heintz, A. Pyridinium Based Ionic Liquids. N-Butyl-3-Methyl-Pyridinium Dicyanoamide: Thermochemical Measurement and First-Principles Calculations. Thermochim. Acta 2011, 514, 28-31. [CrossRef]

491. Emel'yanenko, V.N.; Zaitsau, D.H.; Verevkin, S.P.; Heintz, A. Imidazolium Based Ionic Liquids. 1-Ethanol-3-Methyl-Imidazolium Dicyanoamide: Thermochemical Measurement and First-Principles Calculations. Thermochim. Acta 2011, 518, 107-110. [CrossRef]

492. Guan, W.; Wang, C.; Wang, Z.; Chen, S.; Gao, S. Thermochemistry on 1-Methyl-3-Ethylimidazolium Valine Ionic Liquid [C2mim][Val]. Acta Chim. Sin. 2011, 69, 1280-1286.

493. Verevkin, S.P.; Zaitsau, D.H.; Emel'yanenko, V.N.; Paulechka, Y.U.; Blokhin, A.V.; Bazyleva, A.B.; Kabo, G.J. Thermodynamics of Ionic Liquids Precursors: 1-Methylimidazole. J. Phys. Chem. B 2011, 115, 4404-4411. [CrossRef]

494. Emel'yanenko, V.N.; Zaitsau, D.H.; Verevkin, S.P.; Heintz, A.; Voss, K.; Schulz, A. Vaporization and Formation Enthalpies of 1-Alkyl-3-Methylimidazolium Tricyanomethanides. J. Phys. Chem. B 2011, 115, 11712-11717. [CrossRef]

495. Verevkin, S.P.; Emel'yanenko, V.N.; Krossing, I.; Kalb, R. Thermochemistry of Ammonium Based Ionic Liquids: Tetra-Alkyl Ammonium Nitrates-Experiments and Computations. J. Chem. Thermodyn. 2012, 51, 107-113. [CrossRef]

496. Zaitsau, D.H.; Yermalayeu, A.V.; Emel'yanenko, V.N.; Heintz, A.; Verevkin, S.P.; Schick, C.; Berdzinski, S.; Strehmel, V. StructureProperty Relationships in ILs: Vaporization Enthalpies of Pyrrolidinium Based Ionic Liquids. J. Mol. Liq. 2014, 192, 171-176. [CrossRef]

497. Yermalayeu, A.V.; Zaitsau, D.H.; Emel'yanenko, V.N.; Verevkin, S.P. Thermochemistry of Ammonium Based Ionic Liquids: Thiocyanates-Experiments and Computations. J. Solut. Chem. 2015, 44, 754-768. [CrossRef]

498. Tian, T.; Hu, X.; Guan, P.; Wang, S.; Ding, X. Density and Thermodynamic Performance of Energetic Ionic Liquids Based on 1-Alkyl/Esteryl-4-Amino-1,2,4-Triazolium. J. Mol. Liq. 2017, 248, 70-80. [CrossRef]

499. Carpenter, G.A.; Zimmer, M.F.; Baroody, E.E.; Robb, R.A. Enthalpy of Formation of N,N,N-Trifluorohexaneamidine, (2-Fluoro-2,2dinitroethyl)acrylate, 2,4-Dinitrophenoxyethanol, and Diisobutylazelate. J. Chem. Eng. Data 1971, 16, 46-49.

500. Lebedev, B.V. Thermodynamics of Diphenylcarbodiimide. Zhum. Obshch. Khim. 1984, 54, 417-424.

501. Imamura, A.; Takahashi, K.; Murata, S.; Sakiyama, M. Standard Enthalpies of Formation of Trimethyl Cyanurate, Malonamide, and 1,3-Dimethyluracil. J. Chem. Thermodyn. 1989, 21, 231-246. [CrossRef]

502. Steele, W.V.; Chirico, R.D.; Knipmeyer, S.E.; Nguyen, A.; Smith, N.K.; Tasker, I.R. Thermodynamic Properties and IdealGas Enthalpies of Formation for Cyclohexene, Phthalan (2,5-Dihydrobenzo-3,4-Furan), Isoxazole, Octylamine, Dioctylamine, Trioctylamine, Phenyl Isocyanate, and 1,4,5,6-Tetrahydropyrimidine. J. Chem. Eng. Data 1996, 41, 1269-1284. [CrossRef]

503. Steele, W.V.; Chirico, R.D.; Knipmeyer, S.E.; Nguyen, A.; Smith, N.K. Thermodynamic Properties and Ideal-Gas Enthalpies of Formation for Dicyclohexyl Sulfide, Diethylenetriamine, Di- $N$-Octyl Sulfide, Dimethyl Carbonate, Piperazine, Hexachloroprop1-Ene, Tetrakis(Dimethylamino)Ethylene, N,Nф-Bis-(2-Hydroxyethyl)Ethylenediamine, and 1,2,4-Triazolo[1,5-a]Pyrimidine. J. Chem. Eng. Data 1997, 42, 1037-1052. 
504. Boerio-Goates, J.; Francis, M.R.; Goldberg, R.N.; Ribeiro da Silva, M.A.V.; Ribeiro da Silva, M.D.M.C.; Tewari, Y.B. Thermochemistry of Adenosine. J. Chem. Thermodyn. 2001, 33, 929-947. [CrossRef]

505. Monte, M.J.S.; Hillesheim, D.M. Thermodynamic Study on the Sublimation of 1,2-Diphenylethane and of 3-Phenylpropiolic Acid. J. Chem. Thermodyn. 2001, 33, 849-857. [CrossRef]

506. Ribeiro da Silva, M.D.M.C.; Gonçalves, J.M.; Silva, A.I.R.; Silva, A.M.R.O.A.; Oliveira, P.C.F.C.; Ribeiro da Silva, M.A.V. Experimental Study of the Energetics of Tetradentate $\mathrm{N}_{2} \mathrm{O}_{2}$ Schiff Bases Derived from Salicylaldehyde. Thermochim. Acta 2004, 420, 67-71. [CrossRef]

507. Boerio-Goates, J.; Hopkins, S.D.; Monteiro, R.A.R.; Ribeiro da Silva, M.D.M.C.; Ribeiro da Silva, M.A.V.; Goldberg, R.N. Thermochemistry of Inosine. J. Chem. Thermodyn. 2005, 37, 1239-1249. [CrossRef]

508. Ribeiro da Silva, M.A.V.; Santos, L.M.N.B.F.; Schröder, B. Thermochemical Studies of Two N-(Diethylaminothiocarbonyl)Benzimido Derivatives. J. Chem. Thermodyn. 2006, 38, 1455-1460. [CrossRef]

509. Di, Y.-Y.; Ye, C.-T.; Tan, Z.-C.; Zhang, G.-D. Low-Temperature Heat Capacity and Standard Molar Enthalpy of Formation of Crystalline (S)-(+)-Ibuprofen $\left(\mathrm{C}_{13} \mathrm{H}_{18} \mathrm{O}_{2}\right)$ (s). Ind. J. Chem. 2007, 46, 947-951.

510. Matos, M.A.R.; Miranda, M.S.; Morais, V.M.F.; Liebman, J.F. Saccharin: A Combined Experimental and Computational Thermochemical Investigation of a Sweetener and Sulfonamide. Mol. Phys. 2005, 103, 221-228. [CrossRef]

511. Ribeiro da Silva, M.D.M.C.; Araújo, N.R.M.; Silva, A.L.R.; da Silva, L.C.M.; Barros, N.P.S.M.; Goncalves, J.M.; Ribeiro da Silva, M.A.V. Three $\mathrm{N}_{2} \mathrm{O}_{2}$ Ligands Derived from the Condensation of 1,2-Cyclhexanediamine with Salicylaldehyde, Acetylacetone and Benzoylacetone: A New Contribution to the Energetical Characterization of Schiff Bases. J. Therm. Anal. Calorim. 2007, 87, 291-296. [CrossRef]

512. Hou, H.; Dong, J.; Liu, Y. Standard Molar Enthalpy of Formation of Morin Studied by Rotating-Bomb Combustion Calorimetry. J. Nat. Sci. 2008, 13, 103-106. [CrossRef]

513. Surov, A.O.; Perlovich, G.L.; Emel'yanenko, V.N.; Verevkin, S.P. Thermochemistry of Drugs. Experimental and First-Principles Study of Fenamates. J. Chem. Eng. Data 2011, 56, 4325-4433. [CrossRef]

514. Lima, C.F.R.A.C.; Rocha, M.A.A.; Gomes, L.R.; Low, J.N.; Silva, A.M.S.; Santos, L.M.N.B.F. Experimental Support for the Role of Dispersion Forces in Aromatic Interactions. Chem. Eur. J. 2012, 18, 8934-8943. [CrossRef]

515. Ovchinnikov, V.V. Thermochemistry of Heteroatomic Compounds: Enthalpy of Combustion of Organic Compounds of Group I-VII Elements. Dokl. Phys. Chem. 2012, 443, 49-52. [CrossRef]

516. Oliveira, J.A.S.A.; Calvinho, M.M.; Notario, R.; Monte, M.J.S.; Ribeiro da Silva, M.D.M.C. A Combined Experimental and Computational Thermodynamic Study of Fluorene-9-Methanol and Fluorene-9-Carboxylic Acid. J. Chem. Thermodyn. 2013, 62, 222-230. [CrossRef]

517. Yu, X.; Zhou, C.-R.; Han, X.-W.; Li, G.-P. Study on Thermodynamic Properties of Glyphosate by Oxygen-Bomb Calorimeter and DSC. J. Therm. Anal. Calorim. 2013, 111, 943-949. [CrossRef]

518. Li, X.; Jiang, J.-H.; Gu, H.-W.; Xiao, S.-X.; Li, C.-H.; Ye, L.-J.; Li, X.; Li, Q.-G.; Xu, F.; Sun, L.-X. Calorimetric Determination of the Standard Molar Enthalpies of Formation of o-Vanillin and Trimethoprim. J. Therm. Anal. Calorim. 2015, 119, 721-726. [CrossRef]

519. Shen, C.; Li, W.; Zhou, C. Investigation on Molar Heat Capacity, Standard Molar Enthalpy of Combustion for Guaiacol and Acetyl Guaiacol Ester. Chin. J. Chem. Eng. 2016, 24, 1772-1778. [CrossRef]

520. Emel'yanenko, V.N.; Yermalayeu, A.V.; Voges, M.; Held, C.; Sadowski, G.; Verevkin, S.P. Thermodynamics of a Model Biological Reaction: A Comprehensive Combined Experimental and Theoretical Study. Fluid Phase Equil. 2016, 422, 99-110. [CrossRef]

521. Knyazev, A.V.; Emel'yanenko, V.N.; Smirnova, N.N.; Zaitsau, D.H.; Stepanova, O.V.; Markin, A.V.; Gusarova, E.V.; Knyazeva, S.S.; Verevkin, S.P. Comprehensive Thermodynamic Study of Methylprednisolone. J. Chem. Thermodyn. 2017, 107, 37-41. [CrossRef]

522. Maksimuk, Y.; Ponomarev, D.; Sushkova, A.; Krouk, V.; Vasarenko, I.; Antonava, Z. Standard Molar Enthalpy of Formation of Vanillin. J. Therm. Anal. Calorim. 2018, 131, 1721-1733. [CrossRef]

523. Szterner, P.; Amaral, L.M.P.F.; Morais, V.M.F.; Ribeiro da Silva, M.D.M.C.; Ribeiro da Silva, M.A.V. Energetic Characterization of a Bioactive Compound: Uridine. J. Chem. Thermodyn. 2018, 124, 90-97. [CrossRef]

524. Siewert, R.; Zaitsau, D.H.; Emel'yanenko, V.N.; Verevkin, S.P. Biomass Valorization: Thermodynamics of the Guerbet Condensation Reaction. J. Chem. Eng. Data 2019, 64, 4904-4914. [CrossRef]

525. Silva, A.L.R.; Goncalves, J.M.; Morais, V.M.F.; Ribeiro da Silva, M.D.M.C. Energetics of Tetradentate $\mathrm{N}_{2} \mathrm{O}_{2}$ Schiff Bases Containing Different Alkyldiimine Brigdes. Thermochim. Acta 2021, 695, 178817. [CrossRef]

526. Verevkin, S.P.; Konnova, M.E.; Turovtsev, V.V.; Riabchunova, A.V.; Pimerzin, A.A. Weaving a Network of Reliable Thermochemistry around Lignin Building Blocks: Methoxy-Phenols and Methoxy-Benzaldehydes. Ind. Eng. Chem. Res. 2020, 59, 22626-22639. [CrossRef]

527. Allen, F.H. The Cambridge Structural Database: A Quarter of a Million Crystal Structures and Rising. Acta Crystallogr. Sect. B Struct. Sci. 2002, 58, 380-388. [CrossRef]

528. Rau, H. Über die Fluoreszenz p-Substituierter Adsorbierter Azoverbindungen. Ber. Bunsenges. Phys. Chem. 1971, 75, 1343-1347. [CrossRef]

529. Yoshihiro, K.; Hohi, L.; Akio, K. Direct Evidence for the Site of Protonation of 4-Aminoazobenzene by Nitrogen-15 and Carbon-13 Nuclear Magnetic Resonance Spectroscopy. J. Phys. Chem. 1980, 84, 3417-3423. 
530. Kelemen, J.; Moss, S.; Sauter, H.; Winkler, T. Azo-Hydrazone Tautomerism in Azo Dyes. II. Raman, NMR and Mass Spectrometric Investigations of 1-Phenylazo-2-Naphthylamine and 1-Phenylazo-2-Naphthol Derivatives. Dyes Pigment. 1982, 3, 27-47. [CrossRef]

531. Kelemen, J. Azo-Hydrazone Tautomerism in Azo Dyes. I. A Comparative Study of 1-Phenylazo-2-Naphthol and 1-Phenylazo-2Naphthylamine Derivatives by Electronic Spectroscopy. Dyes Pigment. 1981, 2, 73-91. [CrossRef]

532. Reeves, R.L.; Kaiser, R.S. Selective Solvation of Hydrophobic Ions in Structured Solvents. Azo-Hydrazone Tautomerism of Azo dyes in Aqueous Organic Solvents. J. Org. Chem. 1970, 35, 3670-3675. [CrossRef]

533. Yatsenko, A.V. The Structures of Organic Molecules in Crystals: Simulations Using the Electro-Static Potential. Rus. Chem. Rev. 2005, 74, 521. [CrossRef]

534. Dudek, G.O.; Dudek, E.P. Spectroscopic Studies of Keto-Enol Equilibria. IX. $\mathrm{N}^{15}$-Substituted Anilides. J. Am. Chem. Soc. 1966, 88, 2407-2412. [CrossRef]

535. Hine, J.; Arata, K. Keto-Enol-Tautomerism. II. The Calorimetrical Determination of the Equilibrium Constants for Keto-Enol Tautomerism for Cyclohexanone and Acetone. Bull. Chem. Soc. Jpn. 1976, 49, 3089-3092. [CrossRef]

536. Hine, J.; Arata, K. Keto-Enol-Tautomerism. I. The Calorimetrical Determination of the Equilibrium Constants for Keto-Enol Tautomerism for Cyclopentanone. Bull. Chem. Soc. Jpn. 1976, 49, 3085-3088. [CrossRef]

537. Zhu, L.; Bozzelli, J.W. Kinetics and Thermochemistry for the Gas-Phase Keto-Enol Tauto-Merism of Phenol $\leftrightarrow$ 2,4Cyclohexadienone. J. Phys. Chem. 2003, 107, 3696-3703. [CrossRef]

538. Katritzky, A.R.; Szafran, M. AM1 Study of the Tautomerism of 2- and 4-Pyridones and Their Thio-Analogs. J. Mol. Struct. THEOCHEM 1989, 184, 179-192. [CrossRef]

539. Schlegel, H.B.; Gund, P.; Fluder, E.M. Tautomerization of Formamide, 2-Pyridone, and 4-Pyridone: An Ab Initio Study. J. Am. Chem. Soc. 1982, 104, 5347-5351. [CrossRef]

540. Moreno, M.; Miller, W.H. On the Tautomerization Reaction 2-Pyridone-2-Hydroxypyridine: An Ab Initio Study. Chem. Phys. Lett. 1990, 171, 475-479. [CrossRef]

541. Claus, A. CLXIII. Zur Kenntniss des Carbostyrils und Seiner Derivate, ein Beitrag zur Lösung der Tautomeriefrage. J. Prakt. Chem. 1896, 53, 325-334. [CrossRef]

542. Hartley, W.N.; Dobbie, F.R.S.; Dobbie, J.J. LXII-A Study of the Absorption Spectra of Isatin, Carbostyril, and Their Alkyl Derivatives in Relation to Tautomerism. J. Chem. Soc. Trans. 1899, 75, 640-661. [CrossRef]

543. Fabian, W.M.F.; Niederreiter, K.S.; Uray, G.; Stadlbauer, W. Substituent Effects on Absorption and Fluorescence Spectra of Carbostyrils. J. Mol. Struct. 1999, 477, 209-220. [CrossRef]

544. Allen, G.; Dwek, R.A. An nmr Study of Keto-Enol Tautomerism in $\beta$-Diketones. J. Chem. Soc. B 1966, 161-163. [CrossRef] 